UC-NRLF

||||||||||||||||||||||||||||

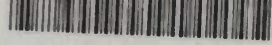

\$B 8 ㄹㄹ 


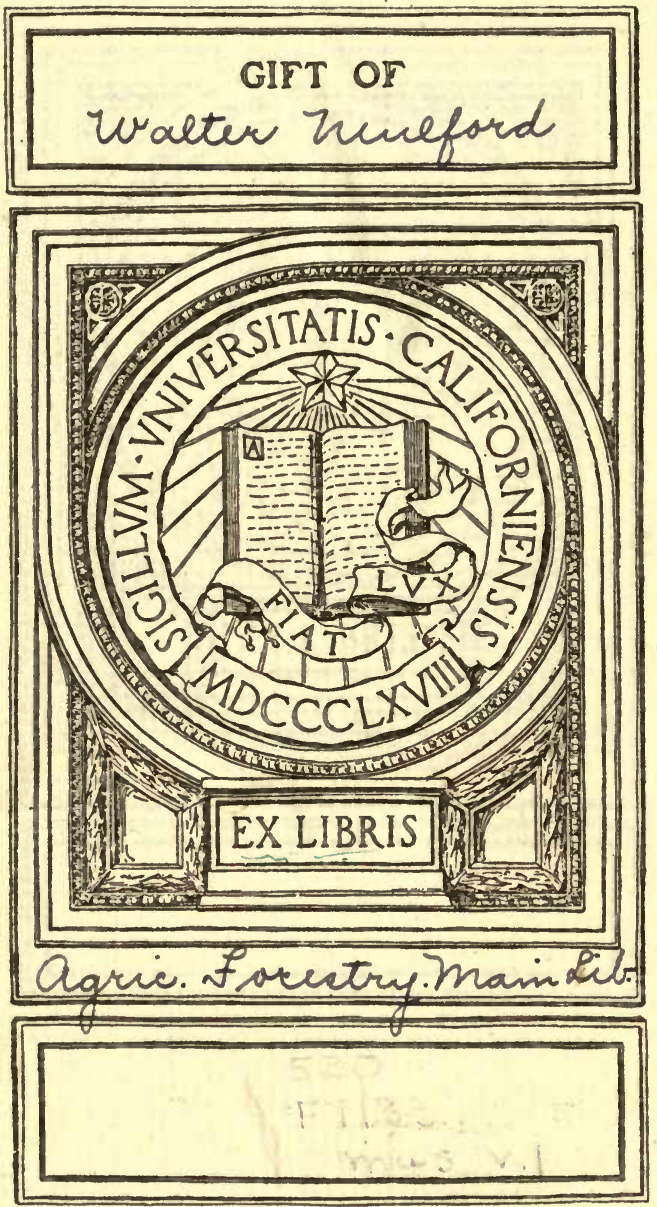




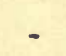



Paugheies on forcalies in Masodachoects.

\section{MASSACHUSETTS FORESTRY PAMPHLEMS}

\section{Vinellacuen VOT. I}

Forestry in Massachusetts, by Alfred Ake rman.

Bulletin No. 1. State Forester's Office.

Improvement Thinning, by Alfred Akerman. Bull.

No. 2. State Forester's Office.

Report of the Committee of 1905 to Consider the

Laws Relative to the Taxation of Forestuc.

Lands. State Forester's Office. Bull. No.3.

Practical Suggestions for the Massachusetts Iree

Planter, by R. C. Hawley. State Forester's Office. Bulletin No. 4.

Forest Fires, by Alfred Akerman. State Forester's Office. Bulletin No. 5.

Fourth Annual Report of the State Forester of Massachusetts. 1907. 10-33194

Fifth Annual Report of the State Forester of Nassachusetts. 1908. 
$S D 144$

$M 3 P 3$

U.I

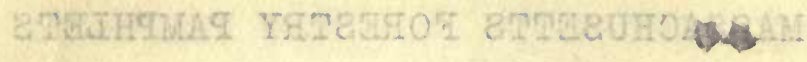

$$
I .0 V
$$

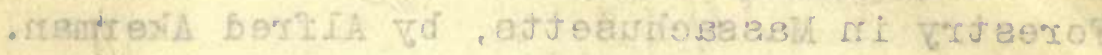

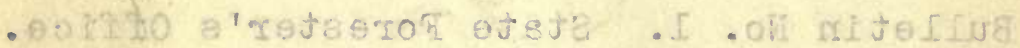

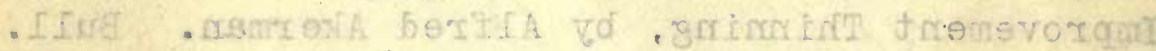
Main Lib.

- Forotry a'zejegrom ejate .S.OH

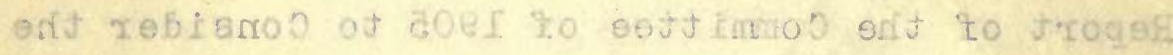

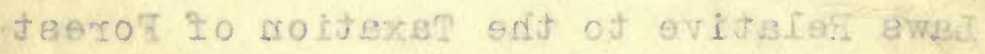
oli. IInga
$.9012 \div 0$
e'rejaerod ots a
$.2 b m a I$

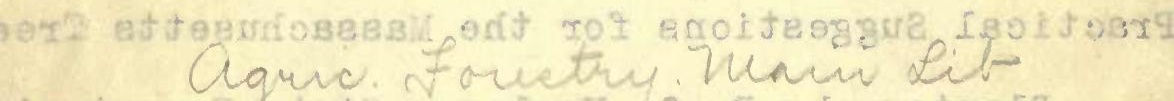

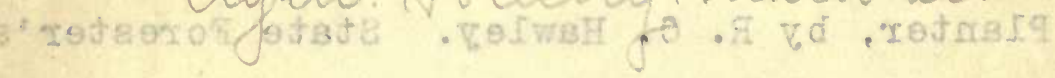

$$
\text { - .ota mijeflus .eoizzo }
$$

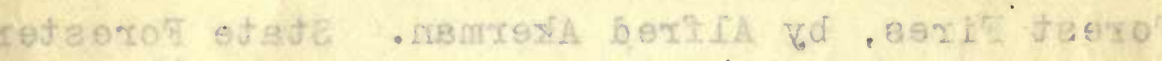

$$
\text { . . ovi inijofirre . avitio }
$$

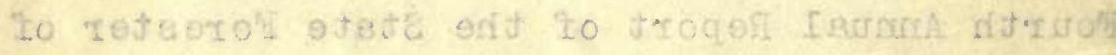
- roer . adjeastrionasin.

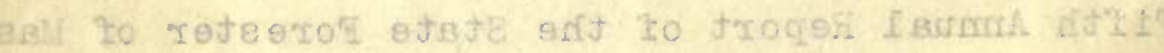

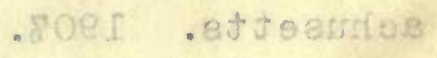

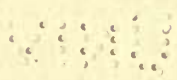
$\therefore y_{1}+\cdots$ 


\section{Yalter Mulfored}

\section{REPORT OF COMMITTEE ON EXPERIMENTS AND STA- TION WORK.}

[Read and accepted at the Annual Meeting, Jan. 8, 1902.]

A hasty examination of the Experiment Station shows that the professors have all that they can do in each department. Every year our Legislature is increasing the work of the station, and the time is near, if it has not already come, when the heads of the several departments will be compelled to confine their work to the Experiment Station. There are departments which would be very much improved if the whole time of the professors was given to the work of the station.

The Experiment Station will never be what it ought to be while its professors occupy two positions, - one as teachers in the college, and the other as heads of departments in the Experiment Station. The work is not alike. If a professor was called upon to speak to his class, he might be thinking of some new method of changing the earth so as to make the materials better adapted to plant growth, or the mixing of some chemicals which would kill an insect and save the tree, or perhaps he might be mixing some compound that would cheapen the production of milk.

The work which is now being given to some of the professors is of a character that interferes with their work at the station, and at the same time cannot be what it should be at the college. This is a fact that must be evident to every teacher who has had college work to do.

Respectfully submitted, 
302: $\because$ BOARD OF AGRICULTURE. [Pub. Doc.

\section{Report Mase. Board of Agriculture}

REP0RT OF COMMITTEE ON FORESTRY, ROADS AND ROADSIDE IMPROVEMENTS.

[Read and accepted at the Annual Meeting, Jan. 7, 1902.]

Your committee has had no special task placed upon it by yourselves nor by the Legislature; and, as your first vice-president is to address us during this meeting upon "Massachusetts forestry," and is well informed as to its condition throughout the State, it seems to be out of place for us to report at any length upon this subject.

As to roads, the matter of the State's interest has been placed in the charge of the Highway Commission, which has funds at its command for the purpose and has skilled employees under its direction, so that it is unnecessary for us to cope with a subject so much better placed.

Forestry and arboriculture are receiving attention from the several park boards of the State in varying degrees of success, but greater than formerly; and they seek information from other sources that exist, and which have special opportunities of acquiring knowledge upon those lines. Schools of forestry, well established, are actively at work in Yale University, Cornell, Biltmore, N. C., and elsewhere; and we have as noted an exhibit of growth and study of trees at the Arnold Arboretum as probably exists. The effect of the tree warden law has been promotive of good, and has greatly increased intelligent interest in trees.

As to roadside improvements, the general interest has increased of late years. Better roads and the extension of street car service have encouraged travel among our people, who are taking far greater interest in the condition of our roadsides, and who are cultivating a decidedly healthy opinion that reasonable protection of their natural beauty and prevention of injury from local ignorance should receive 
more careful public attention. This even has extended to opinions that individual owners have no right to allow injury to their own property to exist which brings injury to others. Hideous signs should be fought by crusades of instruction, and by advancing the idea of love of the beautiful and increased appreciation of the value of landscape purity.

I desire to refer to a great forestry work which is going on in this State, to the benefit of many people, indeed, for many generations into the future. While this great work is known in fact, it is too little realized in its vast details. It will become a great object lesson to all visitors. I can only lead up to and barely touch upon details at this time; nor is the forestry work there yet so formulated in report for me to have the knowledge that will enable me to do more than refer to what it must become; nor can it be said how far the public can be permitted to enter upon the great reservations of land, with their forest and other coverings, which are to protect the superb and extensive water basin that will exist at no very distant day in the Nashua River valley above Clinton.

The Nashua River water-shed is given as 118.23 square miles (75,667.20 acres). The area of the reservoir when full is 6.56 square miles (4,199 acres) ; its storage capacity is given as $63,068,000,000$ gallons; depth of water near the great dam above level of existing mill pond is 107 feet, with an average depth of 46 feet; its high-water mark is 385 feet above the level of high tide. The natural hills, dikes and the great dam keep the water enclosed. "The top of the dam is $\mathbf{1 0}$ feet above the level of the full reservoir. At the water level it has a thickness of 19 feet, and 145 feet below this level a thickness of $1191 / 2$ feet. The total distance across the valley on the line of the main portion of the dam, at high-water level, is 1,250 feet. The maximum depth of high water to the rock at the down-stream edge of the dam is 158 feet." The size of the dam is given, and its figures tell additionally of the extensiveness of the protection of, and receptacle for, this vast body of pure water for more than half the people of our State. 
This shows you that, with a great necessary change in grades and character over the reservoir tract and far beyond in the 118.23 square miles of water-shed, a large amount of deforesting, reforesting and road building will be eventually completed. So you readily imagine that great problems on these several lines that are laid down by law as a care of your committee have been exemplified under the direction of the Metropolitan Water Board, with the best advice that they have been able to receive, and to the State's great good for all time. It will form a State park under their care, - first, for preserving the purity of that water supply, and second, as a delight to many people. For reforesting, nurseries of young trees are being fostered, and mother earth has been improved, when necessary and practicable, to encourage the young growth to become future forests of most useful form and character, which shall hold the earth in place and improve the general usefulness of the watershed. The proper care of the older trees of natural growth becomes also a charge.

There appears to have been a comparatively small amount of damage by fire to woodlands during the past year, chiefly on account of the well-distributed rains during the time when dryness of underbrush and soil makes such injury possible. In forestry work the greatest discouragement and injury come from fires; and we should advise as great a division as possible of woodlands into separate tracts, by cart paths and roads and highways, in order to bring the possibility of preventing and ease of fighting such fires to the maximum.

Respectfully submitted,

FRANCIS H. APPLETON,

Chairman. 
This volume also contains reference lists of other laws, as follows : dairy, 1785-1901 ; horse, 1788-1901 ; dog, 17911901 ; forestry, 1853-1901 ; fertilizer, 1869-1901.

A companion volume has been prepared, in which to preserve copies of similar laws, beginning with the year 1902 .

Considerable material of historical interest, particularly that relating to the State Board of Agriculture, has been collected, and there is now in the custody of the librarian much data which may prove of value should a history of the Board or of other agricultural organizations be written. The librarian has in mind the preparation of what might be termed a history of organized agriculture in Massachusetts in the nineteenth century, for preservation in the office, or for publication, as the Board might determine. A brief history of the movement leading up to the formation of the State Board of Agriculture has already been compiled; also data covering the first ten years of the Board's existence.

Respectfully submitted,

F. H. FOWLER,

Librarian. 


\section{Report Maves. Boad of Agriculture}

\section{MASSACHUSETTS FORESTRY.}

BY HON. WM. R. SESSIONS OF SPRINGFIELD.

This subject was assigned to me, as I understand, not because I am an expert in forestry, or even a student of the subject, but because at the last annual meeting of the Board I advanced some suggestions for future action by the State that might lead to practical work in the line of forestry ; work that might help future generations out of the present unfavorable conditions that have been brought upon us by the management of the woodlands of the State by the owners of such property. It was doubtless expected that I would in this paper elaborate a plan for the suggested State action. I am not prepared to do so, but may be able to state facts and present further suggestions that may serve as hints to students of the Massachusetts forest problem, or at least more fully explain the position assumed at the last annual meeting.

I think it will be agreed that it is folly to expect owners to expend money in planting trees, or in fostering the growth of timber from the spontaneous growth of our woodlands and neglected hillsides. Our people are unwilling to invest money for the benefit of posterity, with no expectation of an annual income or for any return during their lifetime. There are several reasons why this condition prevails. If a man should decide to grow a timber forest, he could have little hope that his children would be owners of the property when it was ready to furnish a financial return for his investment in land and care of forest. The owners of our woodlands and abandoned pasture lands are very largely men of small means, who cannot afford any outlay that does not offer a reasonable prospect of a return in the shape of an income on the investment during their 
own lifetime. The majority of such owners are well advanced in years, and must, if possible, get something out of their property to support them in their declining years. All property is subject to taxation, that which affords no income as well as that which gives an annual return. As woodland increases in value by growth, the taxes are increased, until the owner with small means is practically compelled to cut the wood as soon as he can get anything for it. He can hardly wait for railroad ties, much less for valuable timber and other lumber. He cannot consider the public welfare, though he may be well aware that the covering of his land with mature forest growth is necessary for the conservation of the water supply for the centres of population and for the maintenance of a steady flow of the streams that furnish water power to numerous manufacturing establishments, so necessary to the prosperity of the State and which furnish employment to the working people. It is said to be folly to preach Christianity to a starving man. It is equally foolish to urge the benefit to the community from hillsides covered with a mature forest growth, when the owner must get something from those hillsides to pay the taxes on them and to help "keep the wolf from the door." As long as present conditions continue, just so long will the cutting of immature tree growth continue, and our hillsides will bear only a covering of sprouts and brush. The flow of our streams wiill continue to decrease except in time of freshets, and the problem of water supply for our cities will cause more and more anxiety to all those who feel a responsibility for the welfare of those who will come after us.

Doubtless something should be done. Preaching will not avail. The owners cannot do it, and, if they were financially able, would not feel under obligation, as a class, to make sacrifices for the good of the community and posterity. The community should pay its own bills. Our State has always recognized the fact that it was under obligations to provide for the necessities of the people and for the good of posterity in the matters of education, support of the poor and care of the insane; and in later years for water supply, 
sewerage and public parks, as well as for cheap transportation and convenient harbor accommodations. What is more logical than that the provision for future generations in conserving our water power and water supply should be undertaken by the State, in providing mature forest cover for the hills from which the streams receive their supply of water? In most European countries this burden was long ago assumed by the several governments, and was considered of so much vital importance that wars, conquests and revolutions have in nearly all countries left the policy in this regard unchanged. According to a paper read before the American Economic Association in 1890, 26 per cent, or $34,353,743$ acres, of the surface of the German empire is covered with forest; and the State either owns or controls about twothirds of this enormous area, or 22,902,495 acres. In France 17 per cent of the surface is wooded area, and nearly one-third of the same, or 7,373,068 acres, are either owned or controlled by the government.

In addition to the forest owned or controlled, most European governments maintain a rigid oversight of the forests owned by individuals. The owners can only cut their wood and timber under government regulations. These regulations generally require the present area of forest to be preserved intact, and compel owners to plant trees, if necessary, to replace such as they are allowed to cut. The government stands ready to purchase, at a fair price, any forest lands that the owners wish to sell, thus saving owners from severe loss from government regulations.

It is true that early conditions in Europe were much more favorable to government ownership and control than those of this State at the present time. Fernow says: "In Europe, thanks to a certain feudal system, large forest areas were preserved, more or less intact, in strong controlling hands, until the territory was gradually covered by a dense stable population, which necessitated conservative utilization of all resources and careful adjustment of private and communal interests."

The conditions in Massachusetts are radically different. All the forest lands are divided into comparatively small 
private holdings, and until these conditions are changed nothing of moment can be accomplished in conserving the forests for the public good, for in this country private owners will not submit to such strenuous rules as are in force in European countries. One condition is in a large degree favorable. The face of the country in this State is so broken and uneven that an abundant portion of the surface has been left without clearing, and thousands of acres that were cleared by our fathers are of so little value as cleared land that they may be cheaply bought and added to the forested area. According to our last census, about 35 per cent of the surface of the State is classed as woodland, and in addition there are many thousands of acres of poor bushy pasture that might well be bearing trees. If all this land was covered with mature forest growth instead of the brush and sprouts that now occupy so large a portion of it, the future of the water supply of the State would be assured so far as the presence of abundant forest areas could assure it.

It has been urged that the forest problem, so far as regards the propagation of commercial timber, should be left to private enterprise; with the suggestion that outside capital would eventually be invested in large areas, which, while acquired primarily for game preserves or private parks, would be likely to be managed by their owners in a way to promote the growth of commercial timber and incidentally help to conserve the water supply. From my point of view, while this outcome would be an improvement on the present condition of our forests, it is objectionable in that it would tend toward the establishment of a landed aristocracy, which is not in accord with the traditions of our Commonwealth. It is also directly contrary to the growing idea that the land is God's gift to the people. To my mind it would be far better if a large part of the great area of wooded land, waste land and semi-waste land in our State was owned by the State, and that whatever of financial return could be realized therefrom in the future should benefit the inhabitants as a whole.

At first thought this may seem impracticable if not im- 
possible, and it may seem that the State would be unable to bear the financial burden that the purchase of such an enormous area would impose. The last State census gives the value of all the woodland in the State at something less than $\$ 24,000,000$. This is a large sum, but when we remember the millions the State so freely spent in building the Hoosac Tunnel to better the transportation facilities of Boston and the eastern part of the State, and the other millions expended for additions to the State House and for the small open spaces about it, it may not seem such an enormous undertaking. We should also remember that the $\$ 24,000,000$ covers the valuation of about $1,500,000$ acres of land, and that it includes the 414 acres of woodland in Suffolk County, at a valuation of almost $\$ 1,000,000$, or about $\$ 2,200$ per acre; also that of Essex, Middlesex and Norfolk, where the valuation is very much higher than that of the rest of the State, for the obvious reason that most of the woodland in these counties lies in close proximity to cities and large towns. The census valuation of woodland in the other counties is much less per acre, and the field of State experiment in forest ownership would naturally be largely in these other counties. The valuation of all the woodland in nine of the counties, viz., Berkshire, Franklin, Hampshire, Hampden, Worcester, Bristol, Plymouth, Barnstable and Dukes, is about $\$ 15,840,000$. If we leave out of this total the value of the comparatively few acres that have been artificially planted to forest and are naturally valued highly by their owners, we shall have in these nine counties 279,030 acres of wood of over thirty years' growth, valued at $\$ 6,270,699$, or an average of $\$ 22.12$ per acre; and 800,012 acres of wood of a growth of thirty years and under, valued at $\$ 8,718,393$, or an average of $\$ 10.90$ per acre. In addition, there are large areas of land in these counties given in the census as unimproved, unimprovable and unclassified. These are mostly cheap lands, and would doubtless be generally suitable for forest growth. There are of these classes of land in those counties 302,562 acres, valued at $\$ 2,218,688$, or an average of $\$ 7.33$ per acre. In the nine counties under consideration there are $1,102,574$ 
acres of wood of thirty years growth or less, unimproved, unimprovable and unclassified lands, valued at $\$ 10,937,081$, or an average of about $\$ 10$ per acre.

By further examination of the census.we shall find that there are large areas of land valued at a much cheaper rate. If we consider the cheaper classes in only the four western counties, leaving out the wood of over thirty years' growth, we find in Berkshire County 188,207 acres, valued at $\$ 1,289,909$, or an average of $\$ 6.85$ per acre; in Franklin County 145,154 acres, valued at $\$ 873,645$, or an average of $\$ 6.02$ per acre; in Hampshire County 110,822 acres, valued at $\$ 879,689$, or an average of $\$ 7.94$ per acre; in Hampden County 122,980 acres, valued at $\$ 1,183,807$, or an average of $\$ 9.63$ per acre. Taking the four western counties together, there are 567,163 acres, valued at $\$ 4,227,050$, or an average of $\$ 7.47$ per acre. These figures, it must be remembered, include all the land of these four classes, the woodland from twenty-five to thirty years' growth, that situated near large towns, railroad stations and other favored localities.

If we still further examine the census for cheap lands we find in several towns in the four western counties what we seek. Adding to the four classes last considered the pasture lands, we find in Becket 19,277 acres, valued at $\$ 80,380$, or $\$ 4.12$ per acre; in Florida 12,475 acres, valued at $\$ 61,875$, or $\$ 4.96$ per acre; in New Ashford 4,618 acres, valued at $\$ 18,845$, or $\$ 4.08$ per acre ; in Otis 21,694 acres, valued at $\$ 95,302$, or $\$ 4.39$ per acre ; in Peru 14,342 acres, valued at $\$ 58,363$, or $\$ 4.07$ per acre ; in Savoy 18,509 acres, valued at $\$ 65,837$, or $\$ 3.53$ per acre; in Hawley 17,933 acres, valued at $\$ 59,950$, or $\$ 3.34$ per acre; in Rowe 10,580 acres, valued at $\$ 44,077$, or $\$ 4.16$ per acre ; in Monroe 4,781 acres, valued at $\$ 21,966$, or $\$ 4.59$ per acre; in Granville 19,684 acres, valued at $\$ 78,800$, or $\$ 4.00$ per acre ; in Tolland 13,736 acres, valued at $\$ 56,440$, or $\$ 4.11$ per acre; in Goshen 8,037 acres, valued at $\$ 44,217$, or $\$ 5.50$ per acre ; in Pelham 14,245 acres, valued at $\$ 79,321$, or $\$ 5.57$ per acre; in Plainfield 11,313 acres, valued at $\$ 47,400$, or $\$ 4.19$ per acre; or in these fourteen towns 
191,224 acres of land, valued at $\$ 812,773$, - an average of $\$ 4.25$ per acre.

These figures also include all the land in the several classes considered. It is well known to all who are at all familiar with the condition in the four western counties that there are thousands of acres recently cut over that can be bought for $\$ 3$ per acre, or even less.

The figures given above have been taken from the census, and, lest it may be thought that the values given are too low, I will refer to prices at which farms are offered by their owners in the "Catalogue of Farms in Massachusetts for sale at a low price," recently issued by the secretary of the Board of Agriculture. In that pamphlet are advertised 54 farms, containing 9,298 acres, for between $\$ 7$ and $\$ 8$ per acre; 5 farms, containing 875 acres, for between $\$ 6$ and $\$ 7$ per acre; 7 farms, containing 1,250 acres, for between $\$ 5$ and $\$ 6$ per acre; 6 farms, containing 1,940 acres, for between $\$ 4$ and $\$ 5$ per acre; 7 farms, containing 1,350 acres, for between $\$ 3$ and $\$ 4$ per acre; and 5 farms, containing 1,173 acres, for $\$ 3$ or less per acre. Most of these farms have buildings, fences, orchards and other improvements.

Since writing the above I have learned that a farm of 139 acres, formerly among the best in one of our most thriving hill towns, was during the past year sold for $\$ 100$. It was situated in a remote neighborhood; the buildings had disappeared, but all the cleared land was well fenced and used as a pasture, said to be a good pasture. The woodland was covered with a vigorous growth of various ages. The Oliver Smith Charities had held a mortgage of several hundred dollars on the property for several years, and had been obliged to foreclose. After long-continued effort to obtain a better price, the agent in charge accepted the offer of $\$ 100$ for the property, as the best he could get for it.

Several of the States of the Union have acquired lands for forestry experiment, and the matter is being generally urged by those interested in the perpetuation of the forests of the country. It was not the purpose of this paper to urge a definite plan, but to show the opportunity for and feasibility of State action. I have shown that there is an 
abundance of cheap land suitable for forest growth within the State. The State cannot do anything in the line of forestry without land to work upon. Provision might be made for a beginning by the purchase of lands offered for sale in lots of not less than a given number of acres, and at a price not exceeding a fixed limit. An official or board would be needed, whose duty would be to guard the interests of the State, making sure that no higher price was paid for lands than was necessary. This officer or board should have some latitude as to prices that might be paid, varying according to location and quality of land, condition of the forest growth, etc. The care of the land purchased would naturally devolve upon the same official or board, and methods for protection against fire and prevention of trespassing would be the first duty. The purchase of land would naturally begin with such as could be had at the lowest price, and only lands offered by the owners would be at first secured. Without doubt large areas would be offered at a low price. It would of course be necessary that some plan be adopted whereby the municipalities within which the lands purchased lay could be reimbursed for the loss of the annual taxes that had been realized from such land. It might be provided that the State should pay into the treasury of such municipality annually a sum equal to the amount of taxes levied on the land purchased in the year next preceding the purchase. If such a plan proved unsatisfactory, doubtless thoughtful men could work out a solution that would be just and reasonable. When plans for the improvement of the forests by scientific methods have been made, more latitude as to prices to be paid might be given, so that the tracts owned by the State might be increased to suitable size for most efficient improvement; but there is no question but land enough would be ready for a beginning in many localities.

What the financial result would be in after years can only be estimated. If the opinions of forestry experts are worthy of credence, and I believe they are, we must believe that with proper care and management these lands would furnish a large net revenue in years to come, proportionate to the 
number of acres acquired by the State. It is a well-known fact that European countries receive large additions to their revenue from government forests. Sir Herbert Maxwell states, in the "Nineteenth Century" for October, that the government forests of Belgium, covering 1,7.40,000 acres, yield a return of $\$ 20,000,000$ annually. 


\title{
Commonforealth of athasarbursetts
}

\author{
STATE FoRESTER'S OFFice
}

\section{FORESTRY IN MASSACHUSETTS}

BY

\begin{abstract}
ALFRED AKERMAN, M.F.
\end{abstract}
STATE FORESTER

THIRD EDITION, REVISED

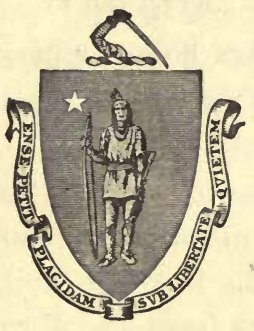

BOSTON

WRIGHT \& POTTER PRINTING CO., STATE PRINTERS

18 Post Office Square 


\section{MassachusetTs State Forest Service}

Alfred Arerman, M.F., State Forester

Ralph C. Hawley, M.F., Assistant State Forester Walter K. Fobes, Clerk

APPROVed BY

The State Board of Publication 


\section{FORESTRY IN MASSACHUSETTS}

\section{Part I}

\section{INTRODUCTION}

"Forestry is the science and art of forming and cultivating forests ; the management of growing timber." Forestry is distinguished from arboriculture by the fact that arboriculture deals with trees as individuals, while forestry deals with trees in forest stands. It is distinguished from landscape gardening by its different point of view. Landscape gardening often deals with trees singly and in groups, but always with the purpose of producing artistic effects; if any timber or wood is produced, it is merely incidental. Forestry, on the other hand, is chiefly concerned with the economic production of merchantable wood and timber.

The considerations, however, which make forests desirable are many; and they vary to some extent in the different sections of a country, and also to some extent in the same section, according to local needs and the desires of individual owners of woodland. The protection of the soil, the conservation of moisture, and the preservation of the natural beauty of a country-side are often important considerations, as well as the production of forest supplies.

As a rule, if forestry is practised for commercial purposes, if the land is made to produce continuously the greatest amount of merchantable material with the least possible expenditure, the protective and beautifying functions of the forest will also be performed. 


\section{Importance of Forestry in Massachusetts}

Improved management of woodlands in this Commonwealth is of great importance. The United States Geological Survey estimates that 2,688,000 acres, or 50 per cent., of the area of the Commonwealth is in woodlands, the total area being 5,321,600 acres. As there is a considerable area of waste land, old fields, abandoned pastures and the like, a part of which is capable of bearing forest growth, and which was not included in the above classification, the amount of land available for forest purposes must be in the neighborhood of 3,000,000 acres. At present much of this area is occupied with scattering and decrepit growth, and much of it has been burned over and otherwise abused until its productive eapacity has been greatly reduced. The United States census for 1900 gave $\$ 3,626,515$ as the annual output of woodlands in Massachusetts. This is not the net production: it is the value of logs, ties, posts, firewood, etc., delivered. The 3,000,000 acres available could with proper management produce, and produce continuously, several times the present output. By neglecting to practise forestry, the owners of woodlands are allowing a great resource of raw material to go to waste.

In the mean time, our manufacturers are going to Canada, to the south, the middle west, and even to the Pacific coast, to get their supplies. And they are sending money with their orders, that might go to owners in Massachusetts and be spent here.

Wood is always needed. In spite of the many substitutes that have been found for it, wood is more in demand to-day than ever before. The amount of wood annually consumed is constantly increasing, although the amount relative to other raw materials has decreased. And the prices paid for wood supplies are constantly increasing.

So, aside from other considerations, forestry, from an economic point of view, is of great importance to land owners, to manufacturers, and to the public. 


\section{The Fundamentals}

There are five fundamental conditions that must precede or accompany the permanent development of forestry in any country. The first is the presence of a considerable area of non-agricultural land which is capable of bearing forest growth; the second is a good market for forest products; the third is the presence of good transportation facilities; the fourth is an adequate system of protection from fires; and the fifth is a fair method of taxation for forest lands.

\section{(1) Non-agricultural Land}

In another connection it was stated that probably $3,000,000$ out of $5,321,600$ acres in the Commonwealth are available for forest purposes. They are by nature non-agricultural lands; they are not suitable for other than forest purposes, and therefore ought to be in permanent forest.

\section{(2) Good Markets}

The second condition, that of a good market for forest products, is also fulfilled in Massachusetts. All through the State there are numerous cities, towns and villages, and wherever these are found there is a demand for the products of the forest. Where building is going on, there is a call for lumber; where manufacturing is going on, wood is being used somewhere in the process of manufacture or in crating the product for shipment; where there are railroads, there is a demand for ties; where there are telephone and telegraph lines, there is a demand for poles; and where farming is going on, there is a demand for lumber for outbuildings, posts for fences and firewood for heating and cooking purposes. The intensiveness of forest cultivation depends largely on the market for forest products, and the market for forest products depends largely on the density and distribution of population. There is only one State in the Union that has a denser population than Massachusetts, and, although congested around Boston, there is no large section of the State that is not settled. The distribution of cities may be taken as an 
illustration of the point just made. In the extreme western part of the State are North Adams and Pittsfield; in the Connecticut valley, Northampton, Holyoke and Springfield; in the central part, Fitchburg and Worcester; and in the eastern part, Lowell, Lawrence, Haverhill, Greater Boston, Brockton, Taunton, New Bedford and Fall River. There is considerable manufacturing in all these places. Moreover, manufacturing is going on in almost every small town. And where there is manufacturing, there is always a demand for wood in various forms. When we add to these demands the - demands of the railroads, telephone and telegraph companies and of the farmer for his fences and buildings, it is readily seen that a market for wood and lumber is not far to seek in any considerable part of the State. No state in the Union has better markets.

\section{(3) Transportation Facilities}

The third condition, that of easy transportation from place to place, is also fulfilled in Massachusetts. If a glance be taken at the map of the State, it will be seen that its surface is traversed by a network of railroads and wagon roads. It is true that many of these wagon roads are not what they should be, and it is well that we have a Highway Commission to make them better; but when our roads are compared with those in most other States, Massachusetts does not suffer by the comparison.

Transportation has an important bearing on forestry. Forest products are as a rule bulky, and their transportation is consequently a considerable item in the cost of marketing; and whether this or that measure can be adopted in the woods often depends on the question whether this or that bulky article can be carried to market with a margin of profit, or not. If the transportation facilities are good, much more intensive forestry can be practised than otherwise.

\section{(4) Protection from Fire}

At present the Commonwealth does not have an adequate system of protection from forest fires. In saying this, it is not the intention of the writer to criticise adversely the fire- 
wards nor the district police to whom they report through the selectmen. The fault is in the system, rather than in its personnel.

Fire is the greatest enemy of the forest. It not only injures and destroys merchantable timber, but it often destroys for a number of years the conditions which are conducive to growth, so that the damage done is more than the injury to or the destruction of the merchantable part of a stand of trees.

We raise a hue and cry about the "devastation" wrought by the lumberman; we say that he is cutting all he can get out of his woods, without regard to future crops. But in many cases the lumberman has an excellent reason for cutting as severely as he does, and that reason is, that he would rather have his money in a bank than to have it in the woods exposed to fire. If we want the lumberman to act differently, we must meet him half-way; we must protect his crop to the extent of making it possible for him to insure it at reasonable rates, that do not exceed the rate of growth of the crop.

The present conditions must be improved if forestry in this State is to make rapid and substantial progress.

\section{(5) A Fair Method of Taxation}

There is a great deal of dissatisfaction with the present method of assessing taxes on forest lands. This dissatisfaction is shown by the laws that the different States are enacting along these lines. Pennsylvania has a rebate system; if a private owner will fulfill certain conditions, he receives a portion of his taxes back after they have been paid. Connecticut, Massachusetts and other States also have special laws in regard to the taxation of certain classes of woodlands. For the most part these laws are not operative, because they were not carefully thought out. They serve to show the feeling of discontent with the present system, but they do not furnish a satisfactory solution of the problem.

The system, now generally in vogue, of assessing forest lands for purposes of taxation, provides for the taxation not only of the land but of the growing crop as well. A farmer's wheat crop is not taxed while it is growing. An orchard or 
a vineyard yields returns in a very few years, but the wood lot is oftentimes taxed for years before any returns come in. Suppose, for example, a piece of land is planted to white pine, which is to be cut fifty years from now. As soon as that pine has reached a size at which it adds any value to the land, the property is assessed accordingly until it is cut, when it is again put back to the value of the land without the crop. In other words, the present system provides for the taxation of a raw material not only once but many times. When this raw material is so universally used in our manufactures, such heavy taxation is of doubtful expediency.

So there is dissatisfaction for two reasons : first, the crop as well as the land is taxed, which is not the case with ordinary agricultural crops; and, second, the crop is taxed while it is not bringing in anything, and therefore the owner is not in a condition to pay taxes on it.

Pursuant to a resolve of the General Court of 1905 a committee to investigate the problem of taxing forest lands. was appointed. The committee consisted of the Tax Commissioner, the chairman of the Harbor and Land Commission, the State Forester, three farmers, and a real-estate expert. The committee embodied its findings in a report which was printed as House Document No. 134. In order to make this report available for general distribution it has been reprinted as Bulletin No. 3 of this office, and may be had on application.

A partial consideration of the recommendations contained in this report was given this year, and it was referred to the General Court of 1907 for further consideration.

It is hoped that a satisfactory solution of this most perplexing problem will be found. Indeed, it must be found before private owners will be disposed to allow their timber crops to stand long enough to reach maturity.

\section{Recapitulation}

These five conditions, therefore, are fundamental to a permanent and successful development of forestry : (1) the presence of a considerable area of non-agricultural land that is capable of bearing forest growth; (2) a good market for 
forest products; (3) good transportation facilities ; (4) an adequate system for protection from forest fires; (5) a fair method of taxation of forest lands. Three of these conditions are fulfilled in the Commonwealth, but an improvement is not only desirable but necessary in fire protection and the method of taxation.

\section{Part II}

\section{The Commonwealth's Forest Policy}

The General Court of 1904 established the office of State Forester. A brief review of the work of the office will show how the State is going to work to make our forests more productive and to increase their area.

\section{Lectures at the Agricultural College}

The act establishing the office of State Forester mentions several lines of work, but leaves the execution of all except one to his discretion. The one exception is that he shall give a course of lectures on the art and science of forestry to the students at the Massachusetts Agricultural College at Amherst. The faculty of the college, acting under instructions from the trustees, have arranged the course as an elective for graduate students, seniors, and the short-course men who are there for the winter months only. Twenty-nine men elected the course in 1905, and fifty-four this year.

\section{Public Lectures}

Since taking up the work in August, 1904, the State Forester has given, in addition to the course at Amherst, fifty-six public lectures, talks, and addresses on various phases of forestry. These have been under the auspices of granges, farmers' clubs, improvement associations, and other interested organizations. Invitations to speak will hereafter be accepted only in the months of December, January, and March; the rest of the year will be reserved for work in the woods and other duties. These public lectures are undoubtedly conducive to the perpetuation, extension, and proper management of forests in the Commonwealth. Ap- 
plication for lectures is made on blanks which are furnished on request, and a copy of which is given below :-

\section{Town or City}

\section{DATE}

I hereby apply to the State Forester for a lecture on forestry, with special reference to

$\begin{array}{llc}\text { at } & \text {, on the } & 19 \\ \text { at } & \text { day of } & \\ \text {, the public to be invited ; and to }\end{array}$
cover the traveling expenses incident to accepting this application I agree to deposit dollars with the State Forester on or before

Signed

'The above application is accepted on the conditions named above.

\section{Signed}

State Forester

N.B. - Any unexpended balance, together with an itemized statement of expenses, will be promptly returned.

\section{The State Forest Nursery}

It is specified in the act creating the office that the State Forester may establish and maintain a nursery for the propagation of forest tree seedlings on such lands as the trustees of the Massachusetts Agricultural College may set aside for that purpose on the college grounds at Amherst. The stock raised in this nursery is to be furnished to private owners upon such terms as the forester may fix, subject to the approval of the Governor and Council.

It would be a mistake for the State to go into the wholesale raising of seedlings for public distribution if the nurserymen of this State will take up this line of business. Heretofore the nurserymen of this State, and in fact most of the nurserymen of the entire country, have been engaged in raising ornamental and shade trees at prices which prohibit their use in forest plantations; and it is likely that the nurserymen of this State will not care to take up a different line of work. 
In the mean time, a small nursery has been established, principally as a part of the course in practical forestry at the college. And if the nurserymen do not take up the production of stock for forest planting the nursery will be expanded as circumstances may warrant.

In any event, the output of the nursery will be disposed of only to bona-fide forest planters who are operating under planting plans that have been approved by the State Forester. It is not necessary that the State Forest Service prepare the plans, but it is necessary that a satisfactory plan be drawn up, and a copy of it be placed on file with the State Forester.

\section{Co-operation with the Owners of Woodlands}

Another line of work, which is mentioned in the act, is practical assistance to private owners in the management of their woodlands. This is perhaps the most important line of work that the State has taken up; and as much of the time of the State Forest Service as can be spared from other duties will be devoted to it; for it is believed that the forest problems of this State are to be solved largely by private owners. While the State has acquired some lands for park purposes, and a part of these lands can be used to grow timber, and while the State will probably follow the example of other States in the acquisition of lands to be managed as State forests, still, the greater part of the woodlands in the Commonwealth is and always will be in the hands of private owners. It is therefore very important that these private owners should be encouraged to practise improved forestry methods. The State has taken the position that it will furnish to the owners the services of experts, and leave the owners to make use of their services or not, as they see fit. This is the American way of doing things, - give the citizen the help he cannot readily supply himself, and then let him do as he likes about accepting the State's help. It stands out in marked contrast with the drastic forest measures adopted by foreign governments, which limit to an unwarrantable extent the rights of the private owner. 
Those who desire advice in the management of woodlands or in planting up waste lands are furnished with the following application blank:-

\section{Town or City}

\section{Date}

1. The State Forester, in order to collect information for a survey of the forest resources of the Commonwealth of Massachusetts, to spread a knowledge of practical forestry therein, and to improve the forest conditions thereof, agrees to examine and report on the lands of , in the county of , situated and described as follows:

2. The owner agrees to pay the travelling and subsistence expenses of the State Forester and his assistants while making such examination in a sum not to exceed dollars, and agrees to deposit that sum with the State Forester on or before

3. The owner agrees that the State Forester may publish, for the objects named in the first paragraph of this application, the information gained while making said examination.

4. This application may be cancelled by either party upon ten days' notice.

\section{Signed}

\section{Owner or Trustee}

\section{Boston, Mass.}

The above application is accepted and placed on file, to be taken up in its proper order.

\section{Signed}

State Forester

N.B. - Any unexpended balance, together with an itemized statement of expenses, will be promptly returned.

On January 1st, 46 applications for practical assistance had been received. The lands upon which advice has been given lie in all parts of the State, and amount to 6,545 acres. There are ten applications on file, which will be taken up as soon as other duties will permit.

It is doubtful whether the State can hold open such an offer for more than a few years. But for the present, when forestry is so little understood, and a continued supply of 
lumber means so much to the industries that use wood, and nearly all of them do use it in some form, - the State can well afford to make such an offer, on account of the educational value that such work has. A well-managed wood lot in a community is a force tending to encourage others in the same community to treat their wood lots in like manner.

\section{Co-operation between State and Federal Forest Service}

A plan of co-operation between the State Forester's office and the United States Bureau of Forestry was arranged in 1904, and submitted to the Governor and Council for temporary approval. Later the plan was submitted to the General Court, and, being accepted, has become a part of the State's forest policy. The plan calls for an interchange of useful information, and for co-operation in the collection and tabulation of forest data. It also provides against a duplication of work by the State or the United States.

\section{Publications}

This office has authority to publish useful information on forestry, and to distribute it to those interested. At this writing three leaflets and four bulletins have been published, making in all 17,600 pamphlets.

Nearly every wood lot has some features in common with many other wood lots, and when a working plan is made for one, some information is collected which many other owners can use; so, other publications will be issued from time to time as investigations progress.

\section{Part III}

\section{Some Important Woodland Problems}

The principal points in the State's forest policy have been touched on. There remain to be considered some matters that bear a close relation to the forest interests of the Commonwealth, although they are not directly connected with the State's forest policy. 


\section{State Forests}

The Commonwealth ought to extend its policy of park reservation to include genuine State forests. The reservations that have been made so far are distinctly for park purposes. There are, however, considerable areas in these reservations that could be used for timber growing. Portions of the Middlesex Fells and the Blue Hills reservations might be so utilized without any reduction in their value as parks; on the contrary, their park features would be enhanced. The same might be said of the Mount Wachusett, Mount Tom, and Greylock reservations, the Province Lands on the Cape, and the land surrounding the Clinton Reservoir. The land about this reservoir is already being planted by the Metropolitan Water and Sewerage Board. The creation and maintenance of a forest cover on this watershed may be regarded as a kind of insurance against pollution of the water. The forest in the Mount Wachusett reservation is also being improved by the commission which has that reservation in charge. It is to be hoped that all of the boards and commissions having State lands under their charge will follow these good examples, and make the lands that the State owns as productive of forest supplies as is consistent with the purpose for which they were acquired.

But the lands mentioned are small in area, and the State might well follow the precedent established by several other States, and acquire lands for the specific purpose of growing timber on them. New York has a forest reserve of 1,439,988 acres, and Pennsylvania has acquired 700,000 acres for forest purposes.

In addition to their use for timber production, State forests may be used as recreation grounds by the people. It is a race instinct with us to love the forest and to delight in it. It is not necessary to have rows of Lombardy poplars, banks of flowering shrubbery, tortuous gravel walks, ornate bridges over artificial ponds, and " keep-off-the-grass" signs, in order to have a serviceable park. While all these things are good enough in their way, there are some of us who occasionally long for nature in her wild simplicity and ruggedness. We 
long for a drive along a shady woodland road, or a tramp through the woods. It is sometimes a relief to escape from the "keep-off-the-grass" signs, to walk on the soft forest floor, to sit down on a stone that is not dressed and set in masonry. This relief is furnished by a timber-producing forest better than by any other form of park.

Lands for forest reservations can very often be acquired at a comparatively small cost. A few years ago Connecticut bought 900 acres, at an average cost of $\$ 1.64$ per acre. When once well stocked, the sale of mature timber should not only provide for the maintenance of such reservations, but should return a net revenue to the treasury of the State. The kingdom of Prussia owns 6,000,000 acres of forest land, from which the government derives a net annual revenue of $\$ 9,000,000$; and the republic of France owns 2,100,000 acres of forest land, from which it derives a net annual revenue of $\$ 1.91$ per acre.

\section{City and Town Forests}

There are many reasons why cities and towns would do well to own and manage woodlands, when suitable cheap lands are to be found within their boundaries. This could be done in many instances at a small initial cost; and, as said above in connection with State forests, such holdings should in time provide for their own maintenance, and even return a net annual revenue to the eity or town that owns them. There is a provision for the purchase and maintenance of such city and town forests already on the statute books (chapter 28, section 23, Revised Statutes), but so far no city or town has availed itself of its privileges under the law. The law is so framed, however, as to be a positive deterrent rather than an incentive to the acquisition of woodlands by cities and towns.

\section{The Relation of State, City, and Town Forests to Taxes}

We hear a great deal about the tax problem nowadays. The tax rate seems to be going up constantly, and yet we know that changing conditions, within the State, the cities and the towns, make it probable that the expenses of govern- 
ment will never be less than they are to-day. We complain more and more of the burden of taxes, and yet we demand that the government do more and more for us. We demand insurance commissioners to prevent the robbery of the public by unsound companies; we demand railroad commissions to keep the transportation companies from making an illegitimate use of their power; we demand schools and colleges and libraries, to prepare the coming generations for the duties of citizenship. We demand more of government than our fathers did, because the conditions of society are different from what they were in our fathers' day, and consequently government costs more now than it did then.

A number of ways have been suggested for keeping down the tax rate in the future. Among them has been suggested the purchase of cheap woodlands and waste lands, and the production of timber on them. This has been suggested as a form of business in which the State, a city or a town can engage for the purpose of raising revenue, without objectionable competition with the business of the tax payer. It is asserted by the advocates of this policy that there would be absolutely no objection from any quarter on the ground of competition.

There is food for serious thought in the suggestion. Foreign States and communities have tried this policy with success; and, although our conditions are not in some respects as favorable as theirs, still, they are such as to insure a profit on the investment.

\section{The Gypsy and Brown-tail Moths}

The presence of the gypsy and brown-tail moths in our woodlands in large and increasing numbers constitutes a serious forest problem. They are working out farther and farther from the residential sections, and this means that they are becoming more and more of a menace to our forest interests. The General Court of 1905 passed a bill which provides for systematic work against these moths. Those who are interested in the welfare of our forests should cooperate with the Superintendent in his efforts to suppress the moths. 


\section{Increasing Interest in Forestry}

The friends of the forest have been greatly encouraged by the interest which has been manifested recently in many parts of the Commonwealth. This interest is so hearty that it tempts some of us to look forward to a time when the old abandoned farm, coming up to red cedar and worthless birches, will be a thing of the past; when waste lands from the Cape to the Berkshires will be occupied with thrifty stands of white pine, chestnut and other useful timber trees; when the farmer's wood lot will produce saw logs, in addition to the usual supply of cord wood; when the State, the cities and the towns will own forests for the production of timber and for recreation grounds for the people; to a time when the greater part of the timber and wood supplies used in the Commonwealth will be produced within its borders. All of these things are possible and practicable from an economic point of view; but it will take time and hard work on the part of the friends of forestry, and an intelligent interest on the part of private owners and the general public.

Boston, April 23, 1906. 





\title{
Commontovalth of attlassarthusetts.
}

\author{
STATE FORESTER'S OFFICE.
}

\section{IMPROVEMENT THINNING,}

BY

\author{
ALFRED AKERMAN, M.F., \\ STATE FORESTER.
}

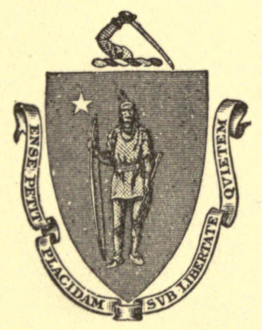

BOSTON :

WRIGHT \& POTTER PRINTING CO., STATE PRINTERS, 18 Post OfHice Square. 


\section{APPROVED BY}

The State Board of Publication. 


\title{
Massachusetts State Forest Service.
}

\author{
Alfred Akerman, M.F., State Forester. \\ Ralph C. Hawlex, M.F., Assistant State Forester. \\ Leverett Bradley, Agent. \\ Clarence W. Fearing, M.A., Special Agent. \\ Walter K. Fobes, Clerk.
}





\section{IMPROVEMENT THINNING.}

\section{INTRODUCTION.}

By improvement thinning is meant the systematic removal of a portion of the trees in a growing crop of timber to benefit the portion that remains. Improvement thinning is the principal means which the forester has at his disposal of influencing the development of a stand of forest trees. The farmer and the gardener have their distinctive methods of cultivation, by which they increase the yield and improve the quality of their crops. The forester cannot use the methods of the farmer and the gardener in growing crops of timber trees. The great expense of such methods, the different nature of the crop, and the rough and stony character of many forest soils, make a different and less expensive form of cultural treatment necessary, - that is, improvement thinning.

Improvement thinning is a very important part of forestry for us to consider here in Massachusetts for the coming quarter of a century. A great many people think that treeplanting is all there is to forestry. It is true that treeplanting is an important part of forest work. There are considerable areas of practically waste land in the Commonwealth that ought to be planted to forest trees, and it is economically sinful to allow them to lie idle when they might be producing something of value. But, while this is true, it is also true that the improvement of forests that already exist is just as important as the creation of new ones by planting. According to the estimate made by the United States Geological Survey, fifty-two per cent of the area of the Commonwealth is already covered with a growth of forest trees. It would seem that, if more emphasis ought to be placed on one branch of work than on another, it should be placed on increasing the productivity of our large forest area, rather than upon an extension of that area. 


\section{Is Thinning Practicable?}

There are many owners of woodlands who doubt the practicability of improvement thinning. They say that, while benefits may result to the stand, the cost of the work is prohibitive. Of course improvement thinnings are out of the question back in the Maine or Michigan woods, but with the market conditions which exist in most parts of Massachusetts they are practicable. The writer knows of cases where they have been executed at from 10 cents to $\$ 2$ net gain per cord, where the market was from eight to two and one-half miles from the woods. At one place it was asserted positively by the owner that the work would not pay; but when it was done it was found that the cost was $\$ 1.25$ per cord, and that the product sold on the ground for $\$ 1.50$ and $\$ 1.75$ per cord.

Another objection sometimes urged is, that the trees to be removed will lodge on other trees, so that they cannot be gotten down; or that they will break and injure other trees, in falling, to such an extent as to offset the improvement gained. The writer has in mind a stand of pine and a stand of spruce in New Hampshire, where this argument was used against the proposed thinning. The argument was answered by putting a few men at the work, and thinning sample areas. When it was done it was found that the remaining trees had not been broken to any extent in either stand, - not even in the pine, which was more liable to breakage; and that no trees had remained lodged in either stand, - not even in the spruce, which was a very close stand of slender poles, that were especially liable to lodge against the remaining trees.

When the thing has been done, and at a net gain, the time has passed for contending that it is impracticable.

\section{The Theory of Thinning.}

The principle which underlies the practice of thinning is to be found in the struggle for existence and the survival of the fittest. If we plant an acre in pine trees, for example, at a distance of six feet apart each way, or if an acre is 
seeded naturally with pine trees at approximately the same distance, there will be 1,200 trees on the acre at the time of starting. Each tree will have 36 square feet of space in which to spread its branches. Trees, being like some men, take all that their neighbors will allow; so each of these trees, provided that no accident happens to it, will grow and spread out its branches until they touch those of the surrounding trees. Then we have what is known in forestry as a "closed stand," - that is, a stand that completely shades the ground. As soon as the stand is closed the trees begin to crowd one another. The fight for existence is now on, and those trees which, by some little accidental advantage, manage to get ahead, are the ones that will survive. $\mathrm{By}$ the time the stand is fifty years old there will be approximately 400 trees standing on the acre where there were 1,200 at the start. The rest have perished in the fight, and some of those that are still living are destined to succumb within a few years.

By interfering in this struggle at the proper time and in the proper way, it is possible to avert the injury which may come from too fierce a conflict, and at the same time to play the trees off against one another, so that the struggle becomes a stimulating source of benefit to the individual trees and to the stand as a whole. The proper way to interfere is to execute moderate improvement thinnings from time to time, while the trees are growing.

The extent to which a stand of trees will respond to such treatment is remarkable. The writer wishes that those to whom these words are addressed could see the celebrated city forest (Sihlwald) of Zurich, Switzerland. Some of the stands in that forest have been thinned about once in seven years since the early stages of their development. Their long, straight, symmetrical trunks embody the energy that might have been wasted in useless competition with their neighbors. Their growth has been rapid. There are no undesirable species in the stand. The ground is fully utilized. 


\section{Practice of Thinning.}

When and How Often to Thin.

Of course the conditions which exist in most parts of this country do not permit of thinning as often as in some parts of Europe. Our market conditions are different, and we must be satisfied with a less intensive cultivation of our forests. A safe rule to follow is to thin a young stand as soon as the material to be removed has reached such a size that its sale will pay for its removal, and as often thereafter as the material to be removed has accumulated in sufficient quantities to pay for its removal. If this rule is followed, the improvement is a net gain. If the rate of growth of our native trees and their response to treatment were better known, and if our forests were better protected from fire, perhaps we could afford to thin a little before the material to be removed would pay for its removal. We could thin at a slight expense, and know whether the investment would be profitable. But in the existing circumstances it is far better to keep within the safety limit embodied in the rule just given.

In practice this would mean a moderate thinning when a stand is about thirty years of age, with a repetition every ten or fifteen years thereafter. The trees in some stands have not reached such a size in thirty years as to insure that those to be removed will pay for the work; while under more favorable circumstances thinnings may be undertaken at an earlier age than that mentioned.

\section{To What Extent to Thin.}

The extent to which a closed stand may be opened depends on several circumstances. The kind or kinds of trees that compose the stand, the nature of the soil, the character of the undergrowth, and the purpose for which the timber is to be grown, - all play a part in determining the degree of thinning. This is one of many matters in forestry that cannot be reduced to a rule.

The classes into which the trees in a closed stand gradu- 
ally become separated, in the course of their struggle for existence, are of assistance in determining the extent of a thinning. Four classes are usually distinguished. They are as follows: (1) dominant, (2) intermediate, (3) suppressed, (4) dead. Dominant trees are those that have their crowns in the light; they have kept ahead of the other trees in height growth. Intermediate trees are those that still have their crowns in the light, but are somewhat backward, and are destined to become suppressed trees in the near future. Suppressed trees are those that stand slightly below the intermediate class, and will probably die within a few years.

Moderate thinning would involve the removal of such of the intermediate trees as are interfering with the best development of the dominant trees. Of course the circumstances are often such that an occasional dominant tree must be removed; but care should be exercised in the removal of both dominant and intermediate trees, not to open up the stand to such an extent that undesirable undergrowth will be encouraged. In the case of shallow-rooted species, like the spruce, the stand should not be opened up too much, or it will become liable to windthrow. On the other hand, the stand must be opened enough to stimulate the growth of the remaining trees, or very little good will have been accomplished by the operation. The forester must balance one alternative against another, quickly and accurately, and decide in the case of each tree. In no case should the cover be broken into to such an extent that it will not close again in two or three years.

Whether suppressed and dead trees should be removed, depends principally upon whether they contain enough wood to make their removal along with the rest worth while. Some stimulation will result from the removal of certain of the suppressed trees, but most of them are so far behind the dominant trees that are to compose the final stand that their presence or absence has little effect, one way or the other, upon the development of the dominant trees. Yet it often pays to remove some of the suppressed, and sometimes even a portion of the dead trees, while the more important thin- 
ning is in progress ; although it would not, except in extraordinary cases, pay to go into a stand for suppressed and dead trees alone. And, on the general principle of clearing a stand of all useless material which might add to the dissemination of disease or increase the danger from fire, it is sometimes expedient to remove dead and suppressed trees, when it can be done without extra cost, while thinning is being done. On the other hand, it is sometimes desirable to retain the suppressed trees, or a portion of them, in order to keep the ground as well shaded as possible.

Another method of determining in a rough way the extent to which a thinning is to be carried, is to estimate the amount of wood standing on the area to be thinned, and to remove approximately a certain percentage of the volume of the stand. For instance, a given stand would run 25 cords per acre; approximately, 3.75 cords per acre, or 15 per cent of the volume of the stand, would be removed in a moderate thinning.

\section{Order of Preference.}

Certain species in a mixed stand are more desirable than others. The relative desirability of species is dependent in part on their market value, in part on the particular object that the owner may have in view, and in part on habits of growth and adaptability to the soil in which they may be. The forester, therefore, finds it useful to list the species in their proper order, bearing in mind the points mentioned above. For want of a better name, this list may be called the order of preference.

For hard-wood stands in Massachusetts the order of preference would usually be as follows: chestnut, white ash, hickory, white and red oak, sugar maple, yellow birch and paper birch, whitewood, beech, elm, etc. In the case of pine lands that are covered by a mixed growth, white pine would head the list.

To illustrate the use of such a list, let us suppose that a white ash and a yellow birch tree are standing side by side, and that the conditions are such that one should be removed. All other things being equal, the choice rests solely on the difference in species, and the birch would be removed and 
the ash left to grow. The reason for giving white ash the preference is that white ash stumpage sells for over twice as much as yellow birch stumpage.

\section{Modifications in Practice.}

After the order of preference has been determined, bearing in mind the market value of the several species in mixture, their habits of growth and adaptability to the soil, and the object that the owner may have in view, - it must be modified in many cases on account of defects in individual trees. Using the same example cited a moment ago, but supposing the yellow birch to be perfectly sound and the white ash to have a serious defect, - such as a large fire scar at its base, - then the yellow birch would be given preference over the ash.

A watchful eye should be kept for defects of other kinds, as well as that just mentioned. The shape of the trunk, the shape of the crown, the presence of indications of decay inside the trunk, and the general thriftiness of the tree, should all be taken into consideration.

The shape of the crown and its position in relation to surrounding crowns are of especial importance, and should be studied closely. The processes of respiration and assimilation are carried on in the foliage which composes the tree's crown. The crown of a tree is its lungs and stomach, so the development and health of the crown are closely related to the growth and health of the tree; and when a decision is to be made, the position, shape and health of the crown should be given great weight.

\section{How the Work is Done.}

When a given stand is to be thinned, the forester first ascertains the owner's needs and desires. If a forest working plan for the property has been prepared, he consults this, to acquaint himself with the general policy to be followed in dealing with the case under consideration. He next makes a rapid reconnoissance of the stand. He is then ready to mark the trees which are to be removed. 
The mark usually consists of a small blaze with a hatchet or axe on two sides of the trees to be removed, so that they can be easily distinguished as the workman moves back and forth through the stand. If the chopping is to be done by contract, it is well to have a marking hatchet with a raised letter or symbol on the back, and to hammer this into a third small blaze near the ground. This affords a check on choppers when they are inclined to cut more trees than is desirable, in order to increase their wood piles with as little work as possible.

When considerable areas are to be gone over, it pays to hire two men to do the marking, while the forester designates the trees. The men each take a strip of convenient width, and mark the trees in their respective strips as they advance. The forester moves along several paces in advance of and between the men.

\section{Importance of Careful Selection.}

To bear all of these points in mind, and also the degree to which the cover may be opened without danger, requires considerable skill. A great deal of harm is sometimes done to a forest stand by so-called "thinning out." In cases where a trained forester is called in to draw up a forest working plan, his recommendations as to improvement thinnings are often left to an inexperienced hand to carry out. The writer knows of a case where the men who had the contract to cut the wood were allowed to select the trees to be removed. It is high time that such important details should receive the personal attention of trained men.

\section{Improvement Thinnings combined with Other Operations.}

While an improvement thinning applies more particularly to the treatment of a dense stand in the process of development, it may also be combined with other work. When, for instance, a stand is very uneven in age, improvement thinning among the younger trees may go hand in hand with the removal of the mature trees in the stand, and the cost of each operation may be reduced by both being done at one time. However, it is well to keep the two opera- 
tions separated in theory, though they may be combined in practice. Another case, and a common one, is the preparation of a partially grown-up abandoned field for planting. In such places there are often small groups of excellent natural growth that can be thinned to advantage, while the ground is being cleared of scattering, limby trees as a preparation for planting.

\section{Results of the Thinning.}

\section{More Trees and Better Lumber.}

As improvement thinnings tend to the better spacing of the trees on a given area, their tendency is to a more complete utilization of the soil. If, when twenty trees are struggling with each other for survival, and so fiercely that all but five would be more or less injured, the forester can step in and make ten healthy, vigorous trees grow, then the soil over a given area will be made to produce much more per unit of area than when thinnings are not practised.

It is a self-evident truth that a stand in which the better timber trees are given the advantage will produce a higher percentage of good lumber than a stand in which the better trees are not given the advantage.

\section{Shorter Rotation.}

One of the principal advantages that are derived from improvement thinnings is that the rapidity of growth is increased, and hence the time that it takes to grow a crop of trees of a certain size is shortened.

Improvement thinnings are of comparatively recent introduction in this country, and it is not definitely known how much the rotation of crops can be shortened; but, judging from many years' trial in the forests of Europe and from a brief experience in America, it is safe to say that the rotation can be materially shortened.

This means a great saving in the long run. Suppose, for illustration, that it takes fifty years to grow a crop of pine boxboards on a given piece of land without the stand being thinned. Now, such a crop should be produced in forty- 
five years if the stand were thinned once or twice during its course of development. This would mean a saving of ten years in a hundred, or ten per cent of the time involved in growing such crops.

The saving of five years in fifty does not appeal to a mortal man with the same force that the actual saving to the industries of a country would warrant. The ordinary land owner is not so much interested in hastening the maturity of a crop which he cannot hope to reap, even if it can be done without expense, as he would be, could he hope to live to enjoy the gain. The long periods of time involved in producing timber crops make a powerful argument for State, city, and town ownership of considerable tracts of forest land, to be used and managed so as to insure timber supplies to future generations.

\section{Improved Appearance.}

In the course of improvement thinnings many unsightly trees are removed; many diseased and unthrifty trees are also removed. This, together with increase in general health and thrift, tends to make a forest stand more attractive to the eye. Where woodlands are used for park purposes as well as for timber production, moderate improvement thinnings are highly recommended. They should, however, be conducted under careful supervision, as the tendency is often towards a radical treatment.

Private owners, who wish to improve the appearance of their farms and estates, can in many instances do a great deal in that direction by the very simple means of improvement thinnings. 



\title{
Commonwealth of attrasarthrastts
}

\author{
STATE FORESTER'S OFFICE
}

REPORT OF THE COMMITTEE

of 1905 то

\section{CONSIDER THE LAWS RELATIVE TO THE}

\section{TAXation OF FoREST LANDS}

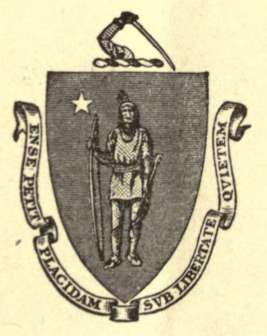

BOSTON

WRIGHT \& POTTER PRINTING CO., STATE PRINTERS 
APPROVED BY

The State Board of Publication 


\title{
MassachusetTs State Forest SERvice
}

\author{
Alfred Akerman, M.F., State Forester \\ Ralph C. Hawlex, M.F., Assistant State Forester \\ Leverett Bradley, Agent \\ Walter K. Fobes, Clerk
}





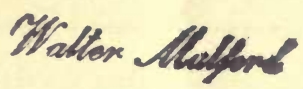

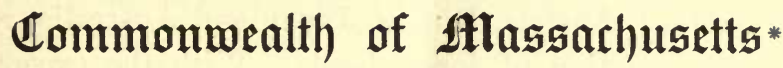

\section{REPORT}

OF THE

\section{COMMITTEE TO CONSIDER THE LAWS RELATIVE TO THE TAXATION OF FOREST LANDS}

\section{To the General Court.}

This committee was provided for in a resolve of the General Court, approved April 28, 1905:-

Resolved, That the tax commissioner and one of the harbor and land commissioners and the state forester, together with such other persons as the governor with the advice and consent of the council, may appoint, shall constitute a committee, serving without compensation, to examine and consider the laws of the Commonwealth and of other states and countries, relative to the taxation of forest lands. The committee shall report to the general court on or before the second Wednesday of January in the year nineteen hundred and six the result of their investigation, with any suggestions as to legislation which they may consider desirable for promoting the cultivation and improvement of forest lands within the Commonwealth. There shall be allowed to the committee for their expenses such sums as may be approved by the governor, not exceeding in the aggregate the sum of five hundred dollars.

We have examined the laws of other countries, other States, and of this State, and beg to submit our report thereon, together with certain recommendations for amendment to the laws of this Commonwealth.

* This report was originally printed as House Document No. 134. Inquiries about it and requests for copies have been so numerons that it is deemed advisable to publish it as a bulletin of the State Forester's office. Several notes and explanations have been added. These additions to the original text are clearly indicated. 


\section{Part I - Laws of Foreign Countries}

We have examined the laws of England, Germany, the Swiss Cantons, Austria, Russia, Japan and Australia, relative to the taxation of forest lands. With the exception of Australia, the methods of assessment are in advance of our own, because they recognize the fundamental principle that taxes should not lead to devastation or slovenly forestry.

An outline of some of these laws is given below, in order to illustrate the different methods that have been employed. In attempting to apply these methods to our conditions it must be borne in mind that the foreign laws are a part of a general system of taxation which in most cases differs from our own. In the recommendations which appear in the third part of this report we have selected and elaborated a method which, while embodying the essential principle of the foreign laws, is in harmony with our general system of taxation.

\section{Germany}

The forests are not taxed uniformly throughout the States of the German Empire.

There are three main taxes in vogue: (1) ground tax; (2) income tax; and (3) property tax.

One or two of these taxes are invariably levied upon the forests.

Ground tax is a tax upon the average productive capacity of a given soil, or the average yield. The soils, for that purpose, are estimated from time to time, and their average yield fixed for a time by the authority of the government.

Income tax is a tax upon the income irrespective of the source from which it is being derived.

Property tax (in German sense) is a tax upon any property in possession of an individual, corporation, etc., except land. 
I. Ground tax alone exists only in Bavaria, Wurttemberg, Alsace-Loraine, Mecklenburg.

II. Income and property taxes exist in Prussia.

III. Income and ground taxes exist in Saxony, Baden, Hessen, Saxe-Weimar, Oldenburg, Braunschweig, SaxeMeiningen, Saxe-Altenberg, Saxe-Coburg-Gotha, Anhalt, Schwarzburg - Sondershausen, Schwarzburg - Rudolstadt, Waldeck, Reuss, Lippe.

I. In Bavaria the tax is levied upon the gross yield of the forest, determined on the basis of land estimates made between 1808 and 1853. These estimates are antiquated.

In Wurttemberg the net yield of the forest is taxed. The land estimates were completed in 1887 .

In Alsace-Loraine the net yield of the forest is taxed.

II. In Prussia the ground tax introduced in 1861 (May 21) has been abolished by the law of July 14, 1893, as far as taxes from forest land payable into the State treasury are concerned. Ground tax, however, still remains optional with the counties, which are authorized by the law of 1893 to levy the taxes as they think best, either in the form of a ground tax upon the average net yield of the forest, or in the form of an income tax on the net revenue of the individuals.

The forests of Prussia are taxed for State needs according to the general income tax law of June 24, 1891. Besides the income tax there is still another so-called auxiliary or government property tax for forests of certain value, levied upon the forests of living persons (communities and corporations thus being excluded), according to their market value.

III. In Saxony there is (1) a ground tax levied upon the forest soil, according to its average net yield, estimated and fixed once for all by government authority at the time of a special investigation made about fifty years ago; and (2) an income tax upon the net revenue obtainable from private forests, such revenue being estimated periodically. 
The forests of Baden, Hessen, Braunschweig, SaxeWeimar, Oldenburg, Schwarzburg-Sondershausen, Anhalt, etc., are taxed in a similar way.

In case of accidents, like fire, insect depredation, etc., reductions are made from the estimated yield. Thus, in Prussia the reduction may vary from 20 to 50 per cent., according to the species and kind of forest (seedling or sprout growth). In Saxony a reduction of 16 per cent. is allowed in a coniferous forest; 12 per cent. in a deciduous, seedling forest; 8 per cent. in a coppice forest. In Wurttemberg, 25 per cent. in a coniferous forest; 20 per cent. in seedling, broadleaf forest; and nothing in coppice forest.

In Bavaria, Baden and Hessen such reductions are not provided by law.

In Baden newly established plantations are exempt from taxation for twenty years (law of 1886).

In Prussia, Bavaria, Wurttemberg, Hessen, etc., no such exemption from or reduction of taxes on new plantations exists.

\section{Austria}

In Austria the forests are subjected to a ground tax (law of May 24, 1869, and June 7, 1881), the land being estimated periodically, every fifteen years, - last time in 1895 ; and, since Oct. 25, 1896, also an income tax.

An exemption of new plantations is allowed for twentyfive years (law of 1869).

\section{- Russia}

In Russia the forests are taxed for State and county needs. The State forests are exempt from State taxation, but must pay the same county taxes that private forests do.

The main principle of taxation is to tax the forest land according to its value, or the revenue derived from it; in other words, the tax is supposed to be a ground tax.

The form in which this ground tax is levied varies con- 
siderably throughout the country, but the three most common forms are as follows:-

I. The tax is levied upon the forest according to the average annual revenue expected from it:-

a. Gross revenue.

b. Net revenue.

The procedure for determining the average revenue is to divide the forests into quality classes; forests that will yield timber for construction or cordwood or both; coniferous or deciduous forests; etc. The market price of the forest product obtainable from one acre is then divided by the number of years that it takes the trees to attain merchantable sizes, the result being the average annual gross revenue that can be expected from the forest. The average net revenue is found by deducting the average annual expenditure per acre from the gross average revenue.

The value of the forest land is found by capitalizing the net or gross revenue at a given rate of interest.

Thus, if the forest products from a forty-five year old stand on one acre are worth say $\$ 100$, the average gross revenue is equal to $\frac{100}{45}=\$ 2.22$. Assuming that the average annual expenses in protection and administration of the forest are 20 cents per acre per year, the net revenue per year is $\$ 2.02$. The value of the land then will be, at a rate of interest of 5 per cent., either $\frac{2.22}{0.05}=\$ 44.40$, when the gross revenue is capitalized, or $\frac{2.02}{0.05}=\$ 40.40$, when the net revenue is capitalized.

II. The tax is levied upon the forest on the basis of its actual annual revenue.

The actual revenue is determined in many ways. Often the actual annual revenue obtained in the State forests within the given locality is taken as a standard and applied to the other forests in that locality, or it is determined by the amount of timber cut down every year. In some cases the forest land is taxed only at the time when the timber is cut, remaining entirely untaxed while the timber is maturing. The tax is levied, after making an 
allowance of 10 per cent. for the cost of management, upon the actual revenue, its rates being dependent upon the age at which the forest is cut. Thus, if the forest is ten to fifteen years old, the tax amounts to 6 per cent. of the actual revenue; at fifteen years it is $51 / 2$ per cent.; twenty to twenty-five years, 5 per cent.; twenty-five to thirty years, $41 / 2$ per cent.; thirty to sixty years, 4 per cent.; sixty to ninety years, $31 / 2$ per cent.; ninety to one hundred and twenty years, 3 per cent.; one hundred and twenty years and above, $21 / 2$ per cent.

\section{Switzerland}

Canton Aargau. - The forests are assessed with reference to stand of wood, productiveness of soil, situation with regard to market, and local price of wood. Revisions in assessments are made every six years.

Canton Appenzell. - In part of territory forest lands are valued at one-half the selling price; in another part, two-thirds of the official valuation are subject to taxation.

Baselland. - Forest lands are taxed with the productive value in view. The productive value is determined by the government forest expert.

Baselstadt. - Arbitrary valuation without regard to yield, or even sale value. In some cases the land is uniformly taxed 4 francs per unit of area, without regard to locality or stand.

Borne. - Forests are valued according to their average power of production, based on a rational management.

Freiburg. - Forests of communes and of private persons are appraised at so much per square meter, and classed in their divisions by a commission. System rather arbitrary.

Cantonal forests are assessed according to average yield of last ten years.

Grisons. - Assessment based on yield that may be obtained without reduction of stand.

Lucerne. - Purchase value, location, yield and current prices of wood products are taken into consideration in assessing forest land. 
Neuchatel. - Valuation takes into account soil, stand and productiveness under rational management.

Nidwalden. - Assessment according to selling value.

St. Gall. - Forests are taxed at one-half selling value. If worked under a plan approved by the State, the assessment is according to their average yield.

Schaffhausen. - Private forests are assessed according to yield, which is determined by comparison with yield of State forests under working plans. The probable net annual yield is capitalized.

Soleure. - Private woodlands valued by capitalizing net annual yield at 5 per cent., and to this is added 4 per cent. of value of soil.

Thurgau. - Woodlands which are under working plans, providing for continuous production, are assessed by capitalizing the net annual yield.

Uri. - Valuation based on mean between selling value and productive power.

Valais. - There is a nominal tax on the soil, to which is added a tax on yield.

Vaud. - Forest land is taxed and any forest products which may be sold; but the standing timber and such products as are consumed on the place are exempt.

Zurich. - The net income forms the basis of taxation of forest lands.

\section{Part II - Laws of Other States}

As instructed in the resolve, we have carefully examined the laws of other States. We find that Colorado, Connecticut, Illinois, Indiana, Kansas, Maine, Massachusetts, Minnesota, Nebraska, New Hampshire, Pennsylvania, Rhode Island, Vermont and Wyoming have made special laws in regard to the taxation of forest lands, and, with the exception of Indiana, these laws are nominally in force. They have not, however, been productive of the best results, - not because the problem involved is not capable of solution, but because the laws have in most cases been framed without sufficient investigation. They fall 
naturally into four groups : 1st, bounties; $2 \mathrm{~d}$, rebates; $3 \mathrm{~d}$, exemption for a period of years; and 4th, exemption of a certain proportion of the area held by an owner. Some States have both bounties and exemption for a term of years.

\section{(1) Bounties}

Illinois, Kansas, Massachusetts and Wyoming offer bounties to forest planters. A bounty in money is offered in order to encourage private owners to plant their nonagricultural lands to forest trees. In some cases the bounty takes the form of a competitive prize for the best plantation in certain districts; in other cases the bounty is paid for each acre of satisfactory plantation.

We made inquiries to ascertain the extent to which this method has proved of value in forest production. Except in the case of Minnesota, so far as the reports are obtainable, they indicate very small results.

In Minnesota $\$ 440,000$ have been spent in bounties, the amount appropriated being $\$ 20,000$ a year. The law has been in operation since 1877. The bounty is at the rate of $\$ 2.50$ an acre. It is claimed by those who are in a position to know that some 50,000 acres of standing timber can be traced directly to the operation of this law. It will be seen at a glance that, although the law has accomplished results, it has done so at an enormous cost.

The Massachusetts bounty laws are treated in detail in Part III. of this report.

The Illinois law is given below as a type of bounty law: -

\section{Illinois Revised Statutes, Chapter CXXXVI.}

Bounty for tree planting.

Three years' cultivation required.

Density.

Proof necessary.
Section 1. It shall be lawful for the board of supervisors or county commissioners' court (board of county commis. sioners) in any county in this state to offer a bounty to any person in said county who shall hereafter plant one or more acres of land with forest trees and properly cultivate the same for three years, for each acre so planted and cultivated: provided, that trees so planted shall not be at a greater distance than ten feet apart each way.

Section 2. Any person claiming the bounty under this act shall make proof before the county clerk that he has complied 
with section one of this act, and that the trees planted by him are in a healthy and growing condition.

Section 3. Upon proof of compliance with this act the certificate. county clerk shall issue his certificate to the person entitled to the same, setting forth that the provisions of this act have been complied with, and the number of acres so planted.

SECTION 4. The board of supervisors or county commissioners' court (board of county commissioners), desiring to Notice of offer offer the bounty herein provided for, shall do so by resolution, to be made of record and giving notice in some newspaper published in the county three weeks prior to the first day of April in each year; said resolution and notice to state the amount of bounty offered for each acre planted and cultivated.

\section{(2) Rebates}

Pennsylvania is the only State which has tried the method of assessing woodlands at their sale value, but offering, under certain restrictions, a rebate upon the taxes paid. Laws of this kind have been in force since 1887, but owing to defects in their phraseology they have not been productive of great results. In order to make them more effective, they were redrafted and re-enacted in the spring of 1905. A sufficient period of time has not yet elapsed to determine the value of the revised laws in promoting forest culture. The laws as re-enacted in 1905 are as follows:-

Act No. 88. To encodrage the Preservation of Forests, BY PROVIDING FOR a REBATE OF TAXES LEVIED UPON Forested Land.

Section 1. Be it enacted, etc. That in consideration of the public benefit to be derived from the retention of forest or timber trees, the owner or owners of land in this Commonwealth, having on it forest or timber trees averaging not fewer than fifty trees to the acre, each of the said trees to measure at least eight inches in diameter, at a height six feet above the surface of the ground, with no portion of the said land absolutely cleared of the said trees, shall, upon filing with the assessor of their respective townships or districts, annually, an affidavit made by said owner or owners or by some one in his, her or their behalf, upon blanks to be provided by the Affidavit of county commissioners of the respective counties, and by them to be furnished to the assessors for the purposes herein in-

Forest preserration.: owner. - 
tended, setting forth the number of acres of timber land within the requirements of this act, be entitled to receive annually, during the period that the said trees are maintained

liebate.

Proviso.

Duties of assessors.

Compensation of.

Act of May 25 . 1897 , and Act of A pril 11, 1901 , cited for repeal.

Rep̧eal. in good condition upon the said land, a rebate equal to eighty per centum of all taxes, local and county, annually assessed and paid upon said lands, or so much of the eighty per centum as shall not exceed in all the sum of forty-five cents per acre; the said rebate to be deducted from said taxes pro rata, and receipted for by the respective tax collectors or county treasurer: provided, however, that no one property owner shall be entitled to receive said rebate on more than fifty acres.

SFCtion 2. It shall be the duty of the assessor, when such affidavit is filed with him, to record upon his assessment book the amount of timber land upon which the owner or owners may be entitled to receive the rebate, together with the value at which such timber land shall be assessed, for the purpose of furnishing the necessary information to those who shall prepare the respective tax duplicates, and upon which duplicates the amount of the said rebate shall be stated. No additional compensation shall be allowed any assessor for performing the duties required by this act. It shall likewise be the duty of each assessor, after receiving such affidavit, to file the same, at the time of making his return, with the county commissioners of the respective counties.

Section 3. The following acts of Assembly, to wit: "An act for the preservation of forests, and partially relieving forest lands from taxation," approved May twenty-fifth, one thousand eight hundred and ninety-seven (Pamphlet Laws, 88 ), "An act to encourage the preservation of forests, by providing for a rebate of certain taxes levied thereon," approved April eleventh, one thousand nine hundred and one (Pamphlet Laws, $r \%$ ), and all other acts or parts of acts inconsistent with the subject matter covered by this act, be and the same are hereby repealed.

Approved the eighth day of A pril, A.D. 1905.

Act No. 179. To encodrage the Planting and the Maintaining of Sprodt Forést and Timber Trees, and PROVIDING THAT THOSE WHO THUS AID SHALL BE EXEMPT From TaXation; Defining the DUties of the Township Assessor of Taxes and Penalties for VioLATION OF THIS ACT.

Forest and timber trees.

Section 1. Be it enacted, etc. That in consideration of the public benefit to be derived from the planting and culti- 
vation of forest or timber trees, the owner or owners of any land or lands in this Commonwealth who shall plant the same with forest or timber trees, in number not less than three hundred to the acre, shall have a rebate in his or her or its Rebate of taxes, to the amount of eighty per centum thereof, thereon, for a period of thirty-five years: provided, That such rebate shall not amount to more than forty-five cents per acre, said period of exemption to be counted from the time the said land or lands shall have been planted with forest or timber trees, as aforesaid, or from the time it may have been necessary to replant the same, as aforesaid, by reason of destruction from fire; and the rebate herein provided for shall be calculated and allowed by the tax collector.

SECTION 2. The owner or owners of any land or lands in this Commonwealth who shall maintain upon said land or Sprout forest or timber trees. lands sprout forest or timber trees, in number not less than three hundred to an acre, shall be entitled to and receive the rebate of taxes as provided in section one; said period of exemption to be counted from the time the said land or lands shall have been so maintained with sprout forest or timber trees, or from the time that said sprout forest or timber trees may have been destroyed by fire.

SECTION 3. Upon any tract or tracts selected as a forest reservation, in accordance with sections one and two of this act, which contain fifty or less original forest trees on each acre, the owner or owners may plant a sufficient number of trees which shall make up not less than the required three hundred trees to the acre, and the same shall become subject to this act, in accordance with sections one and two.

Section 4. No land owner or owners shall receive the benefit of this act who shall permit cattle, horses, sheep, hogs or goats to pasture upon such reservation or reservations, until at least two hundred trees upon each acre of said tract are four or more inches in diameter two feet from the surface of the land.

Section 5. It shall be the duty of the township assessor of taxes to personally examine the various forest reservations, Duties of township and, if found necessary, to demand of the owner or owners, or their agent thereof, to subscribe under oath that the land is maintained under the conditions of this act; and to return to the county commissioners the number of acres so maintained and the time from which the land has been so maintained; and also to make a duplicate return of the same data to the state forestry commission.

SeCrion 6. Any assessor who shall knowingly and wilfully Fraudulent accept and make a fraudulent return, or any owner or agent 
Fine and penalty.

Proviso.

who shall knowingly and wilfully make any fraudulent return to the assessor, shall be liable to a fine of not more than five hundred dollars, or imprisonment of not more than one year, or either or both, at the discretion of the court: provided, however, that the provisions of this act shall not be construed so as to exempt from taxation more than five hundred acres, owned by any one person or body corporate, or limited copartnership or association.

All acts inconsistent with this act are hereby repealed. Approved the twentieth day of April, A.D. 1905.

(3) Exemption for a Period of Years.

Colorado, Connecticut, Maine, Massachusetts, Nebraska, New Hampshire, Rhode Island and Vermont have laws which exempt young forest plantations for a period of years. Answers to our inquiries into the results of these laws were received from Connecticut, Maine, New Hampshire and Vermont. The Vermont law has been in force only since the spring of 1905 , and of course has not had time to show any results. Although the law has been on the statute books in the other States for many years, - in one of them since 1878 , - almost no results are reported. This is accounted for by the fact that in every case the law is at fault in its phraseology. A law which is restricted in its operation to plantations - that is, to artificial reproduction - must necessarily fall short of securing satisfactory results. Such laws, to give good results, must be drawn so as to include young stands produced by natural seeding and sprouting. Moreover, in several instances the specified number of plants per acre is unnecessarily large, and the number of species of tree which may be planted is unnecessarily small, not including some of the best native species. And, finally, the exemption in several instances is restricted to land which has been previously cultivated in field crops. This excludes any possibility of continuity of forest crops from the same parcel of land.

As a type of this kind of law, that of Rhode Island is given:- 
General Laws, Chapter XuIV.

SECTion 3. Whenever there shall have been planted one or Tree planta. more acres of land, worth not more than twenty-five dollars taxed. per acre, in the state, not at the time of planting sprout or woodland, to timber trees of any of the following kinds: Chestnut, hickory, white ash, oak, maple, European larch, pine or ailanthus, in numbers not less than two thousand to the acre, the owner of such plantation of trees may, after they shall have grown to an average of four feet in height, appear before the board of assessors of taxes in any town in which such plantation may be located, and prove the facts above-mentioned and specified in reference to such plantation; and upon such proof, such plantation of trees, and the ground in which they are growing, shall be exempted from all taxation whatsoever for a period of fifteen years next thereafter.

\section{(4) Exemption of a Certain Proportion of the} Area HeLd By aN OWNER

Indiana has tried the above method. The law was lax in its provisions against fraudulent exemptions, but with slight amendments would undoubtedly have produced excellent results. After it had been in force a few years a test of its constitutionality was made, which resulted in its practical annulment. Although unconstitutional in Indiana, it does not follow that it cannot be applied in our own or other States. It is given below:-

\section{Indiana.}

Burns Annotated Statutes, Vol. III., Revision of 1901 (Laws of 1899, PAGE 570).

SECTION 6628a. Upon any tract of land in the state of $\begin{gathered}\text { Private forest } \\ \text { reservations. }\end{gathered}$ Indiana, there may be selected by the owner or owners, as a permanent forest reservation, a portion, not to exceed oneeighth of the total area of said tract, which shall be appraised for taxation at one dollar per acre.

Section 6628b. If such selection is an original forest. containing not less than one hundred and seventy trees in each acre, it shall become subject to this act upon filing with the auditor of the county in which it is situated a description of such selection as is hereinafter provided.

SECTION 6628c. If any land owner shall plant not less Plantations than one hundred and seventy trees on each acre of selected exemptafter 
Replanting to secure exemption.

Cattle must be kept out.

Removal and replacement of trees.

Number of trees to be cut per year.

Forest tree defined.

Record of forest reserva. tions to be kept.

Examination and assessment. forest reservation, and shall cultivate and maintain the same for three years, then it shall become subject to this act, as herein provided.

SeCTION 6628d. Upon any tract selected as a forest reservation which contains one hundred or more original forest trees on each acre, the owner may plant a sufficient number of forest trees which shall make up the required one hundred and seventy forest trees per acre, when the same shall become subject to this act, as in section three.

Secrion 6628e. No land owner shall receive the benefit of this act who shall permit cattle, horses, sheep, hogs or goats to pasture upon such reservation until said trees are four inches in diameter.

Section 6628f. Whenever any tree or trees shall be removed or die, the owner, in order to avail himself of this act, shall plant other trees in place of such trees as may be removed or die, and protect said trees, until they are four inches in diameter, shall plant others which shall at all times maintain the full number required by this act.

Section $6628 g$. Not more than one-fifth of the full number of trees in any forest reservation shall be removed in any one year, excepting that such trees as may die naturally may be removed, when other trees shall be planted.

Section 6628h. Ash, maple, pine, oak, hickory, basswood, elm, black locust, honey locust, Kentucky coffeetree, chestnut, walnut, butternut, larch, tulip tree, mulberry, Osage orange, sassafras, and catalpa, shall be considered forest trees within the meaning of this act.

Section 6628i. It shall be the duty of the auditor in every county to keep a record of all forest reservations as the same shall be filed with him, and he shall require the owner or agent to subscribe under oath the extent and description of the land reserved, and that the number of trees is as required by this act, and that he will maintain the same according to the intent of this enactment.

Section 6628j. It shall be the duty of the assessor to personally examine the various forest reservations when the real estate is appraised, and to note upon his return the condition of the trees, in order that the intent of this act may be complied with. And if the reservation is properly planted and continuously cared for, he shall appraise the same at one dollar per acre. 


\section{Part III - Massachusetts}

The Commonwealth of Massachusetts has tried two methods of tax relief, - bounties, and exemption of plantations for a period of years.

The first attempt to promote forest culture dates back to 1818 , and was evidently intended to provide against a famine in ship timber. It is given in Revised Laws, chapter 124, as follows:-

Section 10. Every such society shall annually offer such premiums and encouragement for the raising and preservation of oaks and other forest trees as it considers proper and Premiums for raising adapted to perpetuate within the commonwealth an adequate forest trees. supply of ship and other timber.

The records show that in all $\$ 36,336.75$ have been offered and $\$ 3,375.20$ awarded. Of the funds offered, $\$ 12,000$ were supplied by the Massachusetts Society for promoting Agriculture; and of those awarded, $\$ 2,000$ were paid by this society; making in all $\$ 1,375.20$ awarded by the Commonwealth. No record of the acreage planted has been made; and the probability is that most of the contests were in ornamental rather than economic planting.

We believe that this law is inadequate to solve the problem of economic forest propagation within the Commonwealth. For, granting that it has secured the planting of considerable areas, which it has not done, these forests would under the present system of taxation be subject to an annual and increasing assessment, which tends towards early and wasteful cutting.

The next law intending to promote timber culture was passed in 1878. It provides for exemption of artificial plantations for a period of years. This law is as follows:- -

\section{Revised Laws, Chapter 12}

Section 6. All plantations of chestnut, hickory, white ash, Plantations of white oak, sugar maple, European larch and pine timber trees, in number not less than two thousand trees to the acre, upon land, not at the time of said planting woodland or sprout-land 
and not having been such within five years previously, the actual value of which at the time of planting does not exceed fifteen dollars per acre, shall, with such land, be exempt from taxation for a period of ten years after said trees have grown in height from four feet on the average subsequently to such planting, upon satisfactory proof by the owners to the assessors of these facts; but such exemption shall not extend beyond the time during which said land is devoted exclusively to the growth of said trees.

This law is deficient in many ways. The number of trees required is too large. By limiting the relief to the few species named, an owner is not left a free choice in selecting species best suited to his soil and the local market. By limiting its application to lands that have once been cultivated or in pasture, the law does not tend towards a systematic treatment of existing woodlands, an end of far more value to the Commonwealth than the increase of the actual area covered by woods, the area in woodlands already amounting to half its total area. Moreover, the operation of such a law in a State like Massachusetts, which, with the exception of portions of the Cape, is potential forest land, where the conditions of natural reproduction are generally good, would be to put a premium on artificial reproduction, which as a rule is more expensive than the natural methods. In other words, the tendency of the law is to interfere in reproduction, which is purely a matter of silviculture, and should be secured by the method which the conditions on a particular tract in a particular locality would make advisable.

The law has been a failure, as practically no planting has been done under it.

The last law is found in chapter 409 of the Acts of 1904:-

Section 3. The state forester may establish and maintain a nursery for the propagation of forest tree seedlings on such lands as the trustees of the Massachusetts Agricultural College may set aside for that purpose on the college grounds at: Amherst. . . . He may distribute seeds and seedlings to land- 
owners, citizens of the Commonwealth, under such conditions and restrictions as he may, subject to the approval of the governor and council, deem advisable.

The State Forester has established the nursery under the authority given in the law cited above, and will distribute material from it on the following conditions, which have been approved by the Governor and Council:-

1. Not more than 2,000 nor less than 1,000 will be furnished to any applicant in one year, except to dispose of an odd lot.

2. The price shall be as nearly as can be determined the cost involved in the production of the seedlings.

3. Applicants must operate under a planting plan, a copy of which has been placed on file with the State Forester, and which has received his approval.

This provision is in effect a bounty, since the plants are furnished at cost prices. As far as it goes, and with the safeguards that have been placed about it, it will be productive of good results; but, as pointed out in connection with the plantation law, it does not give relief toward the later growing stages of a forest crop, and therefore it is not a solution of the taxation problem.

Why the Method of taxing Forest Lands should be MODIFIED

There are 2,688,000 acres of woodlands in the Commonwealth. They are producing per annum only $\$ 3,454,000$ worth of merchantable material, delivered. If we add to the area now classified as waste land the area in woodlands, and make liberal deduction for errors in classification, and also make a liberal deduction for lands unfit for forest growth, there would be at least $3,000,000$ acres that are available for forest purposes. If this entire area were under proper forest cultivation and management, presumably it would produce several times as much wood and timber as it produces at present.

The tendency of the present law tax is towards early cutting, and neglect of cultivation. A reform, therefore, 
that would lead to a more conservative method of cutting, and careful cultivation, is of great importance not only to land owners but to all of our industries that consume wood.

The present method of taxing woodlands is an important factor in keeping their output at a low figure. We have had convincing evidence of this fact.

The most objectionable feature of our system is that it provides for taxing the value of the growing crop, as well as the land upon which it grows. In the case of an ordinary agricultural crop, the value of the crop is not taxed. The soil is assessed at a fair, average figure; but the growing wheat, grass, turnips, potatoes, or other crop which may be on it, is not reckoned in the valuation, except in so far as it may indicate the fertility of the land. But in the case of wood or timber crop the land is taxed, and, in addition, the growing crop is taxed, not only once or twice, but year after year, at an increasing valuation until it is cut, when the valuation is reduced to that of the land without the crop. The consequence is that the owner is led to cut his crop before it has reached its productive maturity; that is, its greatest value to himself and to the State. While the tax on the crop may not seem large in any one year on a given parcel of woodland, it acts as a strong influence through a long series of years, and this influence is hostile to the forest and its proper management. The more capable and faithful the assessors are, under the present law, the more effective the law becomes in causing premature harvesting of the forest crop. Such a tax hinders the increase of wealth by cutting it off at its source. And, aside from the economic question involved, it discriminates against forest crops as compared with field crops, giving a decided advantage to field crops. In this respect it is not fair.

Another objectionable feature of the present system is that it taxes the property at a time when it is not bringing in any income. When a crop may be from a quarter to a half century in maturing, it is a hardship on the men to make payment during the intervening years. This accentuates the tendency towards cutting immature timber. 
If the desirability of property as an income-bearing, private investment be taken as an indication of the proportion of the tax burden which it ought to bear, woodlands ought not to be taxed proportionately more than ordinary agricultural lands. Although a sharp buyer may trade in woodlands that have mature timber on them, and make on the investment, yet to buy land and to grow the crop is not a good investment, except perhaps for surplus funds, for three main reasons: first, because of the long period of time which must elapse before the crop matures; second, because the property is not readily salable at full value during that period; and third, because the crop is exposed to injury from fire, storm, fungous and insect ravages.

And, if the amount of protection which the property receives from the State and community be taken as an indication of the proportionate amount of the tax burden which it ought to bear, woodlands ought to bear less than many other forms, instead of more, as they now do. We can find no record of an insurance company which has taken a risk on standing timber in the Commonwealth. We have found only one company which quotes a rate, and that rate is $\$ 6.25$ on $\$ 100$, - a rate which exceeds the average of growing timber, and which is, therefore, prohibitive. From the point of view of protection, woodlands now bear far more than a fair proportion of taxes.

\section{Recommendations}

In view of the facts above recited, we recommend:1. That the laws relative to the taxation of woodlands in this Commonwealth be amended in such a way as to relieve the crop from taxation, except a fair rate of taxation on the average annual cut; that the value of the land without the crop be assessed as cut-over land; and that the value of the average annual cut* in cords or board

* The average annual cut is equivalent to the average annual growth or production, in the long run. In under-stocked woods it is less, and in overstocked woods it is more, than the growth, until equilibrium is restored. The purpose of the recommendation is to secure to the town in which the woodland may be situated a revenue from the product the year it passes into personalty, in which form it may leave the town, county, or State. 
measure, which the forest might advantageously bear, be assessed and added to the value of the land, - the sum to be the total assessment.

2. That the law be restricted in its application to woodlands which the owner agrees to manage under a forest working plan, which (1) fixes the average annual cut, (2) has been approved by the State Forester, and (3) is subject to his inspection; that the working plans be revised at least once in ten years, or the owners forfeit their privileges; that the owners bear the expenses of the preparation, inspection and revision of working plans under the same regulations that now govern applications to the State Forester for practical assistance; that the law be restricted in application to 100 acres or less held by any one owner, whether individual or corporate, and to 200 acres located in any city or town, in any one year; and that the law be restricted to lands valued at $\$ 20$ and under per acre, exclusive of the crop.

\section{In Operation}

A law based on the above principles would be effective and simple in operation. Suppose an owner has 50 acres of land, 30 acres in woodland and 20 acres of abandoned fields, which he wishes to bring under the operation of the law. He has a working plan made for the tract. The working plan (see Appendix) shows that 20 cords of white pine and 15 cords of hard wood may be cut annually from the stand without over-cutting. The State Forester sends a statement of the average annual cut to the assessors, together with a map or plan showing the location and extent of the lands. The assessors would make up their valuation in the following manner:-

50 acres of land, without wood, at $\$ 5, \quad$. . . . $\$ 25000$

20 cords of box boards, at $\$ 5$ on stump, . . . . 10000 15 cords of hard wood, at $\$ 1.50$ on stump, . . . . 2250

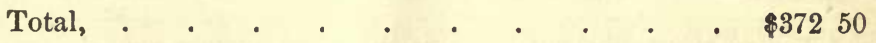

Under the old method the valuation would probably be two or tree times as much. 
The tendency of the law would be to encourage owners to put their lands under a conservative system of forest management. This would mean an increase in the amount of standing timber, and eventually an increase in the amount of the annual cut. In this way a part of the amount taken out of the lists would be restored within a few years, and in time the full amount would be replaced. The benefit to our industries given by a home supply of timber would increase the amount of taxable property in other forms. The town and Commonwealth would be benefited in the end, although the application of the law would mean a temporary though not a large reduction of asseșsment.

The law would also have a decided educational tendency. It would awaken interest in the subject of forestry, and lead to a better management even on lands not affected directly by it.

The provision that the law be restricted in its application to lands worth less than $\$ 20$ for other purposes would prevent a misapplication to lands that should be under farm crops, or should be used as building lots.

The restriction of the law to 100 acres belonging to any one owner would prevent any possibility of large owners and wealthy corporations getting an advantage over the small owners and farmers; and its restriction to 200 acres in a town or city in any one year would prevent any possibility of a burdensome or even an appreciable reduction in the town tax lists.

Respectfully submitted,

WOODWARD EMERY, Chairman. JOHN BURSLEY.

JAMES S. RUSSELL.

WILLIAM D. T. TREFRY.

GEORGE S. LADD.

CHARLES H. SHAYLOR.

ALFRED AKERMAN, Secretary. 



\section{APPENDIX}

Condensed Working Plan Report on the Woodlands of John Doe, Esq., by Richard Roe, Forest Engineer

\section{Working Plan}

The following working plan is for 50 acres of woodland, situated in the town of Doeville, and owned by John Doe, Esq.

\section{Object of the Owner}

It is the desire of the owner to manage his woodlands in such a way as to make them produce continuously the greatest amount of wood and timber, with the least possible expenditure. He is particularly anxious not to cut the standing timber at a greater rate than that at which it is growing.

\section{Treatment}

For purposes of description and treatment, the tract has been divided into blocks, which are indicated on the accompanying map.

Block No. 1 is 5 acres in extent. It is covered with a stand of mature white pine ready to cut, which when surveyed was found to amount to 200 cords fit for box boards and cheap lumber. It is recommended that this lot be cut over after the next heavy seed year, and that the natural seeding be supplemented by planting if necessary.

Block No. 2 is 10 acres in extent. It is covered with a younger stand of white pine than that on Block No. 1. The stand as surveyed amounts to 250 cords. This stand should be thinned moderately, to improve and increase the growth.

Block No. 3 is 20 acres in extent. It is an old field, which is coming up to scattering bushes. It is recommended that it be planted to white pine and red oak in mixture.

Block No. 4 is 15 acres in extent. It is covered with a growth of chestnut, red oak, ash, maple and birch. The survey places the stand at 300 cords. This block should be thinned moderately, to improve the growth. 


\section{Annual Cut}

The owner may with perfect safety cut 20 cords of pine and 15 cords of hard wood a year. It is not necessary, nor is it desirable, that this exact amount be cut each year. The cut of several years may be taken in one, if the work can be done cheaper in that way, or the condition of the stand demands it; but over a series of five to ten years the average cut should not exceed the above amount.

Note. - Twenty cords of pine and 15 cords of hard wood would be turned in to the assessors as a basis for taxation under the proposed method, whether the owner cut that amount or not. 
Commontwealth of attassarburetts

STATE FoRESTER'S 0FFICE

\section{PRACTICAL SUGGESTIONS}

FOR THE

\section{Massachusetts Tree Planter}

BY

\section{RALPH C. HAWLEY, M.F.}

ASSISTANT STATE FORESTER

SECOND EDITION

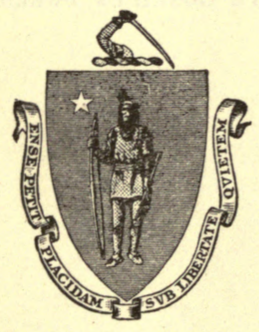

BOSTON

WRIGHT \& POTTER PRINTING CO., STATE PRINTERS

18 Post Office Square 


\title{
MassachusetTs State Forest Service
}

\author{
Alfred Akerman, M.F., State Forester \\ Ralph C. Hawley, M.F., Assistant State Forester \\ Walter K. Fobes, Clerk
}

\section{APPROVED BY}

The State Board of Publication 


\section{CONTENTS}

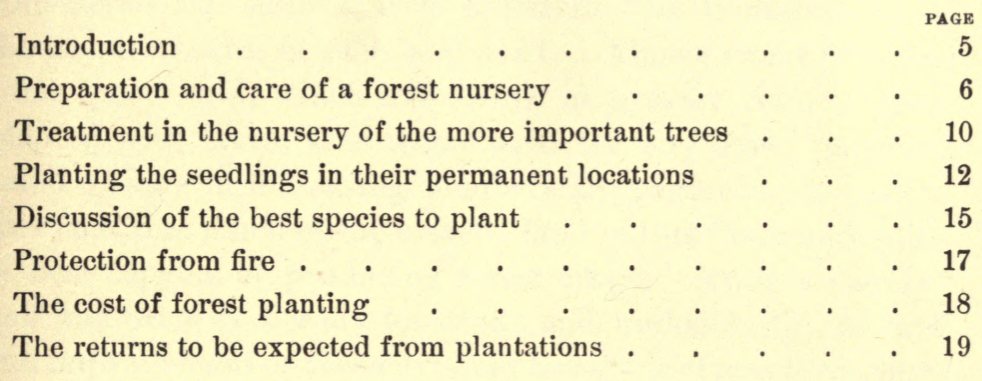

Appendix : Diagram to scale of a small nursery ; with a statement of its capacity for white pine, chestnut, red oak, white ash, and sugar maple seedlings $\quad . \quad$. $\quad . \quad . \quad . \quad 23$ 



\section{PRACTICAL SUGGESTIONS FOR THE MASSACHUSETTS TREE PLANTER}

\section{INTRODUCTION}

Just how many acres of land, capable of supporting forest growth, are lying idle throughout the Commonwealth, it is impossible at this moment to state. But to those who have considered the subject, it is apparent that thousands upon thousands of acres of such land exist. Almost every farm has some poor land, which will bring in greater returns when planted with trees, than when used for any other purpose. Land owners in increasing numbers are beginning to realize this fact, that much of the cleared land in this Commonwealth is best capable of producing forest crops. Approximately, half the State is already forested; and undoubtedly the care and improvement of these existing forests is of greater importance, than the planting of bare areas. But circumstances in individual cases often reverse this relation, bringing it about, that forest planting becomes the line along which many landowners can best work, in practicing forestry, and in developing the latent resources of their land. To emphasize this fact and to provide information, sufficient to answer many of the numerous questions which are continually being received by the state forester relative to the planting of forest trees, is the purpose of these pages. No claim to originality is made as regards the subject matter, which is mainly a compilation of facts already well known by forest tree planters; nor have all phases of forest planting been considered.

The method pursued in treating the subject has been to select the five species of trees which are best adapted for planting in Massachusetts, and to confine the discussion of forest planting entirely to these five trees. 
These species are:

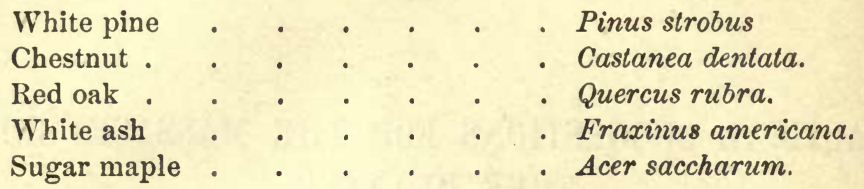

It should be stated that the greater part of what is said about white pine will also hold true of other conifers. In like manner, chestnut and red oak will serve as examples of the nut-bearing hardwoods; while the treatment advised for sugar maple and white ash is very similar to that required by most other species of hardwoods. If, however, information is desired concerning the treatment of any species not specifically mentioned, it can be obtained on application to the state forester. Bulletins No. 29 and No. 45, entitled "The Forest Nursery" and "The Planting of White Pine in New England", issued by the U. S. Forest Service also give valuable information in regard to many points not treated here in detail.

\section{Preparation and Care of a Forest Nursery}

The first step toward the establishment of a successful forest nursery is the selection of a suitable location on a level or gently sloping piece of land. Northern and eastern exposures furnish more favorable situations than southern and western aspects, and the soil, which may be loamy or even slightly sandy, should be well drained but yet contain a fair supply of moisture. If the nursery can be located within or near a forest, or in the shelter of a windbreak, it will be advantageous to choose such a situation.

The preparation of the soil should be the same as for an ordinary garden. While forest tree seedlings will often grow on poorly prepared land, yet any extra time and labor spent in carefully working over and pulverizing the soil will be amply repaid by the increased thrift of the seedlings.

When the soil is thoroughly prepared, the nursery should be laid out in beds and paths. The usual width for nursery beds is four feet, for beds wider than this are hard to weed. 
The size of the nursery is the only limit to the length of the beds, and they may conveniently be several hundred feet long. Between the beds two-and-a-half to three feet should be left for paths, which should lie three to four inches below the surface of the beds. The actual construction of the beds is similar in all ways to that of a garden bed.

The preliminary preparation of the soil can be done either in the fall or in the spring, though it is often advisable to have the land at least plowed in the fall; but the making up of the beds should not be done until spring. As soon as the beds and paths are in shape, the nursery is ready for sowing. This process is discussed farther on in detail for the several species, and need not be considered here.

Each bed after being sown should be gone over with a small roller, or else have the soil firmed with a board or a hoe. Ordinarily the seeds of forest trees germinate and start to develop within the forest, and usually under a cover of leaf litter or duff. For this reason in the forest nursery it is necessary to approximate the conditions found in nature and to furnish the seeds with a protecting cover, which, by preventing rapid evaporation will conserve the soil moisture indispensable for their germination. A mulch of leaves or straw is customarily used for this purpose. This mulch should be thickly spread over the beds, soon after they are planted, and allowed to remain until the seedlings appear. It is important that the beds be frequently examined during this period, and the mulch be removed as soon as the seedlings break through the soil; or the shoots will be dwarfed, perhaps smothered completely. After the mulch is removed and the seedlings well started the beds will require weeding at more or less frequent intervals. Where the young plants stand too thickly they must be thinned out. It may very likely happen, that the seedlings will need watering during the course of the summer, for, while tree seedlings are not so greedy in their demands for moisture as many herbaceous plants, yet in dry spells they should be watered. With this contingency in view, it is always well to locate the nursery within reach of a supply of water.

On the approach of winter the beds should be covered 
again with straw or leaves, since if left unprotected, the seedlings may be killed by the cold or heaved from the ground by the frost. In the spring of course the covering is removed.

\section{Collection and Storage of Forest Tree Seeds}

\section{(a) White Pine}

White pine is an intermittent seed-bearer, the same tree yielding a full crop of seeds on the average only once in every three to five years. The bearing years vary locally to some extent, so that a crop may be produced in one section even though entirely lacking in others. Because of their infrequency it is well to look up a seed year in advance. As the cones appear on a white pine tree more than a year before the seed is ripe, the collector can easily tell, a long time in advance, when a seed year is due and lay his plans accordingly.

White pine cones open about the 15th of September in this State, allowing the two winged-seeds at the base of each scale to be shaken out by the lightest breeze. Unless the cones are gathered before they open, a very small proportion of the seeds can be secured. The collector should, therefore, pick the cones during the last week of August or the first week of September.

After collection, the green cones must be allowed to dry and open. They can be spread in thin layers on papers on an attic floor; or dried in some similar manner. But where large quantities of cones are collected shallow trays with woven-wire bottoms, or a lattice work frame can be economically used. The cones placed on these trays open when dry, and the seeds fall through the bottom into receptacles placed to receive them. To shake out any seeds which do not drop out of themselves, the cones should be beaten. As a final step, the seeds must be cleansed from dirt and impurities by being run through a fanning mill. The clean seed should then be placed in paper sacks and hung up in a dry, cold place, in a barn or shed, for instance, and left there till the time for planting in the spring. Frequently it will pay the planter to buy seed rather than go to the trouble of collect- 
ing it himself. White pine seed varies in price from $\$ 1.50$ to $\$ 4.00$ a pound, according to the supply available. There are over 28,000 seeds in a pound of white pine seed; and the planter may expect to raise on the average about 10,000 seedlings from a pound of seed.

\section{(b) Chestnut}

Chestnuts may be gathered any time in the fall after the burrs open. Until the middle of November, the nuts should be spread out in shallow piles, where they will not become heated. When possible, place them on a dry dirt floor. From time to time they should be examined and, if found to be moulding, the piles should be spread out more; if the nuts appear to be drying out and shrinking in size, place them in a cooler place on the ground. Before the ground freezes, the nuts must be taken up and placed out of doors for the winter in a shallow pit. For this purpose, select a well-drained spot and dig a trench from three inches to a foot deep, depending on the quantity of nuts to be stored. Place the nuts in this pit, in layers two or three inches thick and separate the layers by an inch or two of sand. If pure sand cannot be obtained, layers of leaf litter will answer the purpose equally well. Over the top put on a cover of sand or earth to the depth of six to twelve inches. Beyond occasional inspection of the pile to see that no animals are digging in to get at the nuts, no more work is needed until the nuts are dug up to be planted.

\section{(c) Red Oak}

Red oak acorns are ready to gather in September and October. The directions for gathering and storing chestnuts will apply also to red oak acorns.

\section{(d) White Ash}

The seed of white ash should be collected in October and may be stored for a few weeks in a dry but cool place. But by the middle of November, the seed should be buried six inches or a foot under ground, for the winter, in a well- 
drained situation. Owing to the smallness of the seeds, they are most easily handled when enclosed in strong cloth bags. These bags, when placed in the ground, should be surrounded by sand or leaf litter with a thick layer of earth over all, and left underground until spring.

\section{(e) Sugar Maple}

Sugar maple seeds should be collected in October, and cared for in the manner advised for seeds of the white ash.

Treatuent in the Nursery of the More Important Trees

The best time to plant the seeds is in the spring. This applies to all the trees considered. As soon as the ground is dry enough to work, the seed beds can be made up and the seeds planted; but no planting should be done when the soil is either excessively wet or very dry.

A general rule, in planting forest tree seeds, is to cover them with dirt from two to three times the thickness of the seed.

\section{(a) White Pine}

White pine seed can either be sown broadcast over the bed, or it may be sown in drills. As it is very difficult in sowing broadcast to secure an even distribution of seed, the method of drills is to be preferred. Moreover, the seedlings grown in rows are more uniform in size and usually stronger than those raised from broadcast sowing. The drills may be from six to twelve inches apart, while the individual seeds in each drill should be spaced, on the average, not more than three to an inch.

White pine seedlings, in common with those of other conifers, require partial protection from the sun during the first few years of their life. In nature, the proper amount of shading is furnished by the larger trees and by the ground cover. In the nursery, screens of lath are customarily employed to give the necessary protection.

The screens may be made by nailing laths on a frame four feet wide and of any convenient length. Between each lath 
an open space should be left, equal to the width of a lath; so that the completed screen affords a half shade. To raise the screens above the plants, posts are required. They should be long enough to keep the screens about eighteen inches from the surface of the beds. Screens set on posts high enough to permit a man to work beneath them can be used if desired. If this is done some protection on the sides exposed to the sun should be afforded the seedlings.

As soon as the seedlings appear above ground, the screens are placed over the beds on the posts and removed only on cloudy days, after very wet weather, when it is desired that the beds be dried out. In the fall, when the seedlings are mulched, the screens may be laid on the beds to hold down the mulch.

White pine seedlings should be protected by screens, during their first two summers in the nursery. If they are allowed to remain a third summer in the beds, no shading will be required.

Ordinarily, in the spring of the third year, the seedlings can safely be taken up and set out in their permanent location. If they were kept longer in the nursery, the greater part of them would have to be transplanted and given more room. This largely increases the expense of raising the stock, making it advisable in establishing commercial plantations to take the plants from the nursery when only two years old. Until the seedlings have attained that age, they usually do not need to be transplanted. In some cases, if the plants should come up too thickly in the rows, some of them might have to be transplanted when one year old. This would not be necessary, unless they stood closer than an inch apart.

The chief enemy of white pine seedlings is a fungous disease known as "damping off." It attacks the seedlings when they are only a week or two old and is to be feared in wet, muggy weather. The disease shows itself in a wilting of the young plant. To prevent its occurrence, the nursery beds should be well drained and no water allowed to stand around them. "Damping off" does not attack the seedlings of broadleaved trees so frequently as those of conifers. 


\section{(b) Chestnut and Red Oak}

Chestnuts and red oak acorns, when taken up from their winter storage, should be looked over and the bad ones removed. These cannot always be distinguished from good ones but a large percentage of the bad ones can be detected at this time. The nuts and acorns may be planted in rows about a foot apart and one to two inches apart in the rows. No protection from the sun, such as that afforded white pine seedlings, is required for chestnut and red oak.

Their seedlings grow rapidly and are ready for planting at the end of one year. At that time, they are anywhere from six to eighteen inches high and make excellent planting stock.

\section{(c) Sugar Maple and White Ash}

Sowing in drills a foot apart is recommended for white ash and sugar maple seeds. In these drills, the seeds should be strewn at the rate of four or five to the inch. On account of the wings attached to the seeds, they are hard to sow evenly. For these two species artificial shade is unnecessary, and the seedlings are of the proper size for planting after one year in the seed beds.

\section{Planting the Seedlings in their Permanent Loca-} TIONS

Seedlings may be taken from the nursery beds and planted, either in the fall, or in the spring. Those planted in the fall are often heaved out of the ground by the frost, and are more easily injured by the winter storms than those set out in the spring. In most cases, the work should be done early in the spring, during the month of April or early in May. If possible cloudy, or even rainy weather, should be selected as the time to do the planting.

One of the most important things to remember in setting out seedlings is that their root systems must not be allowed to dry out during the process of removal from the nursery to the planting site. In order to make sure of this, the planter is advised to observe quite closely the following method of procedure. 
First. Dig up in the seed beds all the seedlings that are to be planted, taking care not to bruise or break their root systems. The seedlings should never be pulled up.

Second. Have ready a tub or pail of water, thickened with loam or clay. As fast as the seedlings are dug up, tie them in bundles of 25 to 100 seedlings and dip the bundles into the muddy water, in order that the roots of the seedlings may become thoroughly coated with a film of mud. This is known as "puddling" and will hinder the drying out of the root system.

Third. Prepare a narrow trench 6 to 12 inches deep, cut down on a slant, and, just as soon as a bundle of seedlings has been puddled, place it in this trench with the roots down and cover it with earth, up nearly to the tops of the seedlings. When all the bundles have been " heeled in" in this way, they can safely be left (for several weeks if desired) until wanted for planting.

Fourth. If the nursery is close to the land to be planted, the bundles of seedlings can be taken from the trench as wanted. But the planting site may be several miles distant from the nursery. In this case the bundles of seedlings may be wrapped in sphagnum moss, rolled up in wet burlap, or packed in any way which will keep their roots moist, and taken to the planting site, where they should again be " heeled in" to be removed by the planter a few bundles at a time.

Fifth. When taken out to be planted, each bundle should be placed in a pail partly filled with mud and water, or in a basket filled with wet sphagnum moss. From the pail the seedlings may be taken one at a time and planted, thus insuring that the roots shall be wet when finally placed in the ground.

The actual work of planting can be accomplished handily by a crew of two men; one making holes for the plants with a few strokes of a mattock, and another who follows him with the plants setting them out. Another good way is for each man to plant seedlings in the holes he himself makes. The planter should take care to place around the roots of each seedling mineral soil comparatively free from leaves or rubbish of any kind, and to firm the soil down well; for no 
air spaces must be allowed around the rootlets, or fatal drying will result.

The distance apart at which the seedlings are to be set out will vary somewhat with the objects sought from the plantation. A spacing of six feet apart each way is ordinarily the one to adopt for commercial plantations in Massachusetts; though where rough box lumber alone is desired a wider spacing may often be employed to advantage. When spaced $6 \times 6$ feet, 1210 plants are needed to stock one acre.

Once a year, during the first two or three years after its establishment, the plantation should be looked over and if large groups of seedlings have died they may be replaced by fresh plants. Beyond planting up blanks caused in this way the plantation, until it becomes ten to twenty years old, will require no care except protection from fire. For information as to the care of a plantation more than ten to twenty years of age, the reader is referred to Bulletin No. 2 of this office.

There are certain species of trees whose seeds can successfully be planted on the land where they are to remain permanently, thus doing away with much of the trouble and expense which is unavoidable when seedlings are bought or raised to be set out on the planting site. Of the species considered in this pamphlet, chestnut and red oak are such trees. Their nuts and acorns, instead of being sown in a seed bed, may be placed two in a hill on the land to be planted; the holes to be spaced $6 \times 6$ feet, just as though seedlings were being planted.

As the expense of establishing a plantation of chestnut or red oak is greatly lessened by planting the nuts or acorns instead of the seedlings, it is advised, that the former method be employed for these two species, whenever the proposed planting site is fairly clear of bushes and sprout growth. When the land is already covered with bushes or young sprouts, however, it will often be expedient to go to the greater expense of planting the seedlings.

The sowing of white pine seed broadcast, over a field or pasture, in the majority of cases results in failure to establish a satisfactory crop of seedlings. Even where seed spots 
about a foot square are prepared and the seed is sown on these spots in contact with the mineral soil total failure may result; for, while cheaper than planting seedlings, it cannot be depended upon to give such good results as the latter.

\section{Discussion of the Best Species to Plant}

In choosing the tree or trees to be planted, in each case, the principal things to be considered are these :

First. Whether the species is suited to the climate of the region where the planting is to be done.

An affirmative answer may be given to this query, if the tree already grows in the locality. But, on the other hand, the fact that the tree may not now grow in the region does not necessarily prove that it will not thrive when once introduced. In general it may be said that white pine, white ash, and sugar maple, may be planted in all parts of the State, except Barnstable, Dukes, and Nantucket counties. In these three counties there may be small areas where the above-named trees will thrive. Red oak has a somewhat more extensive range for planting as it will grow throughout the State, even in most sections of the three counties mentioned. Chestnut while having the same general range as these other species, prefers a somewhat warmer climate. For this reason, in certain localities in the extreme northeastern and western portions of the State, chestnut should not be planted in cold or exposed situations.

Second. Whether the soil and moisture conditions are favorable for the growth of the species chosen.

For instance, even in a region well adapted to a certain species, the soil conditions over small areas may be such as to prevent its development. White pine will grow on soils of all sorts, the chief requirement being that the soil shall be well drained. The tree prefers gravelly sands with a clay subsoil which insures a supply of water not far from the surface. Swamps and low marshy land are not suitable places for planting white pine.

Chestnut also grows only on well drained soils of at least moderate fertility; otherwise its demands made upon the soil are not hard to satisfy. Red oak and sugar maple need a 
deep fertile soil, with a fair amount of moisture, for their best development, and should be planted only on the better class of forest soils. White ash thrives on deep, moist, fertile soils, the moisture being the governing factor. White ash is adapted to planting in swampy situations, wholly unsuited to the other species mentioned. But it should never be planted in swamps where standing water remains for many months in the year. Notwithstanding its liking for wet locations, white ash grows well on the soils suited to the red oak and sugar maple.

Third. The character of the wood which the plantation will yield.

If several species can be successfully planted on a given tract, the product which the owner wishes to obtain from the plantation will usually determine the species to be chosen. In case fuel wood is desired, sugar maple or red oak will be the best trees to plant. White pine, of course, will lead as a producer of lumber and boxboards. For ties, poles, and posts, chestnut should be planted; while white ash furnishes valuable stock for wood working purposes. These few examples will serve to show that the nature of the future product should be considered before starting a plantation.

Another question which will arise is whether the plantation shall be made of only one species or shall be a mixture of several different species. White pine, chestnut, red oak, white ash, and sugar maple, may each be planted pure (i.e., separately) or in mixtures, on situations adapted to the species composing the mixture. It will depend upon the wishes of the owner as to which kind of a forest is started. The chief advantage of a forest composed of only one species is that it can be more easily managed than one containing several species. A mixed forest, however, allows the owner to better adapt the product of his forest to the demands of the market, since he has several different kinds of wood to sell. The danger of bad fires and of ravages by insects and fungi is less in mixed than in pure forests.

In establishing a mixed plantation, the species may be mixed in several ways. The mixture can be by single trees, or by irregular shaped groups of the different species. Still 
another desirable method is to have the species alternate by rows. But a discussion of the various possible arrangements cannot be taken up here; and anyone wishing further information for a specific case is advised to communicate with the state forester.

\section{Protection from Fire}

Of all the dangers to which a forest plantation is exposed, fire is the greatest. Insects, fungi, and natural factors, such as storms and droughts, - frequently occasion losses among the young plants. But the damage done usually extends over only a small portion of the area planted and can be repaired at comparatively little expense.

A forest fire, however, if it once gains headway, may sweep over the entire plantation, entailing a total loss. This fire hazard of course is greatest while the plants are young, but is present in decreasing amount throughout the life of the forest. Every landowner, before establishing a plantation, should seriously consider the problem of fire protection. If protection can be secured at a reasonable cost, the plantation may be established; but if protection from fire can be obtained only through large expenditures, the idea of planting should be abandoned.

As a matter of fact, fire protection in a majority of cases can be secured very cheaply, when once the attempt to do so is made.

Efforts to protect a plantation from fire must vary in individual cases, but will be along two main lines, as follows:

(a) Toward the construction of fire lines.

(b) Toward patrol of the plantation.

By a fire line is meant a narrow strip of land, a few feet wide, bordering the area to be protected, and kept clear of all inflammable material. A roadway or else a plowed strip make the best kind of fire lines. Where the ground cannot be ploughed, all dead branches and leaves should be removed and the fire line burned over occasionally to keep down the grass. The ordinary surface fire will not pass such a fire line, which can be constructed for $\$ 10.00$ a mile as the maximum cost. 
Where the area to be protected is of considerable extent, it may be wise to have a man keep watch of, or patrol, the plantation during the dry seasons in each year. Unless the tract contains several hundred acres or more the cost of such a patrol would be excessive, where paid for outright. But small landowners are often so situated that they can keep watch of their plantations themselves, without great inconvenience, thus obtaining fire protection at small cost. When the owner has become convinced that he can secure adequate fire protection for his prospective forest plantation, and not until then, is he ready to think seriously of planting.

\section{The Cost of Forest Planting}

The expense of establishing a forest plantation falls under two heads :

(a) The cost of the planting stock delivered on the ground.

(b) The cost of actually setting out the plants.

\section{(a) The Cost of the Planting Stock}

There are several ways in which planting stock can be obtained. Seed may be gathered or purchased and the seedlings raised in a nursery by the planter; or the seedlings may be bought outright from a nursery. Wild seedlings may be dug up in the woods and planted. In the case of chestnut and red oak, the nuts and acorns can be directly planted, greatly lessening the amount expended for stock and also in planting it. Then, the cost of seed and seedlings varies with the different species, white pine being more expensive than the hardwoods. Moreover, prices of forest tree seeds and seedlings differ greatly from year to year. For these reasons, no attempt will here be made to give the exact cost of obtaining planting stock. It may safely be stated, however, that where seedlings are to be set out $6 \times 6$ feet apart, requiring 1210 plants per acre, the cost of obtaining planting stock will range from $\$ 2.50$ to $\$ 6.00$ per acre. The upper limit will be approached when nursery 
stock is bought, especially where white pine is to be used. The outlay will approximate the lower figure, when, the seedlings are gathered in the woods or raised in a nursery by the planter himself.

\section{(b) The Cost of setting out the Plants}

The price of labor and the nature of the land to be planted, will largely determine the expense under this head. On very rocky land, or fields thickly covered with vines and brush, the cost of setting out the plants might easily run up to $\$ 10.00$ an acre. But on the average this work can be done for from $\$ 3.00$ to $\$ 4.00$ per acre, allowing 1210 plants to the acre.

The total cost then of establishing a forest plantation will, under average circumstances, vary from $\$ 5.50$ to $\$ 10.00$ per acre. Where the planter does a large part of the work himself, instead of buying material and hiring labor, the actual outlay in money may be reduced below the minimum amount given.

\section{The Returns to be expected from Plantations}

Forest planting, like most other forest operations, requires the investment of money to yield returns only at the end of several decades. Before thus tying up their money, it is natural that landowners should desire to learn the returns which they may reasonably expect from plantations of forest trees. In attempting to estimate the returns, the total amount of the investment must first be ascertained. This is made up of several items.

1. The cost of the planting.

2. The value of the land.

3 . The annual taxes.

4. The cost of fire protection.

All four should be figured with compound interest until the crop is harvested.

To show what these items amount to at the end of a definite period ( 40 years), the following table has been computed, for land of three different values, and for three dif- 
ferent planting costs. Taxes were reckoned at $2 \%$, and all calculations were made with $4 \%$ compound interest. The table gives the entire investment per acre, at the end of 40 years, which a man would incur in establishing a plantation; except that the cost of fire protection has not been included. This is a factor which cannot be computed except in each individual case. But for the purpose of this discussion, we may safely assume that it will never, at the end of 40 years, have accumulated beyond a maximum of $\$ 10.00$ an acre. So to the total figures in Table I. should be added in each case $\$ 10.00$. They will then show the total investment per acre in the plantation.

After adding the fire protection cost, these figures as can be seen range from $\$ 44.51$ on cheap land, with a low planting cost, to $\$ 192.04$ on land worth $\$ 20.00$ an acre, and where the cost of planting is $\$ 10.00$.

TABLE I. - Investment per Acre at the End of Forty Years

\begin{tabular}{|c|c|c|c|c|c|}
\hline \multirow{2}{*}{$\begin{array}{c}\text { Land } \\
\text { valued at }\end{array}$} & & & \multicolumn{3}{|c|}{ Expenges for Planting } \\
\hline & & & 83.00 & 85.00 & 810.00 \\
\hline \multirow[t]{3}{*}{$\$ 300$} & Capital and interest & & $\$ 2881$ & $\$ 3841$ & $\$ 6241$ \\
\hline & Taxes & - & 570 & 570 & 570 \\
\hline & Total & . & $\$ 3451$ & $\$ 4411$ & $\$ 6811$ \\
\hline \multirow[t]{3}{*}{$\$ 500$} & Capital and interest & - & $\$ 3841$ & $\$ 4801$ & $\$ 7202$ \\
\hline & Taxes & . & 950 & 950 & 950 \\
\hline & Total & . $\quad$. & $\$ 4791$ & $\$ 57 \quad 51$ & $\$ 8152$ \\
\hline \multirow[t]{3}{*}{$\$ 1000$} & Capital and interest & - & $\$ 6241$ & $\$ 7202$ & $\$ 9602$ \\
\hline & Taxes & . & 1901 & 1901 & 1901 \\
\hline & Total & . & $\$ 8142$ & $\$ 9103$ & $\$ 11503$ \\
\hline \multirow[t]{3}{*}{$\$ 2000$} & Capital and interest & - & $\$ 11042$ & $\$ 12003$ & $\$ 14403$ \\
\hline & Taxes & . & 3801 & 3801 & 3801 \\
\hline & Total & . & $\$ 14843$ & $\$ 15801$ & $\$ 18201$ \\
\hline
\end{tabular}


So much for the amount expended. Now the question arises as to whether the value of the merchantable crop, at the end of 40 years, will be equal to the investment. In Table II. the returns per acre, at the end of 40 years, which may be expected from plantations of the five species considered, are given. If the values in any case seem excessive, it should be remembered that the tendency of wood prices is ever to advance, and that 40 years hence the values now given (in many instances existing at the present moment) will be too low rather than too high.

\section{TABLE II. - Returns at the End of Forty Years}

\begin{tabular}{|c|c|c|}
\hline Species & Character of the Product & Stumpage Value per Acre \\
\hline White pine & $\begin{array}{l}40,000 \text { B.M ft. @ } \$ 500 \text { per thou } \\
\text { sand. }\end{array}$ & $\$ 20000$ \\
\hline White ash & $\begin{array}{l}20,000 \text { B.M. ft. @ } \$ 1200 \text { per thou- } \\
\text { sand. }\end{array}$ & $\cdot 21000$ \\
\hline Chestnut & Ties, poles, and cordwood & 15000 \\
\hline Red oak & 40 cords of fuel wood & $1 \$ 5000$ to 8000 \\
\hline Sugar maple . & " 6 " 6 " & ${ }^{1} 5000$ to 8000 \\
\hline
\end{tabular}

1 The range in amount is due to the widely differing stumpage values of cordwood in the various parts of the State.

To the stumpage value per acre, given in Table II., must be added the value of the land (which can now be sold or used for other purposes) in order to arrive at the total returns from the plantation. Comparing the figures in Table I. with those of Table II., it is apparent that plantations of white pine and white ash will be profitable investments, yielding more than $4 \%$ compound interest for 40 years. Chestnut plantations will give similar returns, except where land is worth $\$ 20.00$ an acre and $\$ 10.00$ must be expended in planting it. But even in this case returns of practically $4 \%$ compound interest are insured.

Plantations of red oak and sugar maple are not so profitable, when cut at the age of 40 years, due largely to the fact that these trees cannot produce saw-lumber within that time. They should be allowed to grow a decade or two longer, when 
they also will be profitable. Unless with this intention, it will hardly be advisable to establish pure plantations of sugar maple and red oak as commercial investments.

On the whole, the assertion is warranted that plantations of the more valuable forest trees make excellent long-time investments. Instances are not wanting in New England, where plantations have yielded over $5 \%$ compound interest for the owners. With the advance of stumpage prices, incident on the constantly decreasing supplies of lumber, the chances are that forest plantations will yield greater returns than have here been indicated.

The disadvantage of having money tied up for so long a time is partly offset by the increased sale or pledge value which a thrifty plantation of forest trees gives to a farm or other holding. In other words, a plantation becomes a valuable asset before the timber is mature. 


\section{A P P E N D I X}

Diagram to scale of a small nursery; with a statement of its capacity for white pine, chestnut, red oak, white ash and sugar maple seedlings.

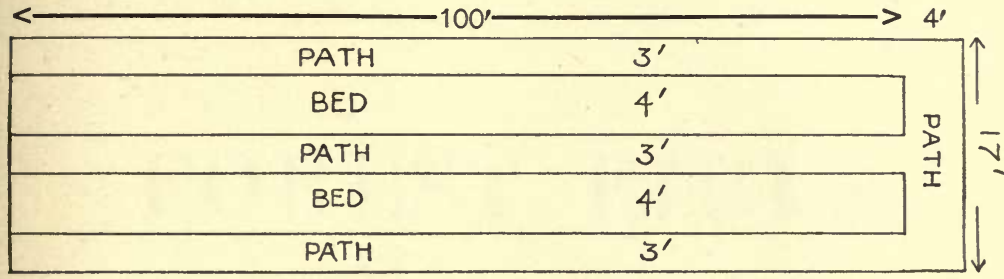

A small nursery, similar to the diagram shown above, occupying only $104 \times 17$ feet of ground, would enable the landowner who intends to plant a considerable acreage to obtain first class planting stock very cheaply. The size of the nursery, of course, should be varied to fit each owner's needs.

As outlined above, the nursery contains two beds, one to be sown each spring, after the seedlings already in it have been removed, thus providing for a continuous supply. The yield which a single bed of the size described (100 $\times 4$ feet) can furnish, will vary with the kind of seedlings it contains. Where white pine is raised, such a bed would have a capacity of 9600 seedlings, or enough to plant approximately 8 acres. To obtain this yield, the seedlings should be grown in rows 6 inches apart, with an inch between the plants as they stood in the rows. As already stated, white pine seedlings must be left in the nursery two years before they can be used for planting. So, for the first year after establishing a white pine nursery, there would be no yield; but from the second year on, a steady annual output of 9600 seedlings could be obtained by sowing seed in one bed each year.

If chestnut, red oak, white ash, or sugar maple seedlings are raised, the output of a single bed will be 4800 plants, sufficient to plant 4 acres, or just half as many as in the case of white pine. The reason for this difference is that the hardwood seedlings are grown in rows one foot apart, while the white pine as previously stated should be in rows 6 inches apart. Since seedlings of hardwood trees may be planted when one year old, a regular annual yield can be secured from the nursery beginning with the end of the first year. 



\title{
BULLETIN • • • Mglf • . . No. 5.
}

\section{Commonfwealth of a dxassacbursetts}

\author{
STATE FoREST SERvice
}

\section{FOREST FIRES}

BY

\section{ALFRED AKERMAN, M.F.}

STATE FORESTER

1904-1906

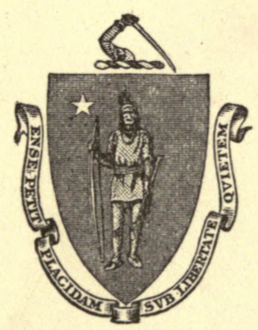

BOSTON

WRIGHT \& POTTER PRINTING CO., STATE PRINTERS

18 Post Office Square 
APPROVED BY

The State Board of Publication 


\section{MassachuseTts State Forest Service}

Frank Wm. Rane, B.AGr., M.Sc., State Forester Walter K. Fobes, Clerk 



\section{FOREST FIRES}

\section{Part I. Introduction}

Fire is the greatest enemy of the forest. Protection from fire is one of the fundamental conditions which must exist before forestry can be successfully practised.

\section{How Fire Injures the Forest}

There are many ways in which fire injures a forest. Some of these are well known and fully appreciated, but several of the most important are not usually considered when the cost of a fire is estimated.

First, a fire may kill the standing timber. This is always the case when a top or crown fire occurs. In some cases such fire-killed timber may be cut and utilized; but, as a rule, fire-killed timber does not bring a good price on the market, and only a part of the loss can be covered by its sale.

Second, a light fire may run through a stand and kill a tree only here and there. In this case the damage is not so apparent as when all the trees in the stand are killed. But a close examination of a woodlot through which a light surface fire has gone always reveals the fact that the other trees, although they are not killed, do not escape without injury. The injury may take several forms. It may be a slight scorching of the trunk, or that portion of the root system which is near the surface of the ground may be damaged. Sometimes the injured trees die later on, because, in this weakened condition, they are no longer able to withstand the attacks of insects and fungi, for which the injuries to the bark have made convenient points of entry.

Third, the vegetable part of the soil which is known as humus is consumed by a forest fire, as well as the leaves and other litter, the decomposition of which would make a future 
supply of humus. The destruction of the humus and litter affects the fertility of the soil in a marked degree. This effect is especially manifested through the relation which exists between humus and litter and soil moisture, the humus and litter tending to conserve soil moisture.

Fourth, a forest fire may result in a change in the composition of a stand of trees. Fire is often followed by an undesirable growth of poplars, birches, scrub oak, blueberry, and sumac, which growth has little or no value and is hard to get rid of.

Fifth, the young growth or reproduction is nearly always killed by a forest fire. In the long run this is probably the greatest injury of all to the forest, although it is not usually reckoned into the account at all. Suppose, for example, a woodlot is covered with a stand of white pine, ten years old; and suppose that a fire runs through the lot and that the young stand is killed, as it always is in such a case. Now, if cut and put on the market that stand would have no value; and consequently, the loss is estimated to be either nothing or next to nothing. But the time that it has taken that stand to reach its present size is lost. Suppose the owner intended to cut the crop when it should reach an age of forty years, and that the crop would have been 40,000 feet of boards worth $\$ 5.00$ on the stump, or $\$ 200.00$ an acre. Then, if $\$ 33.50$ for interest and taxes be deducted from $\$ 200.00$ and the remainder, $\$ 166.50$, be discounted for 30 years at $4 \%$ compound interest it will be seen that the loss amounts to $\$ 51.34$ per acre, or a little over one-fourth of the gross returns. Although the individual owner may not appreciate such a loss it is not a whit less real. The loss is just as real as if one-fourth of the crop should be burned in the thirty-ninth or fortieth year. And yet the item of young growth is rarely or never counted when the loss through a forest fire is being estimated.

A mere statement, therefore, of the value of the merchantable timber destroyed by a fire does not include some of the most important items of loss, such as change in composition of stand and injury to soil and young growth. 


\section{Annual Loss in Massachusetts}

As explained above, the estimated loss does not equal the real loss, and the following figures represent only the estimated loss. Moreover, the figures from 1899 to 1904 inclusive are probably not complete. They are compiled from reports on file in the office of the District Police, and there is good reason, to believe that many fires were not reported. The figures for 1885 and 1895 were taken from the State Census reports.

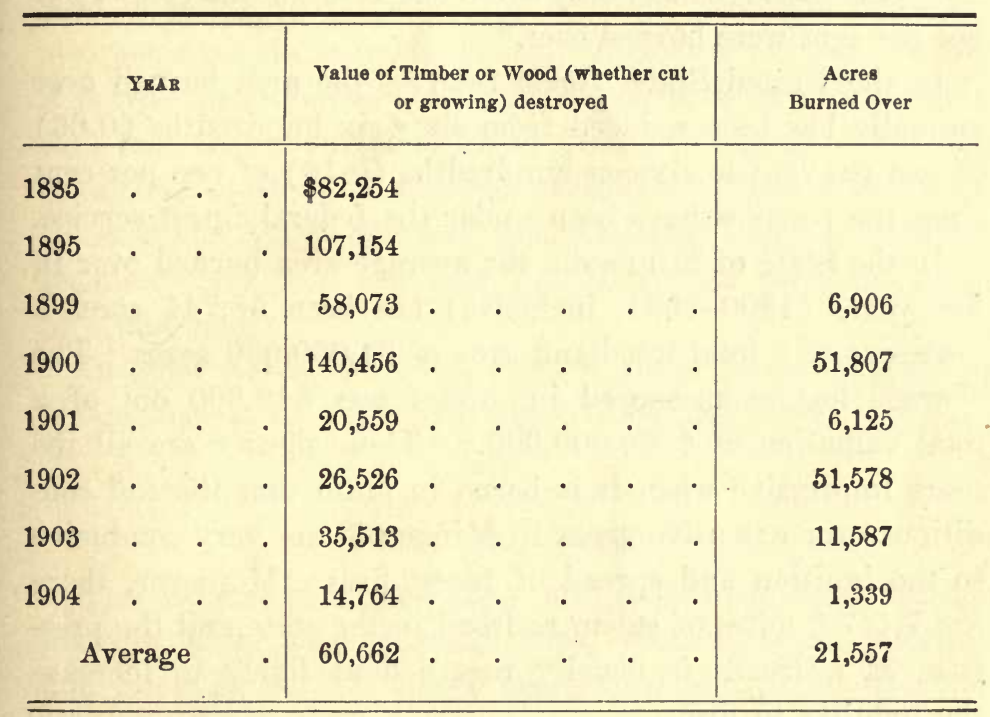

In order to get an approximation to the cost of extinguishing and preventing forest fires circular cards were sent to the town clerks and chiefs of fire departments throughout the Commonwealth. In some cases it was difficult to separate the amounts spent for forest fires from those spent for fires in buildings; and when there was doubt it was deemed best to leave out the figures altogether. The reports from 311 towns and cities show an expense of $\$ 30,880$ for the last fiscal year.

Fires occur in all parts of the Commonwealth, but the reports show that Middlesex, Norfolk, Plymouth, Bristol, and Barnstable counties are the greatest sufferers. 


\section{Can Forest Fires be Suppressed?}

That forest fires can be successfully combated is shown by the experience of foreign countries, the United States Forest Reserves, and other States.

In 7,000,000 acres in Prussia where there are extensive areas of dry, sandy, pine woods, which make the danger from fire very great, during 25 years (1868-1895) only 1,400 acres, or two one-hundredths (0.02) of one per cent, were burned over on the average per year. In Bavaria during five years (1877-1881) only seven one-thousandths $(0.007)$ of one per cent were burned over.*

In the United States forest reserves the area burned over annually has been reduced from sixty-six hundredths (0.66) of one per cent to sixteen hundredths $(0.16)$ of one per cent since the reserves have been under the federal forest service.

In the State of Minnesota the average area burned over in five years (1900-1904, inclusive) has been 58,741 acres a year, out of a total woodland area of $31,000,000$ acres. The average loss as measured in money was $\$ 49,860$ out of a total valuation of $\$ 100,000,000 . \dagger$ These figures are all the more impressive when it is borne in mind that the soil conditions over extensive areas in Minnesota are very conducive to the ignition and spread of forest fires. Moreover, there are $7,467 \ddagger$ miles of steam railroad in the state and the presence of railroads is usually regarded as likely to increase the liability to fire.

These facts show that forest fires can be suppressed and that the resultant losses can be avoided.

\section{A Comparison}

That the present system of dealing with forest fires in Massachusetts is far below the standard of efficiency is clearly shown by the following comparison:

* Fernow's “Economics of Forestry" p. 137.

$\dagger$ Minnesota Forest Fire Warden's reports, 1900-1904.

$\ddagger$ Report of Minnesota Railroad Commissioners for 1905, p. 5 . 


\section{$\overline{-}$ \\ Woodland Minnesota \\ Average arearned \\ Average per cent of total acre- age burned . . . . Average loss in money . . $\$ 49,860$ \\ Massachusett: \\ $2,688,000$ acres.* \\ 21,557 "}

Nor can Massachusetts be excused on the ground of peculiar difficulties. While it is true that Massachusetts is more densely populated and fires are more likely to occur in densely settled sections, it is also true that where the country is densely settled the woodlands are broken up by fields which tend to interrupt the spread of a forest fire; and there are also more people to put a fire out when it is started. While it is true that some sections of Massachusetts have dry, sandy soils that are conducive to forest fires, it is also true that like conditions exist in Minnesota. While it is true that Massachusetts has 2,108 $\uparrow$ miles of steam railroad and the railroads set many fires, it is also true that Minnesota has 7,467 miles of steam road.

In other words, there is a great waste of forest property in Massachusetts that can and ought to be prevented.

\section{Part II. Causes}

The eauses of forest fires are numerous, and include matches, cigar stumps, camp fires, bonfires, brush burning, and locomotives. Of these, brush fires and locomotives deserve special mention.

\section{Brush Burning}

Farmers are the chief offenders in the careless burning of brush and rubbish in the open. There is little or no excuse for the man who burns brush at such a time and in such a way as to set his own or his neighbors woods afire. Many, if not all of the fires from this cause, could be prevented by a little more care on the part of the farmers and by the adoption and strict enforcement of the law which requires

* Defebaugh's "History of the Lumber Industry of America," vol. 1. p. 284.

$\dagger$ 37th Annual Report of Mass. R. R. Commissioners, p. 6. 
a permit to set a fire in the open during the dry months. Unfortunately this law (page 17, Sec. 24), which has a referendum clause, has not been adopted by all the towns of the Commonwealth.

\section{The Railroads}

The number of fires set by the railroads is greater than from any other known cause. Fires may be set by the workmen in burning ties or rubbish along the right of way, or by coals dropped from the ash pans of locomotives, or by sparks from locomotive stacks. Fires set by workmen or by coals from ash pans are invariably the result of pure carelessness. There is no excuse for either.

The setting of fires by sparks from locomotives is a more complicated matter. The conditions under which a locomotive boiler must do its work make it impossible to prevent entirely the emission of sparks. The size of the firebox is limited to meet the conditions of locomotion. On the other hand, a great amount of coal must be consumed in order to make enough steam to draw the train. In order to burn the requisite amount of coal in a small firebox, the draft is forced by turning the exhaust from the cylinders into the front end or smoke box directly under the smoke stack. The draft thus created is so strong that small pieces of coal are often lifted from the fire and carried through the boiler into the front end. Here they are caught up by the exhaust and shot through the stack many feet into the air. If a strong wind is blowing they may be carried a considerable distance from the track before they fall. Many of these burning fragments are extinguished by contact with the exhaust steam, or are cooled in the air to a harmless cinder. But occasionally the larger and heavier ones which fall near the track are still capable of setting a fire if inflammable matter is near at hand. The insertion of a netting or spark arrester in the front end stops the largest sparks, and delays the passage of many others until they are harmless, but no spark arrester has ever been invented that will stop all sparks. If the netting is kept in repair, a fire will rarely or never be set at a distance of more than fifty feet from the center of the track. 
The problem of preventing fires from sparks resolves itself, therefore, into careful inspection and prompt repairs of spark arresters and the removal of inflammable material for a distance of fifty feet from the center of the track.

The railroads are trying to fulfil these conditions. Spark arresters are inspected at intervals and rights of way are also cleaned up at intervals. The New York, New Haven \& Hartford Railroad has in some places acquired and cleaned up the land for some seventy feet on either side of its tracks. But the great number of fires set by the roads is proof that the efforts of the railroads to prevent forest fires are only partly effective, and that there is plenty of room for improvement.

\section{Damage Claims Against the Railroads}

While the railroads are the chief sinners in setting forest fires, they are also the chief sufferers, as is shown by the figures quoted below. They represent the amounts paid in Massachusetts by the roads named in the settlement of damages from forest fires alleged to be set by locomotives.

\section{New London Northern}

for three years ending June $30,1906 \quad$. . . . . $\$ 8,33936$

Boston \& Albany

Nov. 1,1903 to Nov. 1,1904 . . . . . . . 4,69933

“ “ 1904 “ “ “ 1905 . . . . . . . . 8,45060

“ “ 1905 " July 20, 1906 . . . . . . . 7,244 62

Boston \& Maine

\section{3}

1904 1905

New York, New Haven \& Hartford

Year ending June 30, 1902 • . . . . . 13,65849

" " " 30,1903 .

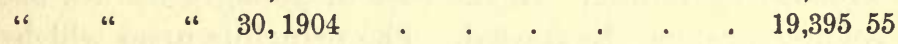

" " " $" 30,1905$. . . . . . . 26,31120

" " " 30,1906 . . . . . . 45,11296

In the light of these figures the charge commonly made that the railroads are intentionally negligent is absurd; for it is to their financial interest to restrict the number and size of claims. And yet most of the fires would not be set if 
the rights of way were kept cleared of combustible material, and if spark arresters were kept in repair. It is only right that the roads should be made to pay for their negligence, whether intentional or not.

The difficulty that an owner often has in getting a small claim adjusted has caused a great deal of ill-will toward the roads. If the damage amounts to only a few dollars, the claimant can hardly afford to hire a lawyer and take the matter into court, and he must take whatever the road chooses to give, whether it is nothing or a fair equivalent for the damage done. The aggregate of these small claims over a long stretch of road may amount to a considerable sum which the roads may or may not pay as they see fit. The roads are learning, however, that it is good policy to adjust these small claims as promptly as possible.

\section{Part III. Methods of Extinguishyent and Preventron}

There are several methods of extinguishing forest fires. The method must necessarily change with changed conditions.

In some cases the fire gets into the crowns of the trees and leaps from tree to tree. Such fires never occur except in coniferous stands and are known as crown or top fires. A crown fire is the most difficult of any to extinguish. An effective stand against it may sometimes be made along a brook or roadway, when it burns out as a crown fire and can be fought as a surface fire. If there is time an opening in the crowns may be made by felling a line of trees in front of the fire, or the opening already made by a road may be widened by felling. In the case of young growth a back or counter fire may be started. The principle upon which back firing is done is that the original fire starts a backward draft which causes the back fire to move against the direction of the original fire, and when the two meet they burn out for lack of fuel. A back fire is heroic treatment and should be employed only in extreme cases and then only by an experienced fire fighter. 
Surface fires may often be beaten out with a brush or sapling top. In some cases they can be stopped by raking back the burning material with a rake or fork. In loose, sandy soils they may be stopped by shovelling earth on the burning material. This method is employed extensively in Plymouth county. As in the case of crown fires, back firing may be resorted to in extreme cases of surface fires, but should be avoided if possible.

Portable chemical extinguishers are used to some extent in fighting forest fires. The weight of the extinguisher and the necessity of repeated charging with soda, acid, and water, have militated against their general employment.

No matter what method of fire fighting may be employed, promptness and watchfulness are essential. Many of the worst fires could be easily put out if taken in hand before they gain headway; and many will break out again if the place is not carefully watched for a day or two or until rain falls.

\section{Prevention}

In fire fighting, as in combating disease, an ounce of prevention is worth a pound of cure. The best way to put out a fire is not to let it occur.

The owner of woodlands can do much to prevent fires by running fire lines around or through the most exposed portions of his woods. These are simply strips from ten to thirty feet wide, from which the brush, deadwood and leave: have been removed. They are cheaply and easily made by raking clear a path along the margins of the line and burning the line over at a time when there is no danger of the fire getting away. For example, a line only ten feet wide along the edge of a woodlot that borders on a public road greatly lessens the danger from a fire that might result from the careless dropping of a match or cigar stump from a passing vehicle. Such lines can be prepared for less than ten dollars a mile; and they can be kept in order by burning over once or twice a year at a much smaller cost.

Notices requesting travelers and workmen to be careful in the use of fire for camping and other purposes, have been 
used with good results in some localities. They cost very little and every owner of a woodlot that is at all frequented by berry-pickers or campers should have such notices posted in conspicuous places.

The owner of woodlands can do much to prevent forest fires by a proper application of the principles of forestry. A woodlot that is kept in a thrifty condition and from which most of the dying and dead material is removed in the process of thinning is much less liable to injury from fire than one on which the dry and inflammable material is allowed to accumulate. And when plantations are made, a judicious mixture of hardwoods and conifers may prevent crown fires at a later period, as crown fires occur only in pure coniferous stands.

\section{Part IV. Fire Suppression a Public Duty}

The protection of the lives and property of its citizens is the duty of the Commonwealth. Massachusetts has recognized its duty toward woodland property by the enactment of laws designed to protect the owner against trespass, theft, and fire.

The laws intended to protect the owner against forest fires provide for the appointment of firewards by the towns. These firewards have charge of the prevention and extinguishment of forest fires in their respective towns. They report to the boards of selectmen who report in turn to the deputy chief of District Police in Boston. In cities and towns where there are regularly paid fire departments the engineers act as forest firewards. The expense of forest fire protection is borne entirely by the cities and towns.

A study of the laws (p. 16) shows that they are defective in several ways. In the first place, the system lacks a head. Nominally the Deputy Chief of District Police is at its head; but the connection is not close and as construed by the officer in charge involves only the receipt of reports and the investigation of such fires as have occurred under suspicious circumstances. In other words, the head is negative, whereas, 
in order to make the system thoroughly efficient, the head should have positive and active powers. The officer in charge should be empowered to participate in fire prevention and fire fighting on the ground, as well as to receive reports and investigate the causes of fires. This defect in the law is fundamental, and progress toward fire suppression must be halting until the defect is remedied.

The second defect in the law is closely related to the first. The towns are too small geographically to have entire charge in the matter of forest fires, which may, and often do, run from town to town. For example, a fire has been known to run over the line from one town into another, and the men who were fighting it in one town refused to cross over the line, for fear that their bills for work done in the adjoining town might not be paid.

The Commonwealth ought to have an officer with powers and duties similar to those of state forest fire warden in other states. He should have the confirmation, with right of rejection, of the fire wards who should be nominated by the towns. He should have power to establish patrols in exposed situations during the dry season and personally to direct the fight against severe fires and to order fire-fighters across a town line with the assurance that their time would be paid for.

The Commonwealth should bear a portion of the expense involved in extinguishing and preventing forest fires. In those states where the state has assumed the direction of the fire protection system and shares the expense with the towns or with the towns and counties, the results are much more satisfactory than where the towns have the whole burden of expense. Such a system while not relieving the private owners and towns of responsibility brings about an effective co-operation of all parties concerned that is not attained under the present system. 



\section{A P PENDIX}

Portions of the forest fire laws of Connecticut, Massachusetts, and Minnesota are given below for purposes of reference and comparison.

\section{CONNECTICUT}

\section{Public ACts, 1905, Chapter 238}

SEc. 1. The state forester shall be, ex officio, state forest fire State Forester warden, and shall receive no additional compensation therefor, but to be shall receive his necessary travelling and other expenses, to be paid Fire Worest in the manner provided for in section 4450 of the general statutes.

SEc. 2. Said forest fire warden shall have supervision of town Duties. fire wardens, shall instruct them in their duties, enforce the law as to fire districts in towns, issue such regulations and instructions to the town and district fire wardens as he may deem necessary for the purposes of this act, and cause violations of the laws regarding forest fires to be prosecuted.

SEc. 3. The selectmen of any town shall, upon the request of the state forest fire warden and with his concurrence appoint a town fire warden who shall act for the term of one year under the instructions of said state warden. When required by the state warden, such town fire warden shall, and any such town fire warden may establish two or more fire districts in the town for which he is appointed, and appoint a resident of such district as district fire warden; in the District wardabsence of town and district fire wardens, the first selectman may act ens. as fire warden.

SEc. 4. Town and district fire wardens shall prevent and extin- Duties of town guish forest fires in their respective towns, and enforce all statutes and district of this state now in force or that may hereafter be enacted for the protection of forest and timber land from fire, and they shall have control and direction of all persons and apparatus while engaged in extinguishing forest fires, outside the limits of cities or boroughs. Any fire warden may arrest, without warrant, any person or per- Arrest without sons taken by him in the act of violating any of the said laws for the protection of forest and timber lands, and bring such person or persons forthwith before a justice of the peace or other magistrate having jurisdiction, who shall proceed without delay to hear, try and determine the matter. During a season of drouth the town fire warden may establish a fire patrol in the town, and in case of fire in or threat- Patrol. ening any forest or woodland the town and district fire wardens shall attend forthwith, and use all necessary means to confine and extinguish such fire. The said fire wardens may destroy fences, plow land, Mreasure of or, in an emergency set back fires to check any fire. They may sum- fire. mon any male resident of the town between the ages of eighteen and May summon fifty years to assist in extinguishing fires, and may also require the assistancc. use of horses and other property needed for such purpose; any per- 
son so summoned and who is physically able who refuses or neglects to assist or to allow the use of horses, wagons or other material required, shall be liable to a penalty of not less than five dollars nor more than one hundred dollars. No action for trespass shall lie against any person crossing or working upon lands of another to extinguish fire.

Pay of warden SEC. 5. The town and district fire wardens shall receive two doland assistants. lars and fifty cents per day for time actually employed at forest fires or in the prevention thereof. The selectmen shall fix the price per hour to be paid to laborers at forest fires, employed by the fire wardens or their deputies, not exceeding twenty cents per hour, and shall give notice thereof to the town fire warden and the state forest fire warden; but if the selectmen neglect to fix said price the town fire warden may pay at the rate of twenty cents per hour for such ser-

Selectmen to audit bills.

Pald by town treasurer.

County and state each to bear one-quarter of the expense.

Special fund.

Reward for in formation.

Posting of notices. vices. The said wardens shall render to the selectmen a statement of the services rendered by them and by the men, teams, and the other apparatus employed by them as provided by this act, within one month of the date of such services, which said bill shall show in detail the amount and character of the services performed, the exact duration thereof, and all disbursements made by said wardens; said bill shall be audited, and if approved by the selectmen of the town wherein such services were rendered and expenses incurred, shall be paid on the order of said selectmen by the town treasurer. A duplicate bill, showing that the same has been audited and paid by the town, shall be filed by the town treasurer with the state forest fire warden; a copy thereof shall also be sent by said treasurer to the county commissioners of the county in which said town is situated, and the commissioners shall thereupon draw their order on the county treasurer in favor of said town for one-fourth of the amount of said bill, and another copy shall be sent to the state comptroller, who shall draw his order on the state treasurer in favor of said town for one-fourth of the amount of said bill.

SEc. 6. All moneys received from fines imposed under and by virtue of the provisions of section 1218, 1222 and 1237 of the general statutes shall be paid to the state treasurer and kept by him as a separate fund, to be paid out by him upon the requisition of the state forest fire warden, for use in connection with the prevention and suppression of forest fires, and such disbursements shall be audited by the state board of control as provided in section 4450; provided, that the state forest fire warden shall pay one-half of the amount collected as a fine to the fire warden or other person upon whose information the proceedings in which such fine was imposed and instituted, but not exceeding fifty dollars in any one case.

Note. - Sec. 7 amended Sec. 1218 of the Revised Statutes by increasing the fine of two hundred dollars to one thousand dollars.

Note. - Sec. 8, amended Sec. 1222 of the Revised Statutes by increasing the fine from fifty dollars to five hundred dollars and the imprisonment from thirty days to six months.

NotE. - Sec. 9, amended Sec. 1237 of the Revised Statutes by increasing the fine from twenty dollars to two hundred dollars.

SEc. 10. The town and district fire wardens shall post such notices, containing the state laws concerning fires, as the state fire warden may prepare, and any person who wilfully or maliciously tears down or destroys any such notice shall be fined ten dollars. 


\section{MASSACHUSETTS.}

Revised Laws, Chapter 32. Sections 1, 2 and 3 provide for the appointment of a state fire marshal and make it his duty to receive reports of fires and to investigate their causes. The office of state fire marshal was afterwards abolished and the duties of the office transferred to the Deputy Chief of District Police.

FOREST FIREWARDS.

Section 16. Selectmen shall annually, in March or April, appoint Forest fireone or more forest firewards, or, if towns having less than three hundred voters so vote, the selectmen may act as such. The engineers of fire departments in cities in which a fire department exists shall act as such.

SEction 17. In a town in which a forester has been appointed under the provisions of section fourteen of chapter fifty-three, he shall be the chief forest fireward. He shall appoint a suitable number of deputy forest firewards, one of whom, designated by him, shall be assistant chief and shall in his absence perform his duties. $\mathrm{He}$ may discharge such deputies and appoint others. He shall have sole control of the extinguishment of forest fires in his town, and he or his deputies shall act as forest firewards.

Section 18. Forest firewards shall investigate the causes of fires Duties. in woodlands and make report thereon to the mayor or selectmen. $1886,296, \S 3$. They shall post copies of this section, section sixteen and twenty of this chapter and section seven of chapter two hundred and eight in two or more public places in the city or town.

SECTION 19. If a fire occurs in woodland, two or more of the forest Back fires in firewards of the town, or of a town containing woodland which is woodlands. endangered by such fire, who are present at a place in immediate P.S. $35, \S 9$. danger of being burned over, may set back fires and take all necessary precautions to prevent the spread of the fire.

Section 20. They may, if in their judgment there is danger from Foresters may a forest fire, employ assistance or require any male person in their require ald, town between the ages of eighteen and fifty years to aid in its extinguishment or prevention, and may require the use of horses, $1897,254, \S 5$. wagons and other property adapted to that purpose, and shall keep an account of the time of all persons assisting them and a schedule of all property so used.

SECTION 21. Whoever wilfully refuses or neglects, without suf- Penalty for reficient cause, to assist, or to allow the use of his horses, wagons or fusal of aid. other property as required by the preceding section, shall, for each offence, be punished by a fine of not less than five nor more than one hundred dollars to be equally divided between the complainant and the town, and may also be imprisoned for not more than sixty days.

SECTION 22. Forest firewards shall take precautions to prevent Precautions the progress of forest fires or the improper kindling thereof, and against forest upon the discovery of such fire in their town shall immediately 1897, 254, $\S 7$. summon the necessary assistance, proceed to the fire and extinguish it. They shall cause warnings against the setting of fires and a statement of the law relating thereto, printed in large letters on cloth furnished by the selectmen at the expense of the town, to be posted in suitable places. Whoever wilfully and maliciously tears 
Compensation of foresters, etc.

$1886,296, \S 6$. $1897,254, \S 8$.

Open air fires forbidden, when.

$1897,254, \S 10$.

Expenditures authorized. $1897,254, \S \S 11$, 12.

Chief Fire Warden. down or destroys any such notice shall be punished by a fine of ten dollars.

Section 23. Payment shall be made to forest firewards, to their deputies, and to persons assisting them, and for property used under their direction at a forest fire, at a rate prescribed by the town or, in default of its action thereon, by the selectmen. No such payment shall be made until an itemized account, approved by the firewards under whose direction the work was done or assistance furnished, shall have been filed with the officer making payment.

SECTION 24. In a town which accepts the provisions of this section or has accepted the corresponding provisions of earlier laws no fire shall be set in the open air between the first day of April and the first day of October, unless by the written permission of a forest fireward. The fireward shall cause public notice to be given of the provisions of this section, and shall enforce the same. Whoever violates the provisions of this section shall be punished by a fine of not more than one hundred dollars, to be divided equally between the complainant and the town, or by imprisonment for not more than one month, or by both such fine and imprisonment.

Section 25. Money appropriated by a town under the provisions of section seventeen of chapter twenty-five, for the prevention of forest fires, and all fines received under the provisions of sections twenty-one, twenty-two and twenty-four of this chapter and section nine of chapter two hundred and eight shall be expended by the forest fireward, under the supervision of the selectmen, in trimming brush out of wood roads, in preparing and preserving suitable lines for back fires or in other ways adapted to prevent or check the spread of fire; or such town may expend any portion of such money in taking in the name of the town such woodland as the selectmen, upon the recommendation of the forester, consider expedient for the purpose of preventing forest fires. Such taking and the payment of damages therefor or for injury to property, other than by fire or back fire, shall be governed by the laws relating to the taking of land for highways.

\section{MINNESOTA.}

The laws were codified and slightly amended in 1905 . The act of 1905 is here given.

SECTron 1. The State Auditor shall be Forest Commissioner of this state and his orders shall be supreme in all matters relating to the preservation of the forests of this state and to the prevention and suppression of forest and prairie fires as hereinafter provided. The supervisors of towns, mayors of cities and presidents of village councils are hereby constituted fire wardens of their respective towns, cities and villages in the state and the Chief Fire Warden may appoint as fire wardens such other persons as he may deem necessary living in or near to unorganized territory in this state, whose districts, to be known as fire districts, he may determine.

SEc. 2. The aforesaid Forest Commissioner shall appoint a competent deputy to be known as Chief Fire Warden, who, from personal experience, is familiar with the conditions of the forest and methods by which fires may be controlled. Said Chief Fire Warden shall receive a salary of twelve hundred $(\$ 1200)$ dollars per year, to be paid out of the amount appropriated for forest preservation, and shall hold his office during the pleasure of the Forest Commissioner. - He shall represent the authority of the Forest Commissioner and it 
shall be his duty to enforce the provisions of this act throughout the state.

Sec. 3. The Chief Fire Warden shall have general charge of the Duties of fire warden force of the state and shall have authority to mass such fire warden force as may be available at any special point to suppress fires. In case the fire warden force of any locality is deemed by said Chief Fire Warden inadequate to prevent or suppress forest or prairie fires, he may appoint, temporarily, needed fire wardens whose duties and authority shall be the same as herein given to town supervisors acting as fire wardens. He shall properly divide into fire districts all unorganized territory in this state and appoint competent fire wardens therein; he shall co-operate with any police or military force of the United States Government which may be detailed to guard the national domain from fire; he shall investigate the extent of the forests in the state, together with the amounts and varieties of the wood and timber growing therein, the damages done to them from time to time by forest fires and the causes of such fires, the method used, if any, to promote the regrowth of timber, and any other important facts relating to forest interests, which may be required by the Forest Commissioner. The information so gathered, with his suggestions relative thereto, shall be included in a report to be made by him annually to the Forest Commissioner.

SEc. 4. The Forest Commissioner shall provide and officially sign Warning an abstract of the penal laws of this act, with such rules and regula- notices. tions in accord therewith as he may deem necessary, and on or before the first day of April of each year he shall forward as many copies as he considers needful to the chairman of each town board of supervisors and presidents of villages, to the forest fire wardens that he has appointed, and to all railroad companies, and to the chairman of each board of county commissioners in this state, and it shall be the duty of said fire wardens to post up such abstract as warning placards in conspicuous places in their respective districts, and it shall be the duty of the county commissioners of each county to cause the said abstract to be published in at least three issues of the official paper in their respective counties during the fire-dangerous season of each year, which shall be reckoned from the 15th of April to the 1st of November.

Sec. 5. During a dry and dangerous season, when forest and prairie fires are prevailing or are liable to break out, the Chief Fire Warden shall use such means under his command as he may deem necessary to prevent or suppress such fires, and his expenses shall be paid by the state, which expenditures in one year shall not exceed five thousand dollars, to be paid for out of the general revenue fund, upon the order of the Forest Commissioner.

SEc. 6. It shall be the duty of each fire warden to take precautions to prevent the setting of forest or prairie fires, to patrol his district in a dry season, or under the direction of the Chief Fire Warden, to employ one or more patrols, to warn against careless use of fire any person he thinks is likely to be negligent therein, and when his district is suffering or threatened with fire, to go to the place of danger to control such fires, and each forest fire warden shall have authority to call to his assistance in emergencies any able-bodied male person over eighteen years of age, and if such person refuses, without reasonable justification or excuse, to assist, or if any fire warden refuses or neglects to perform the duties assigned him in this act, such officer or person shall be deemed guilty of a misdemeanor, and shall, upon conviction thereof be punished by a fine of not more than one hundred 
Co-operation with local authorities.

State pays one-half of expense.

Careless setting of fire.
$(\$ 100)$ dollars, or imprisonment in the county jail not to exceed three (3) months.

SEC. 7. The Chief Fire Warden and the several fire wardens created or appointed under this act shall have authority to enforce the provisions of this act, and it shall be their duty to co-operate with the fire warden of any adjoining district, and in the absence of such fire wardens to direct the work of control and extinguishment of forest or prairie fires in such district, and to arrest, without warrant, every person found violating any provisions of this act, and to forthwith take the offender before a magistrate and make complaint against such person. Any fire warden who knows or has information of facts and circumstances which he believes can be established, and which if so proven would show beyond reasonable doubt that any person has caused a fire in violation of this act, shall immediately go before a justice of the peace and make complaint thereof. The chairman of boards of township supervisors, presidents of villages and fire wardens appointed by the Chief Fire Warden shall without delay inquire into the cause of each forest or prairie fire within their districts, and shall immediately report the same to the Chief Fire Warden and the methods used to control or extinguish such fires and the amount and value of property destroyed and the number of lives lost, if any, and report such other facts in regard to said fires as said Chief Fire Warden may require. During the more dangerous season of the year the Chief Fire Warden may require frequent reports from the chairman of township boards, or in unorganized towns from fire wardens appointed by the said Chief Fire Warden, as to condition of forest and prairie fires and as to what is being done to prevent and control the same. Fire wardens shall promptly comply with the instructions of the Chief Fire Warden. Where local authorities neglect to duly prosecute violations of this act, the Chief Fire Warden shall be authorized to ferret out and prosecute such violations, and his expenses therefor not exceeding one thousand ( $\$ 1000)$ dollars in any one year shall be paid out of the general revenue on approval of the State Auditor and Attorney General.

SEC. 8 [As amended by the act of the Legislature of Minnesota approved March 30,1905, and to take effect from and after its passage]. Each fire warden shall be paid for actual service at the rate of two (\$2) dollars per day, and each employee or patrol at the rate of one and fifty one hundredths $(\$ 1.50)$ dollars per day. Unless directed by the Chief Fire Warden no fire warden shall be paid for more than fifteen (15) and no employee for more than ten (10) days in any one year; but a fire warden shall receive compensation for use of team when plowing for the control of a fire. The compensation authorized by this section shall be paid out of the state treasury on duly verified vouchers approved by the Chief Fire Warden; and one-half $\left(\frac{1}{2}\right)$ the amount shall be reimbursed to the state by the county in which the expense occurred. The State Auditor shall notify the proper county auditor of the one-half $\left(\frac{1}{2}\right)$ amount that has become due from his county under the foregoing provisions and such county auditor shall immediately draw and transmit to the State Auditor a warrant on the county treasurer of his county in favor of the state for such amount.

SEc. 9. Any person who willfully, negligently or carelessly sets on fire, or causes to be set on fire, any woods, prairie or other combustible material, whether or not on his own lands, by means whereof the property of another is injured or endangered, or any person who willfully, negligently or carelessly. suffers any fire set by himself to 
damage the property of another, is guilty of a misdemeanor and shall be punished by a fine not exceeding one hundred (\$100) dollars or by imprisonment in the county jail not exceeding three (3) months. Any person who maliciously sets on fire, or causes to be set on fire, any woods, prairies or other combustible material whereby the property of another is destroyed and life is sacrificed, shall be punished with a fine of not over five hundred $(\$ 500)$ dollars, or be imprisoned in the state prison for a term of not over ten (10) years, or both such fine and imprisonment.

SEc. 10. Any person who shall kindle a fire on or dangerously near to forest or prairie land and leave it unquenched, or shall be a party thereto, and every person who shall use other than incombustible wads for firearms, or who shall carry a naked torch, fire brand or other exposed light in or dangerously near to forest land, causing risk of accidental fire, shall be punished by a fine not exceeding one hundred (\$100) dollars or imprisonment in the county jail not exceeding three (3) months.

SEc. 11. Every person who shall willfully or heedlessly deface, destroy or remove any warning placard posted under the requirements of this act shall be liable to a fine not exceeding one hundred (\$100) dollars for each such offense, or imprisonment in the county jail not exceeding three (3) months.

SEC. 12. It shall be the duty of all railroad companies operating Duty of any railroad within this state to use efficient spark arresters on all railroads. their engines and to keep their right of way to the width of fifty (50) feet on each side of the center of the main track cleared of all combustible materials and safely dispose of the same within said limits of their right of way between the fifteenth day of April and the first day of December. No railroad company shall permit its employees to leave a deposit of fire or live coals, or hot ashes, in the immediate vicinity of woodland, or lands liable to be overrun by fires, and where engineers, conductors or trainmen discover that fences or other material along the right of way or woodland adjacent to the railroad are burning or are in danger from fire, they shall report the same promptly at the next telegraph station that they may pass. In seasons of drouth railroad companies shall give particular instructions to their employees for the prevention and prompt extinguishment of fires and they shall cause warning placards furnished by the Forest Commissioner to be posted at their stations in the vicinity of forest and prairie grass lands, and where a fire occurs along the line of their road they shall concentrate such help and adopt such measures as shall be available to effectively extinguish it. Any railroad company violating the requirements of this act shall be deemed guilty of a misdemeanor and be punished by a fine not exceeding one hundred $(\$ 100)$ dollars for each such offense, and railroad employees violating the requirements of this section shall be guilty of a misdemeanor and be punished by a fine of not less than five (\$5) dollars nor more than fifty $(\$ 50)$ dollars. But this section shall not be construed to prohibit or prevent any railroad company from piling or keeping upon the right of way cross ties or other material necessary in the operation or maintenance of such railroad.

SEc. 14. Nothing in this act shall be construed as affecting any right of action for damages.

SEC. 15. Woodland territory within the terms of this act shall be construed to mean bodies of forest and brush land. 
SEc. 16. All moneys received as penalties for violating the provisions of this act shall be paid into the county treasury of the county wherein the offense occurred, to be known as the county fire fund, and used under the directions of the county board in defraying the expenses of enforcing the provisions of this act within such county.

SEC. 17. The sums mentioned in sections five (5) and seven (7) of this act, or so much thereof as shall be necessary, are hereby annually appropriated out of any money in the treasury not otherwise appropriated. 


\section{Walter Malfors}

\section{FOURTH ANNUAL REPORT OF THE}

STATE FORESTER OF MASSACHUSETTS FOR THE YEAR $1907 * * * *$

\section{FRANK WM. RANE}

STATE FORESTER

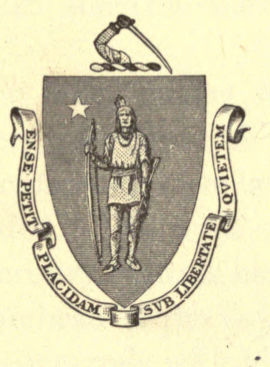

APPROVEd by the State BoARd OF Publication

BOSTON

WRIGHT \& POTTER PRINTING COMPANY, STATE PRINTERS 18 Post OfFice SQuare 
$x^{3}+x^{2}$ 


\section{Commonwealth of âtlassathrusetts.}

\section{FOURTH ANNUAL REPORT OF THE STATE FORESTER.}

To the General Court.

It is with a degree of pleasure that I offer this my first annual report, although the fourth since the establishment of the office of State Forester.

The efficiency of the office during the past year has been greatly increased in every direction. All of the lines of work previously begun by my predecessor have been carried forward, and many new features added. The work of making examinations and giving advice on forestry matters has been constantly growing, until at present the head of the department finds it almost impossible to meet the demands with his present force of assistants. The correspondence alone, we are told by the post-office authorities, has increased fully two hundred per cent during the year.

The hearty co-operation asked for upon my accepting the position of State Forester has been more than realized in the very hearty and cordial assistance rendered on every hand.

After a careful study of our forestry conditions, and definitely deciding upon what legislation was needed most, we were fortunate in being able to present some bills before the last General Court, even after the usual time had expired, due to the recommendations in Governor Guild's inaugural. These bills met with approval and were enacted.

At the forestry hearing before the committee on agriculture practically every organization in the State interested in forestry 
was present. It would be impossible to have had a more representative hearing.

The following organizations passed definite resolutions favoring the bills which afterwards were enacted: the Massachusetts State Grange, at their annual meeting at Faneuil Hall, in Boston; the Massachusetts State Board of Agriculture, at their annual winter meeting; the Eastern Shook and Wooden Box Manufacturers Association, at their annual meeting at Young's Hotel, Boston. The executive committee of the Massachusetts Forestry Association assisted in many ways, and to Mr. Henry James, Jr., the chairman, I desire to give the credit of shaping these bills in their present excellent form. The presidents of the railroads traversing our State also gave their personal support toward better forest fire regulations and laws.

\section{Forest Laws Publication.}

Upon the passage of the new forest laws the State Forester compiled the various enactments of the State forest laws, and had the same printed in a small booklet, 10,000 copies of which have been distributed quite generally throughout the State. This booklet is of convenient size for carrying in one's pocket, and also can be sent in an ordinary letter envelope, and hence is admirably adapted for dissemination and use. The double index system of reference is carried out in the publication, the paragraphs being indicated by heavier type side headings.

\section{Forest Fire Posters.}

Following the instructions in the statutes, the State Forester had the abbreviated instruction of the forest fire laws printed on a large poster, 18 by 27 inches in size, and distributed generally throughout the Commonwealth. Paper posters were printed for use indoors, while similar cloth posters were distributed for out-of-door use. 'The main heading, "Forest Fire Laws," was printed in large letters of bright red, while the remainder was printed in green ink. In compliance with the law, the railroads have placed a poster in each of their depots, and similar notices are to be found in the various post-offices of the State. The others have been posted by the town authorities. 


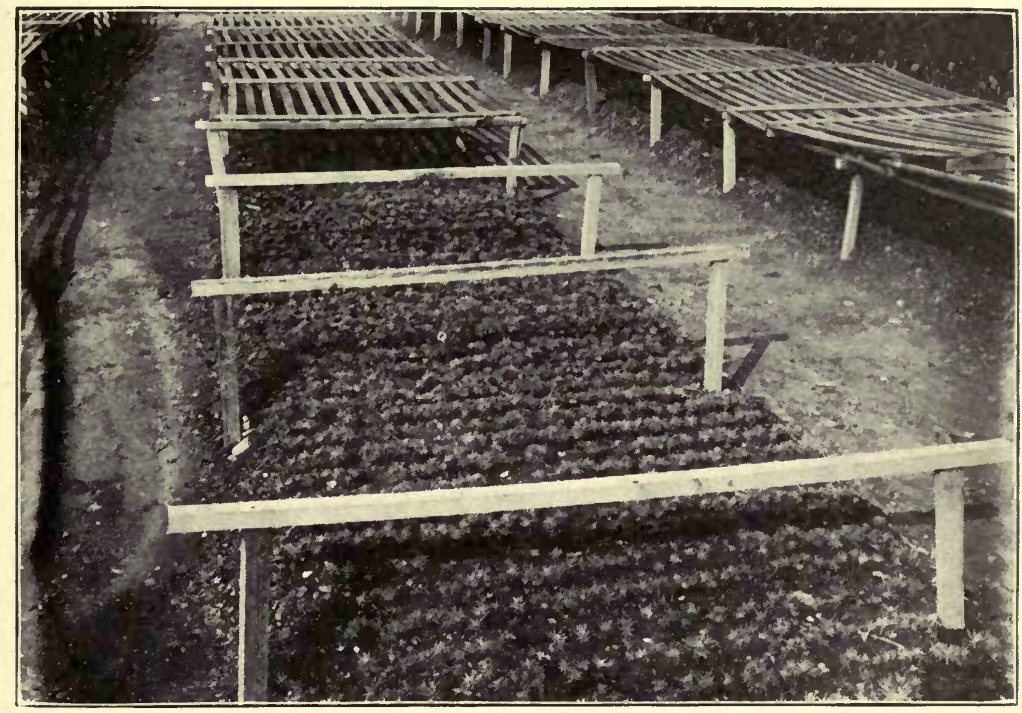

THE STATE NURSERY AT AMHERST.

White pine seedlings at the end of the first season. 



\section{The Forest Warden Law.}

Beginning with the coming spring elections in the towns, in accordance with the legislation of 1907 , the new board of selectmen is empowered to appoint a forest warden, who shall be given authority to look after the forest interests of the town.

The particular channel of usefulness whereby the recent enactments of the Legislature have made it possible for the State Forester to accomplish results is through this town forest warden system.

The appointment of the town forest warden is subject to the approval of the State Forester. His compensation is net by the individual towns, and he has the power of appointing his deputies.

The forest warden may also be called upon by the State Forester for whatever information is desired from time to time: as the correcting of his town forest acreage; amount of reforestation done during the year; number and kinds of forest fires; depredations from insect and fungous disease outbreaks, etc. For this work the warden is compensated by the State Treasurer through bills presented to and approved by the State Forester. For this work he is paid at the rate of not to exceed 35 cents an hour.

The State Forester has the privilege of calling and making arrangements for conventions of forest wardens, and paying wholly or in part their travelling expenses, the only provision being that no money shall be expended in paying the travelling expenses of any one warden to or from more than one convention in any one year; that the total expense of said convention shall not exceed $\$ 2,000$, and be held within the Commonwealth. This enactment ought to furnish to a certain extent the brief schooling each year in practical forestry to the men who most need it for accomplishing economic results in the State. The law also, it will be seen, allows the State Forester the privilege of retaining valuable wardens in the various towns when they have proven their merit.

Through this law we now have a thoroughly systematized plan of usefulness, a natural channel through which it is believed much good to our forest interests must result. When we once 
get a thoroughly organized corps of competent forest wardens, one in each of our three hundred and twenty towns, who can intelligently handle forest fires and other forestry matters of vital concern, we shall have made great progress, both from the economic and æsthetic standpoints. The small booklet, "Brief Instructions to Massachusetts Forest Wardens," discusses quite fully the duties of the forest warden. This is obtainable at the State Forester's office.

\section{Spark Arresters on Railroad Engines.}

In compliance with the law passed at the last session of the Legislature, the Railroad Commission had a conference with the various railroads of the State, and after going over the matter of establishing what was thought to be an efficient spark arrester for every engine on each road operating in the State, the commission sent out the following orders to the railroad authorities. (The following being an example of that sent to one road) :-

Petition of the New York Central and Hudson River Railroad Company, Lessee of the Boston \& Albany Railroad, for Approval of Installation and Maintenance of a Spark Arrester.

After consideration, it is -

Ordered, That the approval of the Board, under the provisions of chapter 431 of the Acts of 1907 , be hereby given to the installation and maintenance on engines of the Boston \& Albany railroad of spark arresters of the type submitted with the petition, and shown upon plan filed therewith, entitled "New York central lines; smoke box; interior arrangement; locomotive," and dated Oct. 16, 1906.

Attest: (Signed) Charles E. ManN, Clerk.

The only thing yet to be established is that some definite methods of efficient inspection be arranged, and it is believed this is a matter that the railroads will regulate satisfactorily.

\section{Public Lectures and Addresses.}

The calls for lectures on forestry by the State Forester have been many. It has been made a policy to accept invitations to address public meetings whenever it can be shown that good results are likely to follow. In accepting invitations, the request is made that an audience of at least one hundred be guaranteed, 
if possible. This request has invariably resulted in more activity on the part of the local organizations in getting out large numbers, and in more efficient and far-reaching service on the part of the State Forester. An example of this might be cited. In asking for an address on forestry by an organization whose membership was thirty-six, the acceptance was on the condition that the meeting be made public, and under the usual requirements, resulting in an audience of over five hundred. The number of lectures delivered during the year was forty-five.

\section{Lectures at the Agricultural College.}

In accordance with arrangements made with the authorities representing the trustees of the college, a course of instructions on forestry, consisting of ten lectures and exercises, was given by the State Forester to the students of the college last spring. I am frank to say that it would be impossible to work with a more satisfactory and intelligent body of students than attended this course of lectures.

A talk on forestry was also given by the State Forester before the Conference on Rural Progress, called by President Kenyon L. Butterfield in October at the Agricultural College.

\section{The National Irrigation and Forestry Congress.}

The State Forester was invited to address the above congress at Sacramento, Cal., September 2 to 7, on "State Forestry Development," and present a paper upon "The Use of Artificial Fertilizers in Forestry." This trip was also made use of in visiting some large commercial nurseries in the middle west, as well as studying general forestry methods on the Pacific coast. The congress proved a great success, and was teeming with enthusiasm and interest, peculiar to western hustle. Similar meetings in the east would be productive of great good. Massachusetts was the only New England State that was represented by a delegate, and even New York and Pennsylvania were not represented. There are many features about our New England environment and conditions that are of great advantage in forestry. One thing particularly, - we do not have the dry season to overcome; and in reforestation this one thing is greatly in our favor, to say nothing about better markets, etc. An easterner 
does well to study the comparative conditions of the east and west. If we were to keep much of our capital at home, and employ it equally as lavishly toward modern forestry or even agriculture, I believe as good or even better results could be assured.

\section{Other Lectures Outside the State.}

The State Forester has been called upon to address various other organizations of a national or State nature outside this State, and was able to give addresses on forestry before the following: the Society for the Promotion of Agricultural Science, held at Lansing, Mich., May 29; the National Horticultural Congress, held at Jamestown Exposition, September 23; and the New Hampshire State Board of Agriculture's annual winter meeting, at Whitfield, December 5. The meeting of the American Association for the Advancement of Science, which convened in New York the first of the year, was also attended.

\section{Publications.}

The publications of the office for the year are as follows:-

\begin{tabular}{|c|c|c|}
\hline & Pages. & Copies. \\
\hline "The Commonwealth of Massachusetts Forest Laws," . & 50 & 10,000 \\
\hline "Brief Instructions to Massachusetts Forest Wardens," & 12 & 5,000 \\
\hline "How and when to collect White Pine Seed," & 16 & 10,000 \\
\hline "Forestry from the Commercial Standpoint," & 16 & 5,000 \\
\hline $\begin{array}{l}\text { "The Commercial Forest Trees in Massachusetts, how you may } \\
\text { know them" (in press). } \\
\text { "Forestry in the Primary Schools" (in press), }\end{array}$ & 68 & $\begin{array}{l}5,000 \\
5,000\end{array}$ \\
\hline "Forest Laws concerning Railroads," . & 8 & 5,000 \\
\hline Total, & 220 & 45,000 \\
\hline
\end{tabular}

The Forest Nursery at Amherst.

Last spring the nursery work was reorganized and placed in the hands of R. S. Langdell of Lowell, a former student of the writer, who has greatly improved the nursery, although it has been carried on under very limited conditions. Instead of having the land allotted by the college in different places, as heretofore, it has been concentrated, and therefore more easily handled. A small, inexpensive tool and packing shed has been erected, 


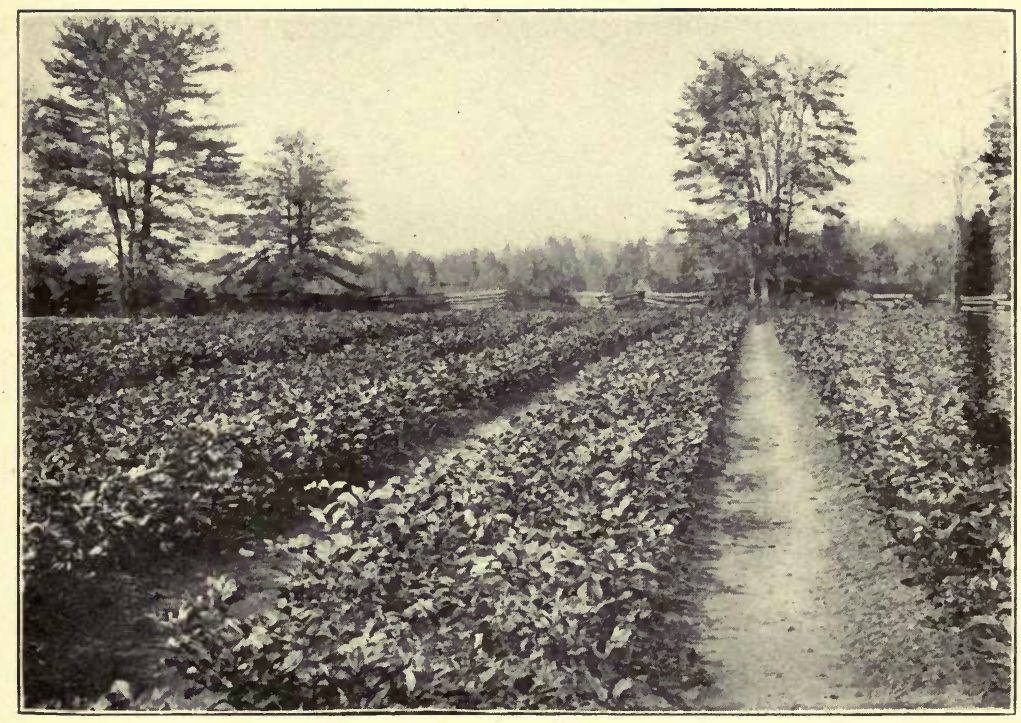

THE STATE NURSERY AT AMHERST.

Beds of white ash, ready for distribution. 

where necessary implements for nursery work are housed and seedlings packed for shipment.

\section{(a) General Forest Seedlings distributed.}

In order to awaken interest and distribute seedlings throughout the State, notices were sent to all newspapers of the State, asking them to print the following offer from the State Forester:-

Seedling Forest Trees Available. - F. W. Rane, State Forester, State House, Boston, gives notice that he can distribute, to a limited number of those who apply, 150 white pine and 150 white ash, two-year-old trees, suitable for setting out for forest purposes. Send $\$ 1$ with order. Express charges will be advanced. No orders received after April 30. One order only per person, as the object is to disseminate them quite generally. Should the supply become exhausted, the money will be returned.

Set the plants where they are to grow, 6 by 6 feet apart, as soon as they are received. Do not allow the roots to get dry.

It is hoped that this one-fourth-acre planting will create an interest in doing more planting later. It is understood that these seedlings are to be planted in Massachusetts.

In response to this offer, one hundred and twenty and onehalf orders were sent out, as indicated in the following table:-

\begin{tabular}{|c|c|c|c|}
\hline Name. & Address. & Name. & Address. \\
\hline $\begin{array}{l}\text { Azro A. Coburn, } \\
\text { Arthur M. Robinson, } \\
\text { W. W. Willard, } \\
\text { James H. Newton, } \\
\text { Robert M. Woods, } \\
\text { Mrs. Wm. L. Paddock, } \\
\text { J.S. Hubbard, : } \\
\text { W. L. White, } \\
\text { Pontoosue W o o 1 e n } \\
\text { Manufacturing Com- } \\
\text { pany, } \\
\text { James Griffin, } \\
\text { Charles W. Power, } \\
\text { Geo. H. Goodbeer, } \\
\text { Wm. B. Kimball, } \\
\text { John H. Holder,. } \\
\text { H. G. Zilliacus, } \\
\text { Roy L. Eaton, } \\
\text { Silas W. Hutchinson, } \\
\text { Waldo C. York, } \\
\text { Thomas C. Esty, } \\
\text { C. H. Waymouth, } \\
\text { Albert F. White, } \\
\text { Miss Helen Holmes, } \\
\text { Willis F. Austin, } \\
\text { W. F. Whitney, } \\
\text { Warren F. Bemis, } \\
\text { Priest Bros., }\end{array}$ & $\begin{array}{l}\text { Holyoke. } \\
\text { Pittsfield. } \\
\text { Springfield. } \\
\text { Holyoke. } \\
\text { Dalton. } \\
\text { Fiskdale. } \\
\text { Phillipston. } \\
\text { Pittsfield. } \\
\text { South Hadley. } \\
\text { Pittsfield. } \\
\text { Fitchburg. } \\
\text { Enfield. } \\
\text { Hudson. } \\
\text { Fitchburg. } \\
\text { Salisbury. } \\
\text { Fitchburg. } \\
\text { Marstons Mills. } \\
\text { Amherst. } \\
\text { Fitchburg. } \\
\text { East Freetown. } \\
\text { Kingston. } \\
\text { Amesbury. } \\
\text { South Ashburn- } \\
\text { ham. } \\
\text { Hubbardston. } \\
\text { Littleton. }\end{array}$ & $\begin{array}{l}\text { Lewis Damon, } \\
\text { James L. Miller, } \\
\text { W. L. Harris, } \\
\text { Horace T. Fogg, } \\
\text { John W. Waters, } \\
\text { Arthur P. Rugg, } \\
\text { P. W. McCellan,* } \\
\text { Eben S. Fuller, } \\
\text { J. W. Van Huyek, } \\
\text { A. J. Wellington, } \\
\text { E. F. Powers, } \\
\text { Lester R. Maynard, } \\
\text { L. B. Ramsdell, } \\
\text { W. A. Munson, } \\
\text { Claude J. Mathieu, } \\
\text { Joseph Smith, } \\
\text { David H. Tillson, } \\
\text { Edward F. White, } \\
\text { Charles L. Johnson, } \\
\text { R. L. Bowman, } \\
\text { J. M. Perkins, } \\
\text { Henry F. Whitney, } \\
\text { Myron A. Richardson, } \\
\text { Edwin Warren, } \\
\text { Thaxter Scott \& Son, } \\
\text { Geo. E. Cogswell, } \\
\text { J. F. Rice, Partridge, } \\
\text { Walter F. Part } \\
\text { J. Henry Gleason, }\end{array}$ & $\begin{array}{l}\text { Ashby. } \\
\text { West Lynn. } \\
\text { Deerfield. } \\
\text { Norwell. } \\
\text { Fitchburg. } \\
\text { Sterling. } \\
\text { Haverhill. } \\
\text { Clinton. } \\
\text { Iee. } \\
\text { Ashburnham. } \\
\text { Leominster. } \\
\text { South Berlin. } \\
\text { Gardner. } \\
\text { Huntington. } \\
\text { West Bovlston } \\
\text { Unionville. } \\
\text { Amherst. } \\
\text { Holyoke. } \\
\text { Southborough. } \\
\text { Middleborough. } \\
\text { Hudson. } \\
\text { Lowell. } \\
\text { West Brookfield } \\
\text { Spencer. } \\
\text { Hawley. } \\
\text { Cushman. } \\
\text { Barre. } \\
\text { West Upton. } \\
\text { Marlborougn. }\end{array}$ \\
\hline
\end{tabular}




\begin{tabular}{|c|c|c|c|c|}
\hline Name. & Address. & NAME. & & AdDREss. \\
\hline $\begin{array}{l}\text { Chas. M. Phelps, } \\
\text { Marcus M. Multer, } \\
\text { Thos. H. Skinner, } \\
\text { E. H. Alderman, } \\
\text { Mrs. Adolph Miller, } \\
\text { Mrs. Mary A. Butterick } \\
\text { G. L. Twitchell, : } \\
\text { C. L. Fairbanks, } \\
\text { E. W. Howe, } \\
\text { Chas. F. Allen, } \\
\text { Frank Sprague, } \\
\text { P. C. Bronson, } \\
\text { F. H. Holden, } \\
\text { D. S. Freeman, } \\
\text { John H. Daniels, } \\
\text { C. H. Ball, } \\
\text { R. F. Walsh, } \\
\text { Wm. Haskett, } \\
\text { F. W. Whitney, } \\
\text { O. E. Bradway, } \\
\text { Julia F. Darling, } \\
\text { Wm. Hale, } \\
\text { H. J. Franklin, } \\
\text { Henry M. Allen, } \\
\text { Lot Phillips \& Co., } \\
\text { J. W. Howes, } \\
\text { E. C. Wright, } \\
\text { C. E. Norton, } \\
\text { J. A. Monahan, } \\
\text { C. H. Johnson, } \\
\text { Edwin A. Start, } \\
\text { F. H. Foster, } \\
\text { H. Gertrude Hale, } \\
\text { : }\end{array}$ & $\begin{array}{l}\text { Blandford. } \\
\text { Marlborough. } \\
\text { Princeton. } \\
\text { Chester. } \\
\text { West Springfield. } \\
\text { Sterling. } \\
\text { Brookfield. } \\
\text { Southborough. } \\
\text { Concord. } \\
\text { Rowley. } \\
\text { Still River. } \\
\text { Ashfield. } \\
\text { Plainfield. } \\
\text { Millington. } \\
\text { Fitchburg. } \\
\text { East Windsor. } \\
\text { Easthampton. } \\
\text { South Athol. } \\
\text { South Athol. } \\
\text { Monson. } \\
\text { Milford. } \\
\text { Newburyport. } \\
\text { Wareham. } \\
\text { Chilmark. } \\
\text { West Hanover. } \\
\text { South Fall. } \\
\text { Campello. } \\
\text { Cambridge. } \\
\text { Fiskdale. } \\
\text { Easthampton. } \\
\text { Billerica. } \\
\text { Andover. } \\
\text { Templeton. }\end{array}$ & $\begin{array}{l}\text { Walter White, } \\
\text { C. R. Stewart, } \\
\text { Wm. B. Hale, } \\
\text { Seth P. N. Hall, } \\
\text { A. B. Terry, } \\
\text { A. S. Lodge, } \\
\text { L. E. Parminter, } \\
\text { L. W. Buffington, } \\
\text { L. W. Morgan, } \\
\text { B. F. Collins, } \\
\text { L. M. Thomas, } \\
\text { Benjamin D. Hyde, } \\
\text { W. A. Graves, } \\
\text { R. R. Ranney, } \\
\text { W. H. Carter, } \\
\text { Miss Sarah Fuller, } \\
\text { Ella C. Jordan, . } \\
\text { Geo. B. Haskell, } \\
\text { Charles A. Stone,* } \\
\text { Fred A. Hannaford, } \\
\text { L. Cora Brown, } \\
\text { Thomas R. B. Dole, } \\
\text { A. M. Bridgman, } \\
\text { Arthur H. Wellman, } \\
\text { A. P. White, } \\
\text { C. H. Copeland, } \\
\text { Geo. W. Burroughs, } \\
\text { L. L. Lewis, } \\
\text { F. W. Peters, }\end{array}$ & $\begin{array}{l}\dot{0} \\
\dot{0} \\
\dot{5} \\
\dot{5} \\
\dot{5}\end{array}$ & $\begin{array}{l}\text { Templeton. } \\
\text { Templeton. } \\
\text { Templeton. } \\
\text { Williamsville. } \\
\text { Williamsville. } \\
\text { Williamsville. } \\
\text { Williamsville. } \\
\text { Williamsville. } \\
\text { Williamsville. } \\
\text { Williamsville. } \\
\text { Templeton. } \\
\text { North Amherst. } \\
\text { Greenfield. } \\
\text { Ashfield. } \\
\text { Andover. } \\
\text { N e w t o n Lower } \\
\text { Falls. } \\
\text { Newton. L o w e r } \\
\text { Falls. } \\
\text { Rochester. } \\
\text { Plymouth. } \\
\text { South Lancaster. } \\
\text { Concord. } \\
\text { Ayer. } \\
\text { State House, } \\
\text { Boston. } \\
\text { Topsfield. } \\
\text { Salem. } \\
\text { Scituate. } \\
\text { Acton. } \\
\text { Ashland. } \\
\text { Bolton. }\end{array}$ \\
\hline
\end{tabular}

* Two orders.

\section{(b) Distribution of Forest Tree Seeds and Seedlings to Schools.}

Thinking our public schools might be interested in having some seeds and seedlings for educational purposes, the following letter was addressed to each superintendent in the State:-

\section{To School Superintendents.}

In connection with the State forest service we have a forest nursery, and it has occurred to me that there are schools that would derive a great deal of knowledge and economic benefit from having a small collection of forest tree seedlings growing in the school grounds or in the school gardens where they are already established.

Forestry is a subject worthy of promotion, and the simple A B C of forestry can well be begun with our school children. Trees have much of interest in them at any time of the year, and hence can be studied at any season. There is wide interest at present in school gardening; if to it we add some forest nursery work, making it a year-round affair and a perennial rather than for a short season each year, I am sure it will be a happy improvement.

Make it a plan to have the children collect tree seeds when they are ripe; then plant and care for the seedlings, ultimately transplanting them upon our many thousand acres of waste land in all sections of our Commonwealth. Some seeds, like the acorn and chestnut, may be planted directly where they are to grow. 
In order to assist any schools in a beginning, I am going to offer to a limited extent, in so far as our seedlings hold out, and we can spare the time to do the work, - first come, first served, - a collection of seedlings and seed as follows:-

12 white pine seedlings, two years old. 24 white ash seedlings, two years old.

12 red spruce seedlings, two years old.

5 beech seedlings. $\frac{1}{2}$ ounce of white pine seed (900 seed). 12 chestnut seed.

25 acorn seed.

50 white ash seed.

Bulletin No. 4 of this office, giving instructions for handling and care of the nursery, will be sent with each order.

The only expense to the school requesting this list will be the estimated actual expense in digging, packing, etc., $\$ 1$ for each collection. The express charges will be advanced. Only one collection is offered a school. The $\$ 1$ should accompany the order. Should we be unable to send the collection, the money will be returned. No orders should be sent in to reach the office later than May 1.

It is hoped that in this small beginning we may foster in the young, our coming generation, not only a fundamental economic recognition of forestry, but return to Massachusetts and New England the natural beauty we all so much would love to see.

$$
\begin{gathered}
\text { F. W. RANE, } \\
\text { Yours very sincerely, } \\
\text { State House, Boston, Mass. }
\end{gathered}
$$

In response to this offer forty-seven orders were received, and

\begin{tabular}{|c|c|c|c|}
\hline NAME. & ADDREss. & Name. & AdDress. \\
\hline $\begin{array}{l}\text { C. H. Morse, } \\
\text { Mary L. Lincoln, } \\
\text { H. E. Richardson, } \\
\text { Amelia R. Amos, } \\
\text { A. L. Hardy, } \\
\text { J. W. Waters, } \\
\text { Prof. C. M. Weed, } \\
\text { John G. Thompson, : } \\
\text { W. S. Bagg, } \\
\text { S. D. Brooks, : } \\
\text { C. S. Lyman, } \\
\text { Monatiquot school, : } \\
\text { Penniman school, } \\
\text { Noah Torrey school, } \\
\text { W. L. Coggins, } \\
\text { W. E. Gushee.: } \\
\text { E. F. P. Perrin, } \\
\text { L. M. Moody, : } \\
\text { S. W. Ferguson, } \\
\text { Miss R. O. Kendall, : } \\
\text { Miss Adah L. Harvey, }\end{array}$ & $\begin{array}{l}\text { Medford. } \\
\text { Lancaster. } \\
\text { Greenfield. } \\
\text { Nort h Attlebor- } \\
\text { ough. } \\
\text { Amherst (2 orders). } \\
\text { Fitchburg. } \\
\text { Lowell. } \\
\text { Fitchburg. } \\
\text { Springfield. } \\
\text { Brighton. } \\
\text { Hudson. } \\
\text { Braintree. } \\
\text { Braintree. } \\
\text { South Braintree. } \\
\text { Rockland (8 orders). } \\
\text { Ludlow (3 orders). } \\
\text { Grammar s c h oo l, } \\
\text { West Barnstable. } \\
\text { High school, Hy- } \\
\text { annis. } \\
\text { Osterville. } \\
\text { Pittsfield. } \\
\text { Northfield grammar } \\
\text { school. }\end{array}$ & $\begin{array}{l}\text { Frank A. Andrews, : } \\
\text { Mary L. Potter, } \\
\text { Florence Marshall, : } \\
\text { John I. Rackcliffe, : } \\
\text { Edward Warren, } \\
\text { Benj. D. May, : } \\
\text { Jessie P. Leary, } \\
\text { Jennie C. Foskett, : } \\
\text { Wm. H. Martin, : } \\
\text { Lincoln Owen, } \\
\text { M. S. Donaldson, : } \\
\text { M. L. Brown, : } \\
\text { F. A. Morse, } \\
\text { Helen F. Batchelder, } \\
\text { E. H. Russell, . } \\
\text { Nellie L.Bailey, }\end{array}$ & $\begin{array}{l}\text { Greendale s c h o ol, } \\
\text { Worcester. } \\
\text { Lawrence. } \\
\text { Tolland. } \\
\text { Campello. } \\
\text { Spencer. } \\
\text { Nantucket. } \\
\text { Salem. } \\
\text { Charlton. } \\
\text { Comins school, Rox- } \\
\text { bury C ros ing, } \\
\text { Boston. } \\
\text { Rice school, Boston. } \\
\text { Brockton. } \\
\text { Rhode Island Nor- } \\
\text { mal School, Prov- } \\
\text { idence, R. I. } \\
\text { R. G. Shaw school, } \\
\text { Boston. } \\
\text { Bridgewater. } \\
\text { St a te Nor m a l } \\
\text { School, Worcester. } \\
\text { S c h o i S t r e et } \\
\text { school, Haverhill. }\end{array}$ \\
\hline
\end{tabular}
sent out as indicated in the following table:-

Fifteen thousand two-year-old white pine seedlings were purchased from the New York State Forester and several thousand 
from other sources, which were used in filling the above orders.

Each person for whom a forest working plan or assistance in forestry has been given, in so far as there were records in the office, was consulted, that he might be assisted in procuring seedlings at reasonable rates. The office charged in each instance simply enough to cover the expense of first cost to the State. Where many small lots, as to schools and farmers, were sent, the expense of packing for shipment has been proportionally higher than were we shipping in larger quantities.

\section{(c) Other Seedlings distributed.}

Besides the above, the following seedlings were also distributed from the nursery:-

C. F. King, Taunton, 5,000 white ash, Mr. Paine, State House, 250 beech, 500 white ash, Mr. Paine, State House, 1 pound white pine seed, F. A. Smith, Taunton, 1,000 white ash, Theodore F. Borst, South Framingham, 6,000 white ash, W. G. Nickerson, Dedham, 3,000 white ash, Alfred S. Hayes, Ashland, 4,000 white ash, Lyman E. Ware, Norfolk, 1,000 white ash and 50 white pine, Edward Sturgis, Andover, 500 white pine, . C. N. Field, Foxborough, 100 white ash,
$\$ 1500$

225

400

300

1800

900

1200

325

150

35

Total,

Nursery Stock on Hand, Fall, $190 \%$.

White ash transplants,

White pine, one year old,

White pine, two years old,

Norway spruce, one year old, .

Norway spruce, two years old, .

Catalpa, one year old,

Chestnut, one year old,

Sycamore,

40,000

200,000

15,000

25,000

2,000

3,500

Maple, red,

Maple, rock, . $\quad$. $\quad$. $\quad$. $\quad$. $\quad$. $\quad$. 100

White pine, two years old, purchased from nurserymen, . 250,000 


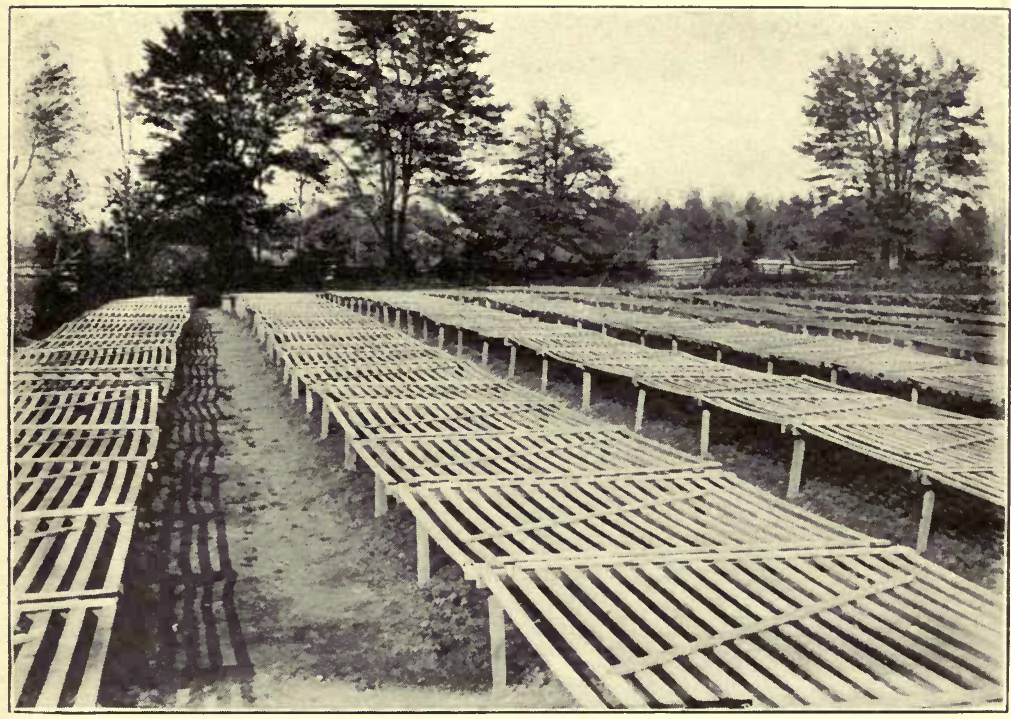

PORTION OF THE STATE NURSERY AT AMHERST.

Showing the screen protection given evergreen seedlings. 

White pine, .

Chestnut,

Box elder,

Locust,

Horse chestnut,

Norway spruce,

Pitch pine, .

Austrian pine,

Tulip tree,

Maple,
65 pounds.

1 bushel.

1 bushel.

small amount.

"،

$66 \cdot 66$

$66 \quad 66$

66

66

$66 \quad 66$

Fifty pounds of white pine seed have also been purchased for spring distribution.

The trustees of the Agricultural College have voted additional land for next spring's use in enlarging the present area. It is believed we can well afford to do even more in growing and distributing various tree seedlings at cost. When the time comes that commercial growers are prepared to furnish them at lower rates, the States' policy will undoubtedly be to do less.

\section{Forestry Exhibits.}

Two forestry exhibits have been made by the State Forester during the year, one at the Sportsmans' Show, held at the Mechanics building in Boston last spring, and the other at the annual winter meeting of the State Board of Agriculture, held at Horticultural Hall, Boston, December 3, 4 and 5. 'The exhibit consisted in showing different kinds of forest seeds and seedlings of various ages. The seedlings and transplants were displayed in the ordinary seed-bed conditions, and also suspended in glass jars, so the whole root system could be shown. Photographs, forest maps, wood sections, forest implements, charts, forest fire posters and a full set of the publications of the office were also shown. A number of names of persons interested were secured, and much assistance given by way of explanation of the material at hand. After making the last exhibition the material was moved into a room adjoining this office in the State House, where it is being used for demonstration purposes. 
Co-operation with the United States Forest Service.

The State Forester wishes here to acknowledge the hearty co-operation that Mr. Gifford Pinchot and his able assistants have rendered whenever called upon. When requests have gone in to the United States Forest Service for assistance on examinations, lectures, etc., from Massachusetts, they have been referred to this office by the Forest Service, and we have gladly co-operated in the work.

Examination of Woodlands and Practical Assistance GIVEN OWNERS.

This work has been one of the strong features of the office from the first, and nothing has been left unturned to make the work effective and helpful to as many applicants as we were able to assist during the year.

All the work heretofore done by my predecessor in office was carefully gone over, and in as many cases as possible the actual field examined. In every case of which there is a record in the office, the owner was either seen personally or addressed, in order to know just how effective the assistance has been. Not only was this system carried out with the examinations and assistance of this office, but the United States Forest Service heartily co-operated in sending a complete set of the working plans and names of persons from Massachusetts who had been assisted not only before this office was established but up to the present. This, therefore, gives us the data at hand of practically all of the examinations and assistance given in the State.

After completing the above list, each person receiving assistance was requested to furnish an up-to-date report of just what he had actually accomplished. The information thus received has been very valuable in guiding the work this year. Unfortunately, there were many instances where the assistance has resulted in nothing but an expense to the State, in that there seems to be little likelihood of its ever being made use of. This is particularly true of some of the most elaborate and expensive work this office has done. After trying to renew an interest in carrying out the original plan of these earlier applicants, the attention of the office was turned to the assistance of new applicants.

There were found to be 86 citizens on record as having had 
woodland examinations. Of this number, 41 replies were received, 23 of which were carrying out the suggestions offered, and 8 wished further assistance. Upon studying the problem, it was found that to make the work effective something more than just a working plan and the giving of written advice are necessary to accomplish the success desired.

Mr. J. J. Dearborn of the Harvard Forestry School, and a young man of much practical forestry experience, was put in charge of this work. We followed out the policy of first meeting the owner upon his property, and of going over the proposed woodland proposition and getting as near as possible his needs and purposes. We then interested him in so far as practicable to determine what should and could be done, provided further plans and assistance were given. We have made 37 new examinations during the past year. Of this number, 33 are following out or contemplating the advice given. By contemplating is meant that they have already placed orders for seedlings, or shown definite indications of doing something either this winter or next spring.

Markings for thinnings have been made over different tracts, amounting in area to some 50 to 100 acres. In almost every case where a thinning was advised, enough was actually done to convey, as an example, the right idea to the owner.

The actual superintendence of the thinning out of one tract has been performed by the office, in order to demonstrate its practicability and secure definite data which is to be used in illustrating methods and results.

The largest tract that the office has undertaken is one of 1,600 acres, in the Berkshires. The field work and data have been secured for this tract, but the making of the map and report of office work end is still in progress. As a result of our assistance, the owner of this tract has employed as a permanent forester a graduate of the Harvard Forestry School of last year. The other tracts examined have been much smaller in area, although a number are of fair proportions, as Massachusetts woodlands run.

We have now several new applications on hand for examinations, one application for a working plan, and some requests for markings for thinnings.

In order to keep in touch with the cost of operations and 
stumpage values, circular letters and schedules to be filled out have been sent to the lumbermen and dealers in different sections of the State.

\section{Technological Work.}

During the past summer measurements were made by this office looking towards the construction of a yield table for white pine. A yield table is one which shows the amount of wood per acre that one can expect to obtain from pure even-aged stands of pine at different ages and for different localities. It is especially valuable to predict the yield of planted stands, since such stands are most likely to fulfill the conditions of the table. To make such a table it is necessary to select a large number of sample. plots, one-quarter or one-eighth acre in size, taking care that the plots represent a great variety of ages, and as broad a range of locality and growing conditions as one can expect to find in a State of the size of Massachusetts. All the trees on the sample plots are measured for diameter and height, and the amount of lumber in each obtained from volume tables.

This work was in charge of Mr. H. O. Cook of this office, who had the assistance of Messrs. W. G. Howard and R. F. Weston of the Harvard Forest School, and Mr. R. C. Hall of the Yale Forest School. During two months, July and August, they measured one hundred and seventy-eight plots, in fifty-two towns. The accompanying map shows the towns and gives a clue to the number of plots measured in each. Other towns were visited, but as no plots were measured in them, no record of them was kept.

The travelling was largely done on foot; wood-using factories were visited, fire wards interviewed, and in various ways a great deal of general but valuable information on the forest growth, lumber prices, and on other subjects of interest to foresters was picked up and made note of.

The accompanying map is not alone useful in connection with the yield table work, but it gives some clue to the pine distribution in the State. The sections visited were naturally the leading pine-growing regions, and within these regions the amounts in the different towns are roughly proportional to the number of sample plots measured in those towns. The region of greatest production is in the northern part of Worcester County, together 


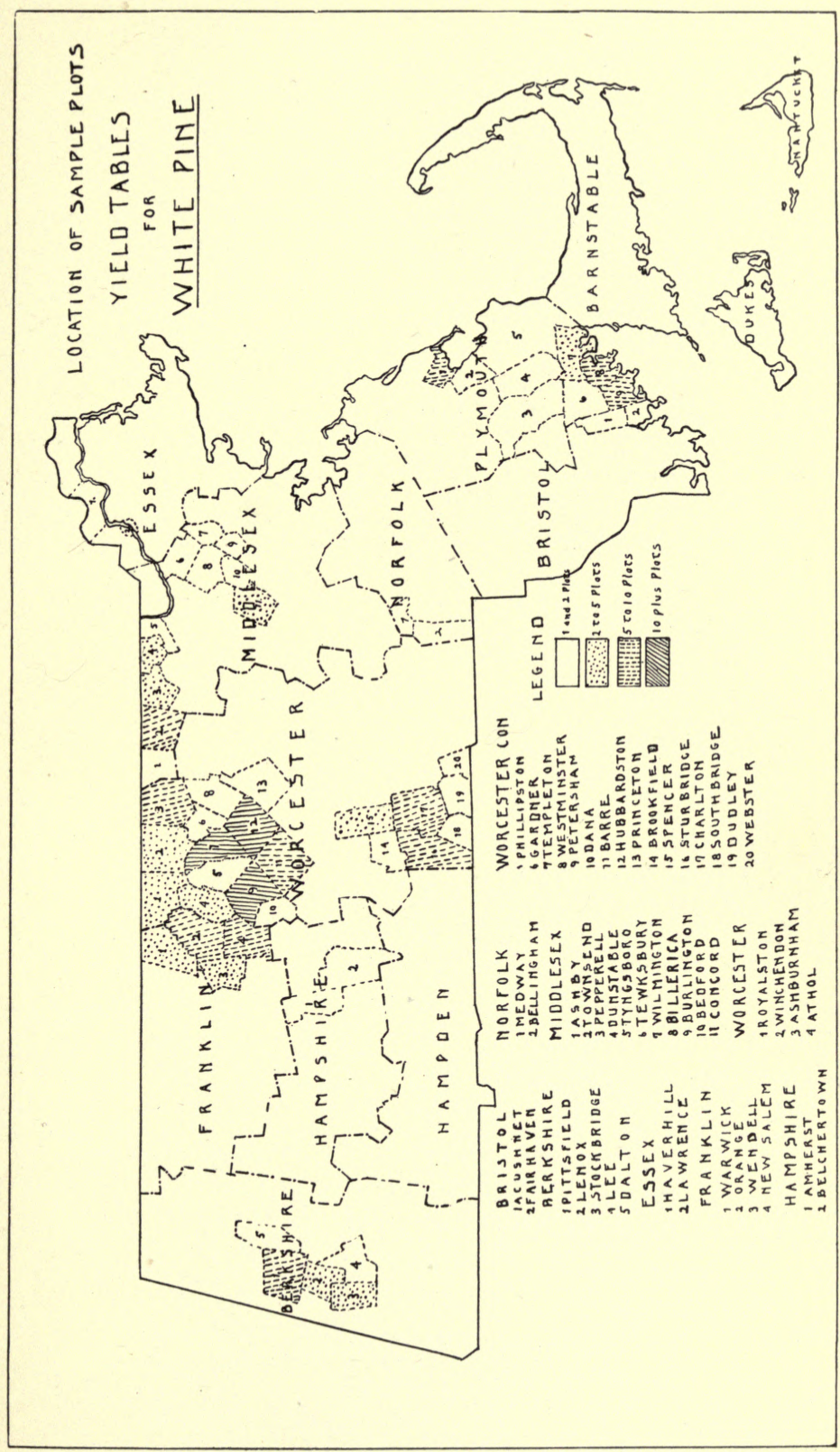



with adjoining portions of Franklin and Middlesex counties. Petersham, where twenty-three sample plots were measured, is the banner town of this region and of the State.

The growth of individual pine trees, as well as the growth of acre stands has been studied by making what are known to foresters as stem analyses on more than two hundred and fifty trees. Where cutting is going on, trees are selected and the separate logs are measured for length, diameter and the growth for ten-year periods, as shown by the annual rings. The growth of the various logs together with the stump and the top when put together make up the growth of the entire tree. The individual trees are then assigned to certain types of growth, and tables constructed which will show the rate of growth of pine under varying conditions, and its rate of growth at different ages.

The yield tables, the growth tables and other information concerning the white pine as it grows in this State will soon be published in bulletin form.

Yield per Acre from thinning Pure, fully stocked White Pine.

\begin{tabular}{|c|c|c|c|c|c|c|c|c|}
\hline \multirow{2}{*}{$\begin{array}{c}\text { AGE } \\
\text { (YEARS). }\end{array}$} & \multicolumn{4}{|c|}{$\begin{array}{l}\text { Trees Five Inches or More } \\
\text { in Diameter. }\end{array}$} & \multicolumn{4}{|c|}{ All Trees. } \\
\hline & $\begin{array}{l}\text { Board } \\
\text { Feet. }\end{array}$ & $\begin{array}{c}\text { Stump- } \\
\text { age at \$6 } \\
\text { per M. }\end{array}$ & $\begin{array}{l}\text { Value } \\
\text { at } \$ 16 \\
\text { per } M .\end{array}$ & $\begin{array}{l}\text { Cubic } \\
\text { Feet. }\end{array}$ & Cords. & $\begin{array}{c}\text { Value } \\
\text { at } \$ 5 \text { per } \\
\text { Cord. }\end{array}$ & $\begin{array}{c}\text { Stump- } \\
\text { age at \$4 } \\
\text { per Cord. }\end{array}$ & $\begin{array}{l}\text { Cubic } \\
\text { Feet. }\end{array}$ \\
\hline 25 & 1,400 & $\$ 840$ & $\$ 2240$ & 280 & 11.0 & $\$ 5500$ & $\$ 4400$ & 880 \\
\hline 30 & 3,700 & 2220 & 5920 & 720 & 12.0 & 6000 & 4800 & 1,040 \\
\hline 35 , & 4,950 & 2970 & 7920 & 850 & 12.3 & 6150 & 4920 & 1.090 \\
\hline 40 & 6,000 & 3600 & 9600 & 1,030 & 12.8 & 6400 & 5120 & 1,150 \\
\hline 45 & 6,800 & 4080 & 10880 & 1,140 & 13.0 & 6500 & 5200 & 1,190 \\
\hline 50. & 7,400 & $44 \quad 40$ & 11840 & 1,240 & 13.4 & 6700 & 5360 & 1,240 \\
\hline 55. & 7,900 & 4940 & 12640 & 1,310 & 14.0 & 7000 & 5600 & 1,310 \\
\hline
\end{tabular}

The above table shows the yield to be obtained by thinning white pine stands of different ages in cases where the stand is pure, containing no other trees but white pine, and fully stocked, - that is, without pronounced holes or blanks.

The table is divided into two parts, one for trees five inches or more in breast-high diameter, the volumes of which are indicated in broad measure. The corresponding money values are given,in the second column the stumpage value at $\$ 6$ per thousand, and 
in the third column the value of the lumber at $\$ 16$ per thousand. The stumpage value is purposely put low, because in general the material taken out in thinnings is not of the highest quality, and is more expensive to get out than if the stand is cut clean.

In the second part trees of all sizes are included, and their volume is given in cords. Stumpage is reckoned at the rate of $\$ 4$ a cord. The value $(\$ 5)$ used in the second column is the price usually obtained by owners who cut and haul their own wood to the mill in small lots. If $\$ 1$ is allowed for the labor of chopping and $\$ 1$ for the hauling, it will be seen that by this method the farmer gets a stumpage rate of only $\$ 3$, which is less than the common rate. This method of operating, however, has certain advantages in making thinnings: first, because any quantity of material, no matter how small, can be cut and sold; second, the cutting, when done by the owner, is sure to be done carefully, and this is important in making thinnings; third, if the work is done during the winter, when the farmer and his team have little to do, the entire $\$ 5$ can be regarded as clear profit.

\section{Forest Map.}

Two years ago the State Forester started the construction of a forest map of the State, through the agency of the census department. Agents of this department were provided with maps of all the towns in the State, visited the assessors of each town, and from their collective knowledge had them sketch on the maps the forest area, with notes on the kind of growth thereon. This method is at best rather a crude form of map making, and the data inaccurate, even though many of the maps have been corrected by members of this office. Until a more costly and better map can be made, however, it provides our best means for getting at the forest growth of the State and its area. The forest area so taken has been measured by this office, and the results of these measurements are given in the adjoined list.

The growth is divided into three main types: the pine type, woodland containing over seventy-five per cent white pine; woodland consisting wholly of hard woods; and a mixed type of hard woods, in which are scattering pines and perhaps other conifers, as spruce and hemlock. In the last column are placed some 
miscellaneous growths, not of great importance in the aggregate, but prominent in the towns in which they are situated.

Scrub means land covered with acorn brush, or a land covered with young growth of no commercial value.

Pitch pine, in Barnstable, Dukes and Nantucket counties, is put in the pine type.

The cedar referred to is the white cedar (Chamacyparis thyoides) of the swamps, and not the red cedar.

In drawing conclusions from these figures, it is to be noted that the larger the area used the more accurate will the results be; that is, the figures for a county are more accurate than those for a town, and those for the State more accurate than the figures for any county. The columns of per cent. which give the amount of forest land relative to the total area, or the amount of land in each type relative to the total forest area, offer a better means of comparing different towns or counties than the figures of acreage.

Thirty-seven per cent. of the acreage of the State is in forest land; but if Suffolk and Nantucket counties are omitted, the percentage is raised to forty. We add to this an amount sufficient to make up for waste land that should be in forest, and we have about fifty per cent. of the total area of the State available for forest purposes. 


\begin{tabular}{|c|c|c|}
\hline 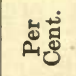 & 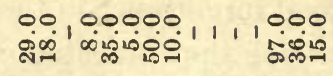 & $\underset{\infty}{0}$ \\
\hline 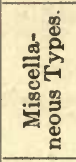 & 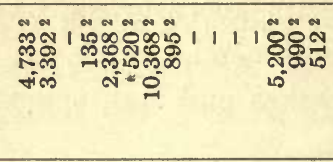 & : \\
\hline 峞莣 & 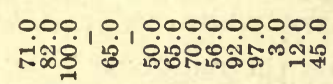 & $\mid \begin{array}{l}0 \\
0 \\
0\end{array}$ \\
\hline 总灾 & 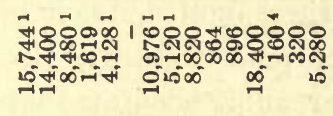 & 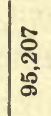 \\
\hline 岁莕 & 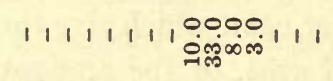 & $\stackrel{0}{\dot{H}}$ \\
\hline 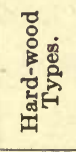 & 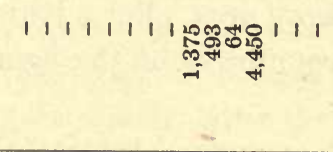 & 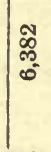 \\
\hline 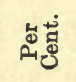 & 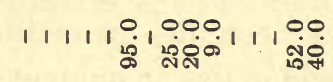 & $\ddot{\circ}$ \\
\hline 离离 & 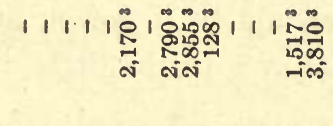 & 尽 \\
\hline 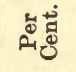 & 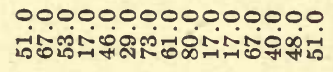 & $\ddot{\ddot{\theta}}$ \\
\hline 总通 & 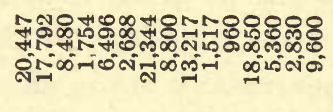 & 望 \\
\hline 离惫 & 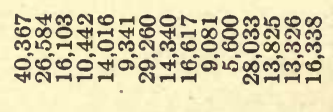 & 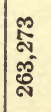 \\
\hline 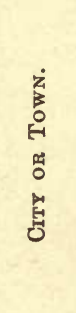 & 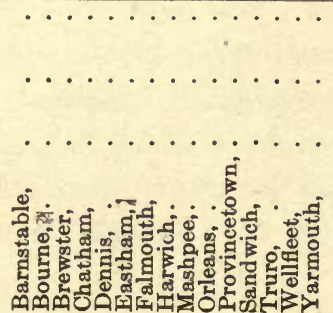 & 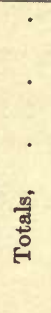 \\
\hline
\end{tabular}

\begin{tabular}{|c|}
\hline 1 । \\
\hline 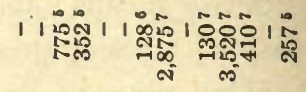 \\
\hline 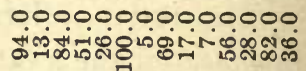 \\
\hline
\end{tabular}

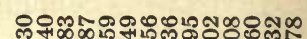
๓ศ్

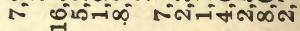

$0,0000,0000,000$

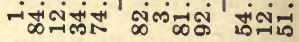

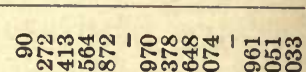

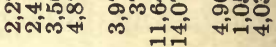

以ण

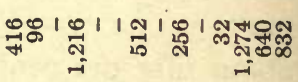

00000000000000 ๓

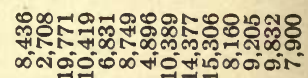

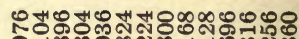
Sษก ผ

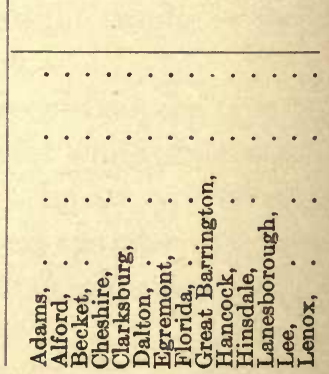




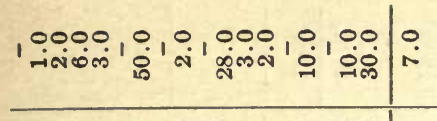

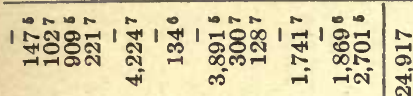

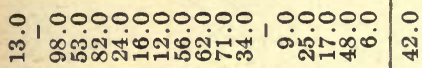

- 1 윰ำ พิ Nำ

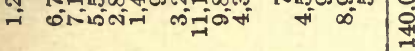

$00,0000000,00000000$

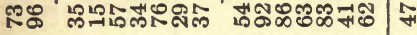

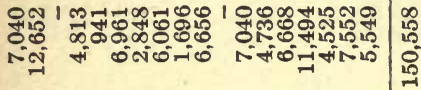

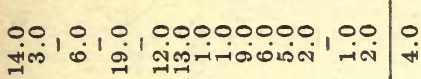

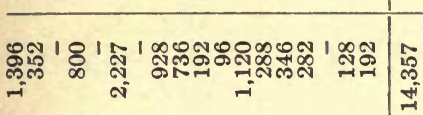
0000000000000000000

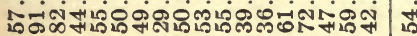

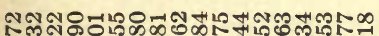

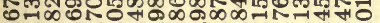

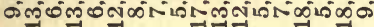
-1 $\rightarrow$ त

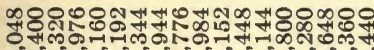
I-100

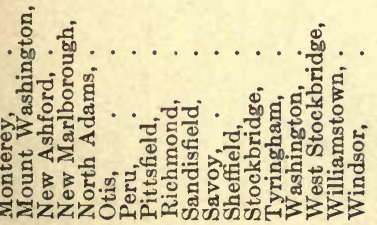

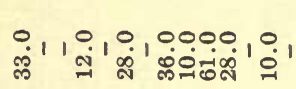

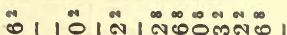

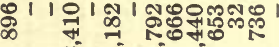

0.0000000000000 भก

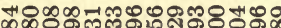
rinifiñ fitio

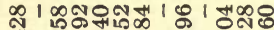

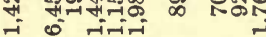

$0,00000,0,000$

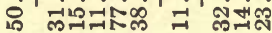

00000,00000000

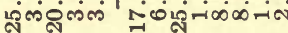

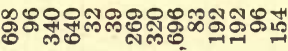

它

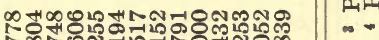

00000000000000 พำ-

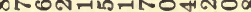
Nivióñ-ino

거푸유요 ON

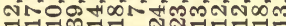

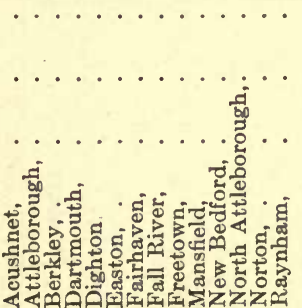




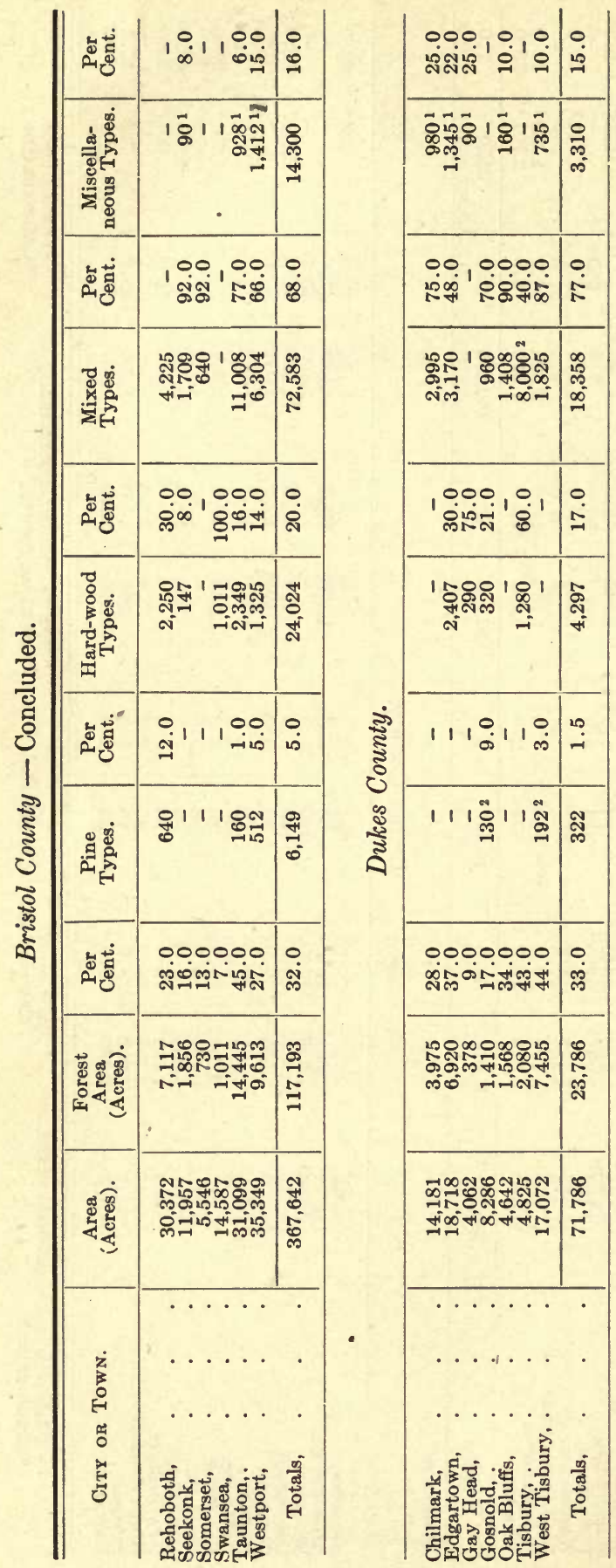

1111111

1111111

, 00000

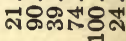

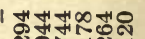

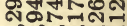

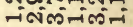

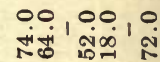

พี⿻

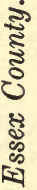
की

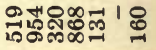

0000000

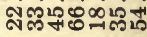

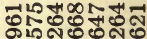

-iōตั

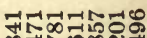

$\infty$ ก

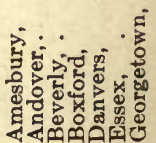




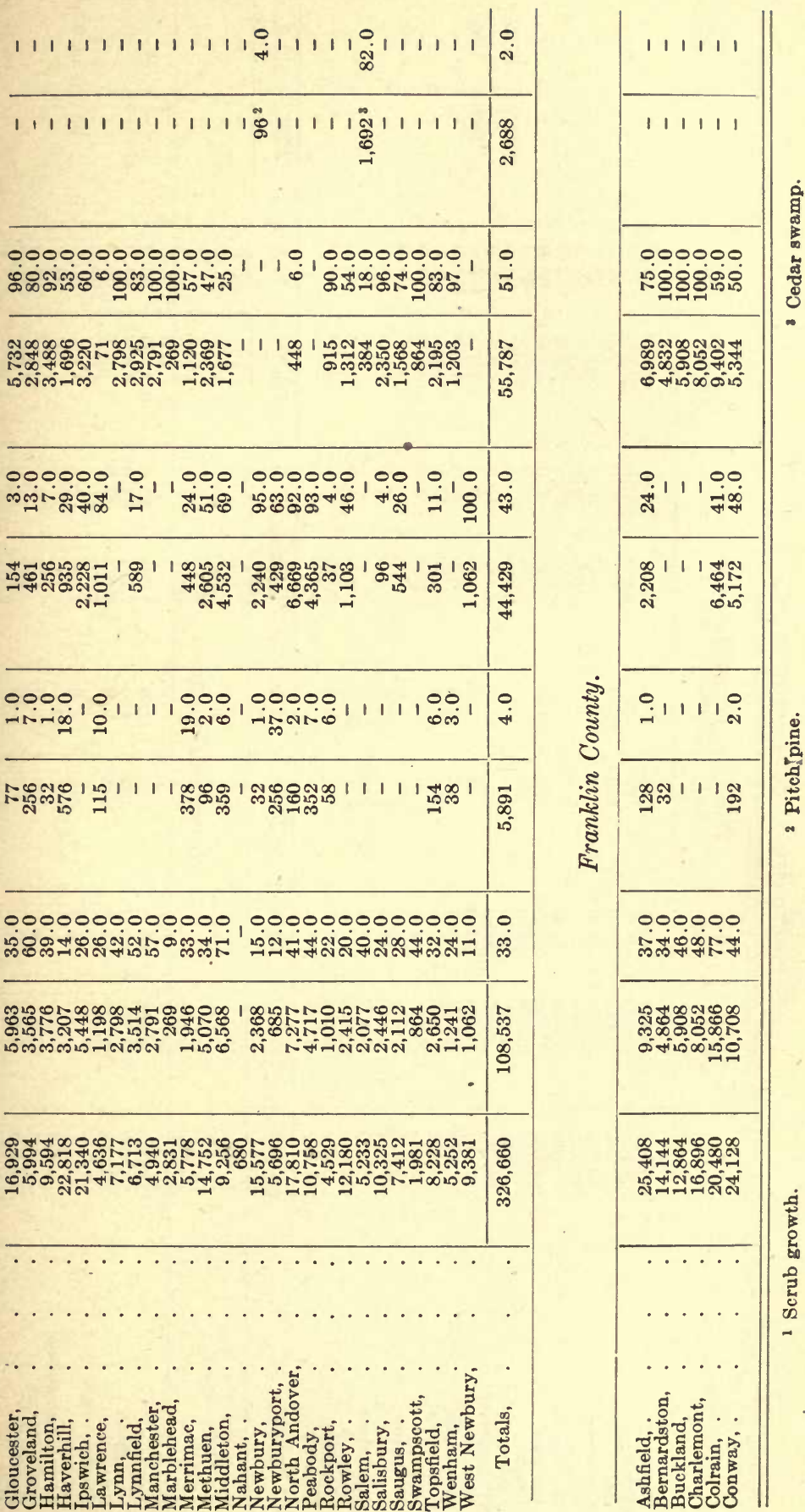




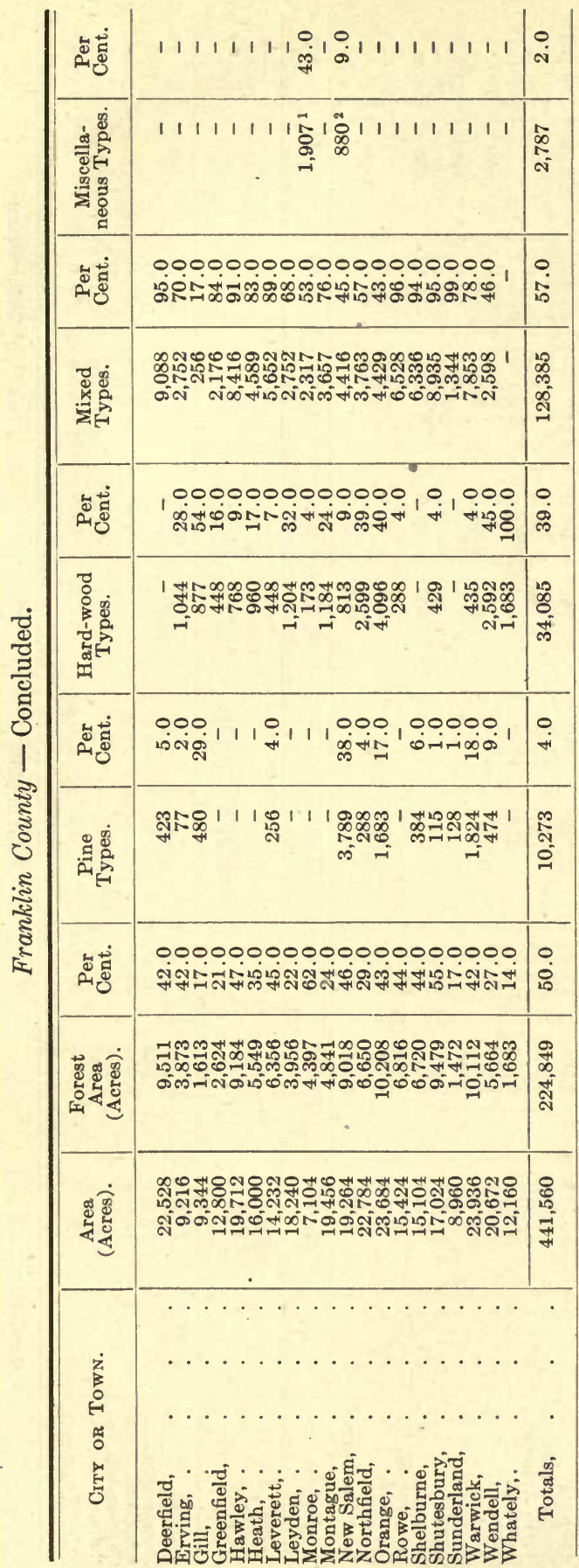

$\begin{array}{lllll}1 & 1 & 1 & 1 & 1\end{array}$

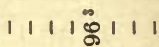

0000,000

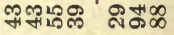

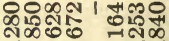
नinti

00000000

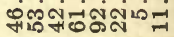

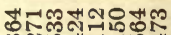
लता मीन नाम -iñón

000,0000

चंमां में

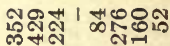

00000000

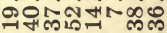

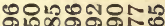
ब1०ल유.10

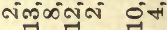

우유유꿍

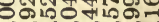

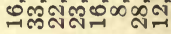

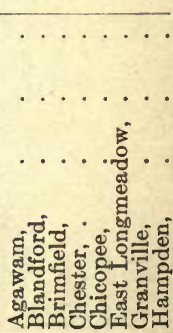




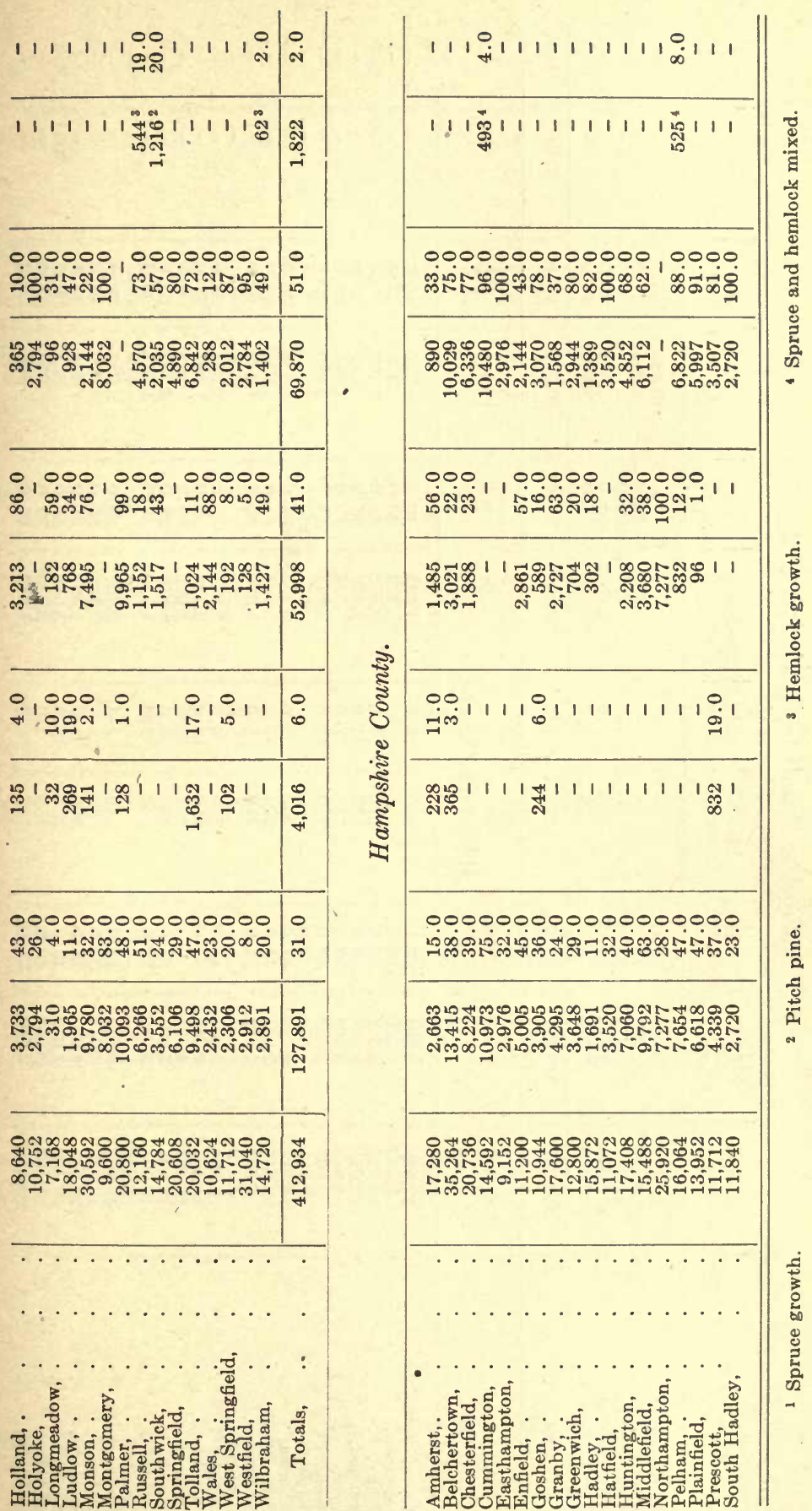




\begin{tabular}{|c|c|c|}
\hline 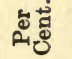 & 111111 & $\stackrel{0}{-i}$ \\
\hline 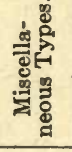 & $\begin{array}{lllll}1 & 1 & 1 & 1 & 1\end{array}$ & $\stackrel{\infty}{\underset{0}{\sigma}}$ \\
\hline ڤึ் & 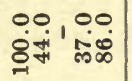 & 0 \\
\hline 递定 & 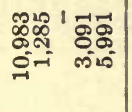 & $\begin{array}{l}8 \\
8 \\
0 \\
8\end{array}$ \\
\hline 犗 & $\begin{array}{l}0000 \\
10000 \\
00 \\
0\end{array}$ & ஜุ. \\
\hline 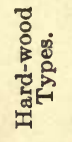 & 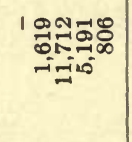 & 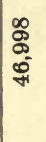 \\
\hline 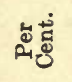 & 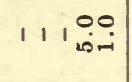 & $\stackrel{0}{i}$ \\
\hline 离 & 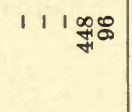 & $\begin{array}{l}n \\
\text { N } \\
\text { v }\end{array}$ \\
\hline 屯் & 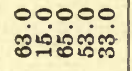 & $\begin{array}{l}0 \\
\infty \\
\infty \\
\infty\end{array}$ \\
\hline 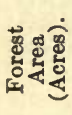 & 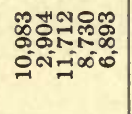 & 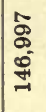 \\
\hline 通惢 & 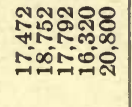 & 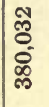 \\
\hline 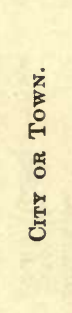 & 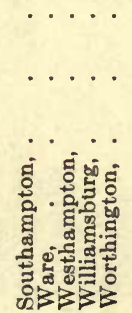 & 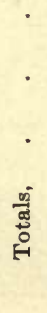 \\
\hline
\end{tabular}

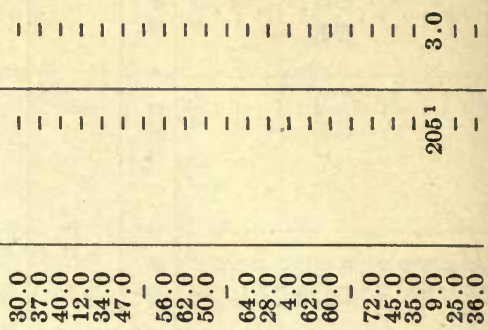

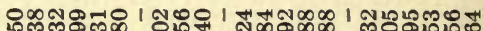
ผan

$0,000000000,00000,000000$

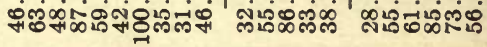

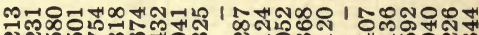
งูल

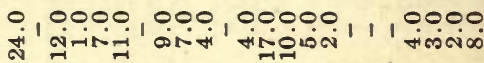

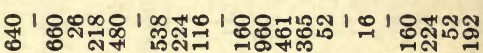

$0000000000,00,00,000000$

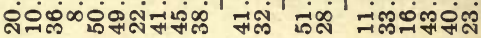

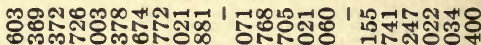

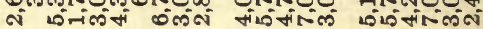

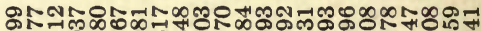

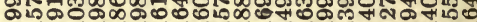
Niñ

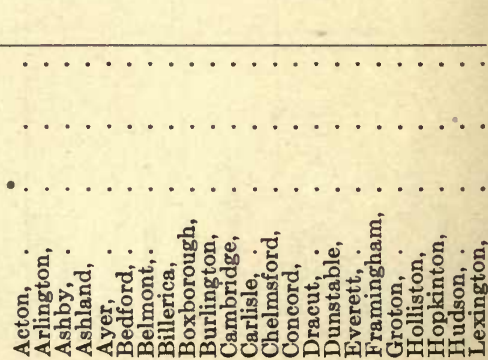




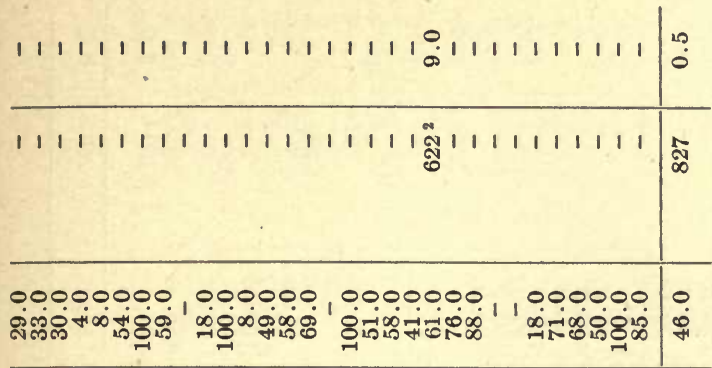

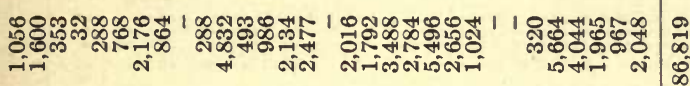

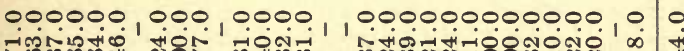

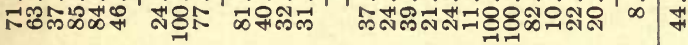

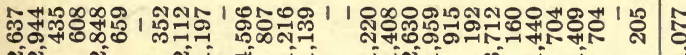

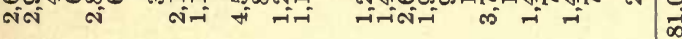

1

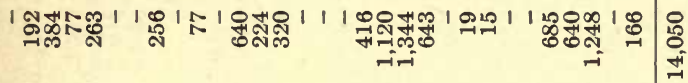

000000000000000,0000000000000000

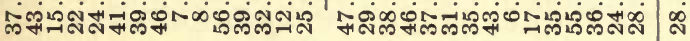

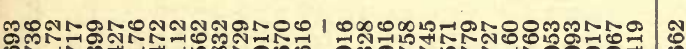

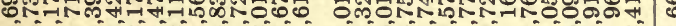

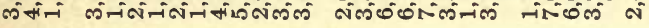

-

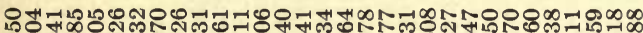

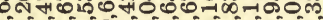
ö-

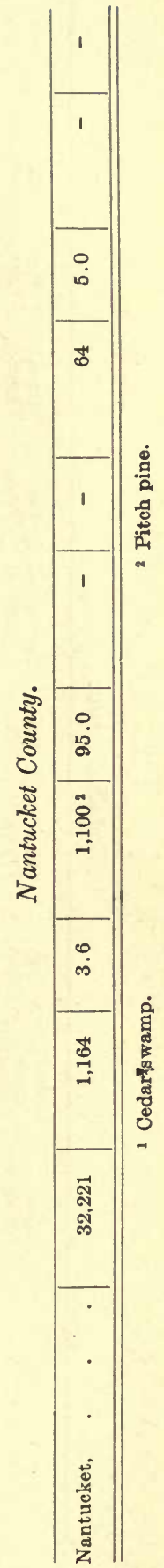

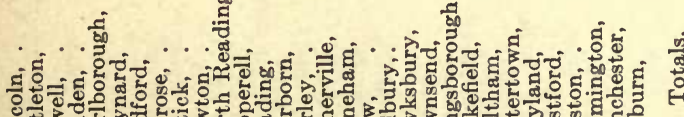

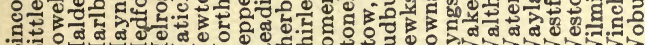

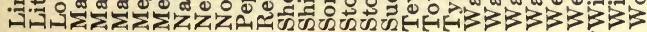




\begin{tabular}{|c|c|c|}
\hline 岁苞 & 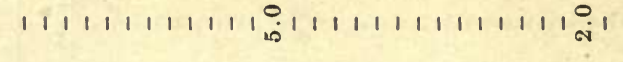 & $\stackrel{\infty}{\circ}$ \\
\hline 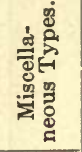 & 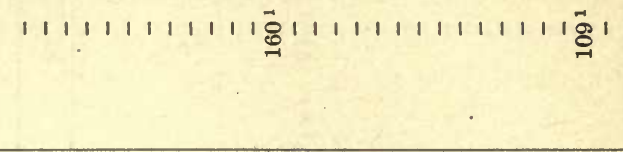 & \&્ \\
\hline 崖苞 & 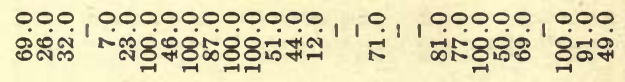 & in \\
\hline 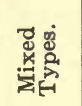 & 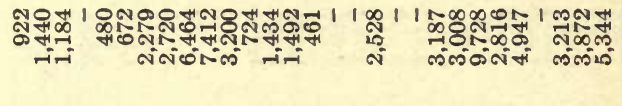 & 周 \\
\hline 㟔 若 & 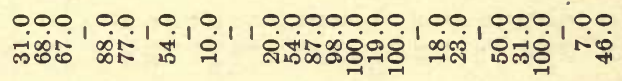 & $\stackrel{0}{\dot{m}}$ \\
\hline 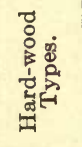 & 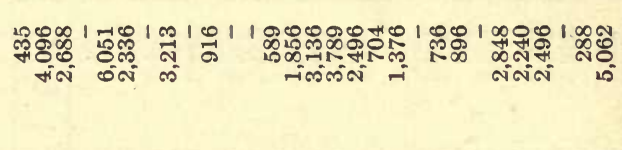 & 勇 \\
\hline 岕苞 & 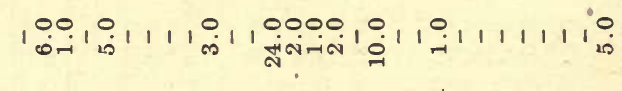 & $\stackrel{\circ}{i}$ \\
\hline 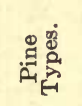 & 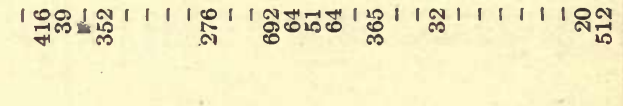 & 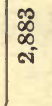 \\
\hline 苍蓠 & 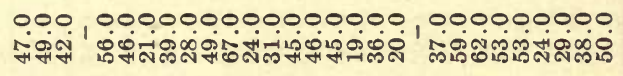 & $\stackrel{\circ}{\stackrel{+}{\sharp}}$ \\
\hline 嶑通 & 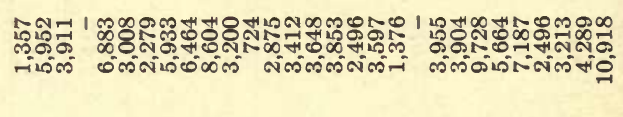 & 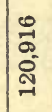 \\
\hline 通 & 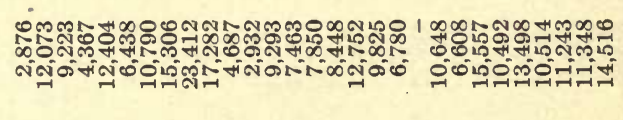 & 蛋 \\
\hline 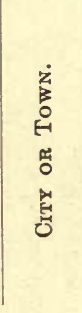 & 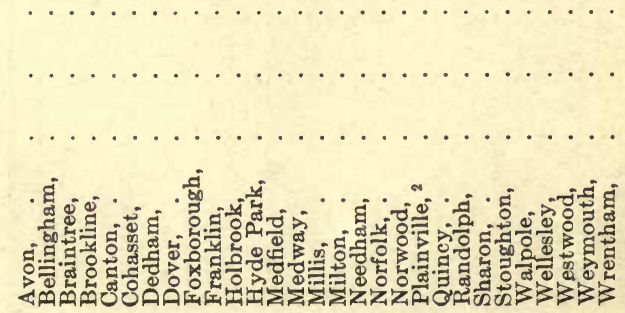 & . \\
\hline
\end{tabular}




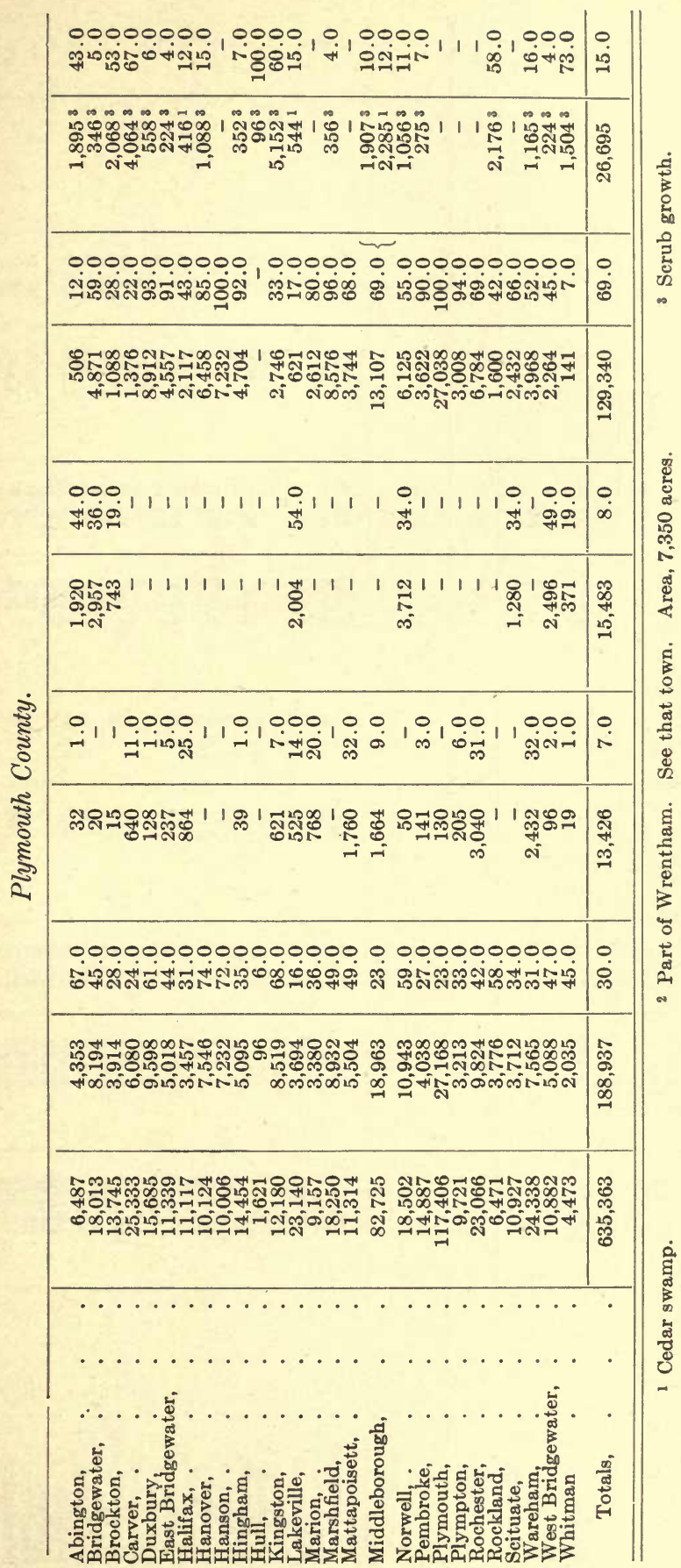




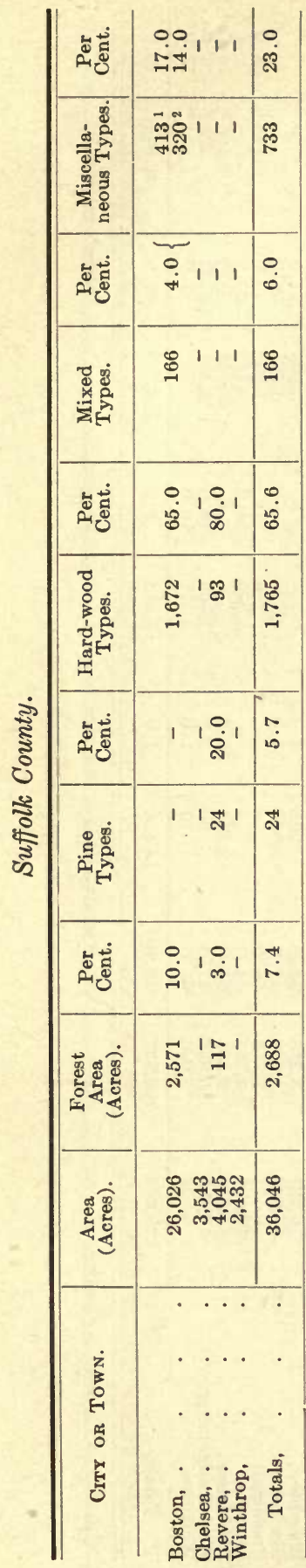

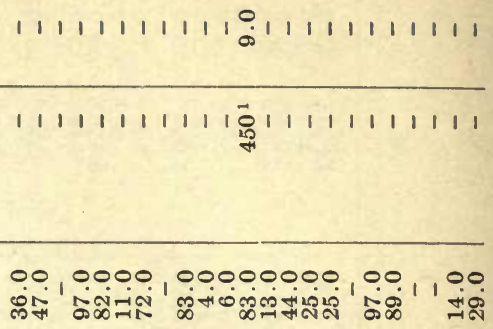

ตูก ' พ⿻ำ

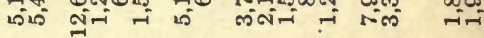

000,0000000000000000000

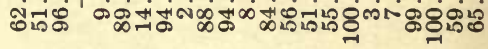

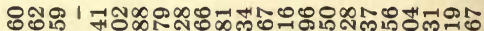

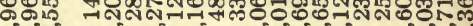

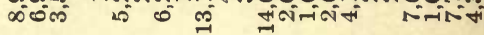

ninimó

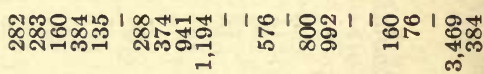

00000000000000000000000 แี่สมผ

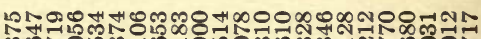

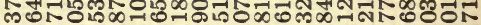
Inmin-

붕ำ

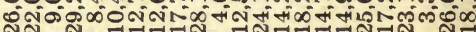

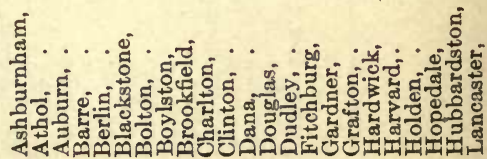


\begin{tabular}{lllllllllllllllllllllllllllllllllllllll|}
1 & 1 & 1 & 1 & 1 & 1 & 1 & 1 & 1 & 1 & 1 & 1 & 1 & 1 & 1 & 1 & 1 & 1 & 1 & 1 & 1 & 1 & 1 & 1 & 1 & 1 & 0 & 1 & 1 & 1 & 1 & 1 & 1 & 0 & 1 & 0 \\
0
\end{tabular}

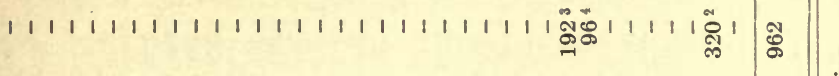

꿍ㅇ I I H नin

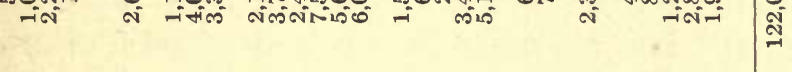

$000000,000,0,000000,0000000000000000$

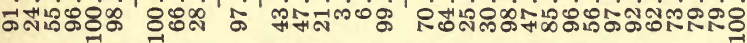

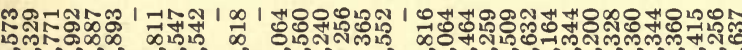

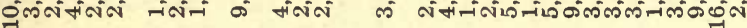

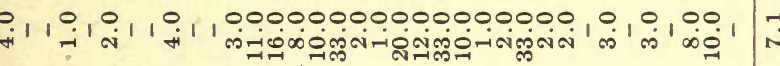
员 1 |

000000000000000000000000000000000000 संผ अ

๕๕๐- Fi

బ้ำ 


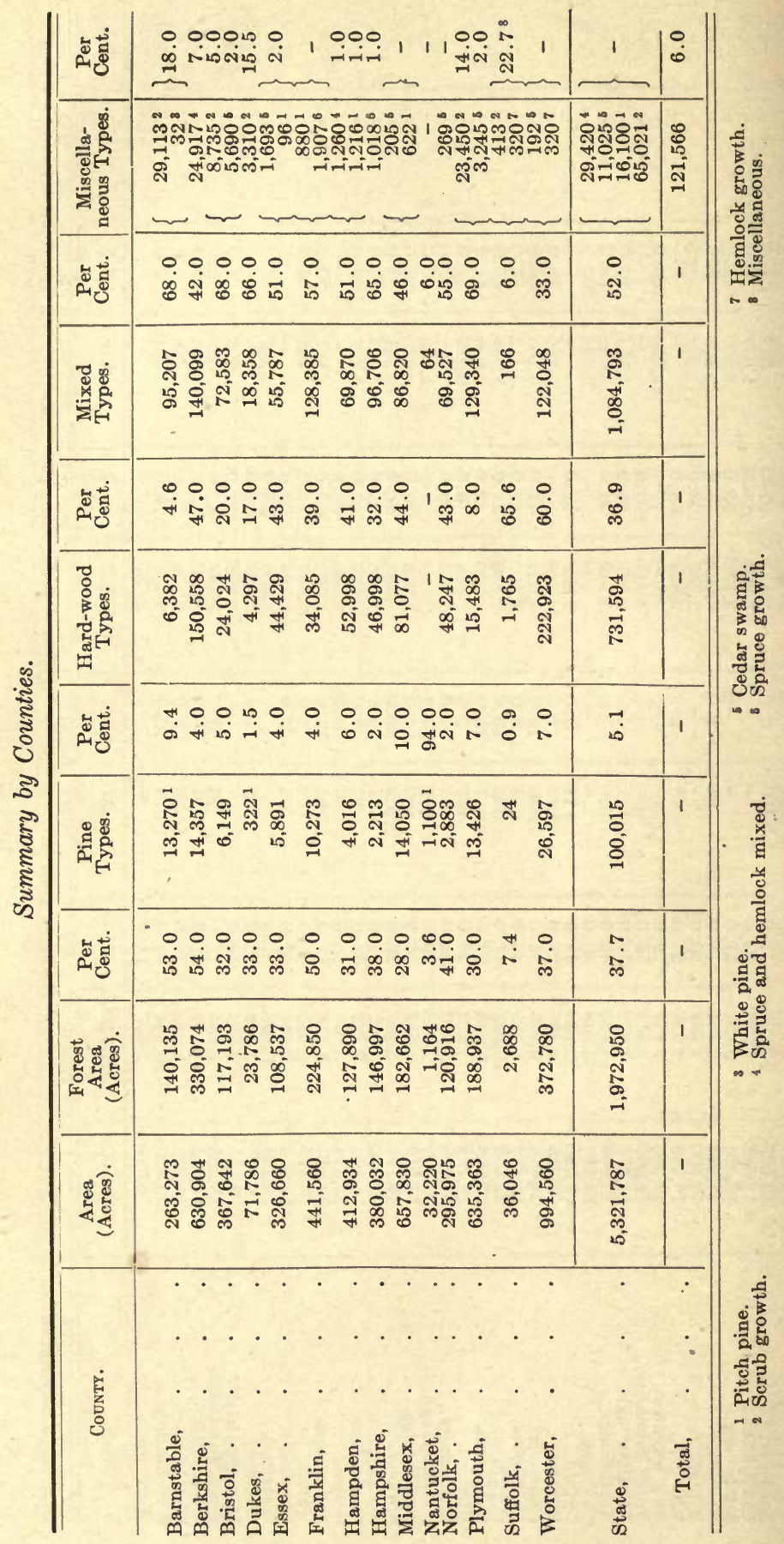




\section{Pine Tree Blight.}

There has been much concern over a condition of the pine trees during the past season. A small per cent of the white pine trees in every section of the State have been affected with a malady which has caused the tips of the needles to turn brown and die. Trees thus affected were very conspicuous, and during midseason, when it was very dry, they took on a very unhealthy appearance. Some trees were more pronounced than others, depending upon just how far down the needles from the tip the so-called "blight" had-spread. All trees, however, even though slightly affected, showed sickly characteristics, in that even the remaining live portions of the tree were lighter in color, and the current seasons growth was much impaired. Both large and small trees were equally troubled, but it was quite noticeable that almost invariably those trees showing the naturally weaker vitality in their struggles for existence were the ones affected. Trees that are badly affected are sure to die, as the evergreens cannot withstand defoliation, in this respect differing from deciduous trees.

As soon as the fall rains came, these trees took on a better color, and the reddish tips, so characteristic during the summer, became inconspicuous or dropped off, so that at present the trouble is not so noticeable. Whether this blight will be as bad again next season is problematical. Trees that have been affected the past season will undoubtedly show the effects in retarded growth and vitality next; and, should the trouble reassert itself, it will probably be advisable to utilize them for timber or wood. In the case of small trees which occur here and there it would be advisable to cut and burn them, as a precautionary method.

The following interview, which appeared in the Boston "Transcript," Aug. 20, 1907, gives a very clear statement of our study of the disease:-

There is much speculation throughout the State as to how serious will be this blight. Land owners who see their trees dying are writing to the State Forester on the subject, asking for information and advice; and it is apparent that it is causing deep concern. In some instances it has attacked favorite trees which from important features of ornamental schemes in parks and on private estates, and large sums of money 
have been offered for treatment that shall save them and cure them. It has been the subject, also, of much scientific study, resulting in conclusions that are somewhat reassuring.

Authorities do not quite agree on the question of time within which it made its appearance in Massachusetts. Some say they have noticed it here for about eight years, while others maintain that its first appearance was three years ago; but they are agreed in the verdict that it is more prevalent this year than in any previous season. Hence the question is raised, Is the disease contagious?

On that particular point State Forester Rane is strongly convinced by his own observations. He has toured certain sections of the State thoroughly in quest of information on that subject, and has studied the woodlands to see what relation one dying tree might have to another. One of his assistants also has made a study in the field, and it is believed that when all the data are pieced together Professor Rane will find it possible to send a reassuring communication on the subject to the land owners.

From all that is at hand to-day, the most logical conclusion is that it is not contagious; and Professor Rane, moreover, ventures to say that it is highly improbable that the disease will spread. It will not be as bad next year as it is now, he thinks. In the first place, he finds blighted pines in the midst of a pine grove, with a few trees practically killed and the others not at all touched by it. A perfectly fresh seedling may be found side by side with a matured tree that is dying, and vice versa, showing that the disease does not spread from one tree to another, and has no preferences based on the age of a pine.

If one tree is more susceptible to an attack than another, it is the naturally dry and unhealthy, consumptive-looking pine, that shows every sign of being underfed; and from this the deduction is drawn that the strong tree withstands and the weak one yields, when exposed to soil and weather conditions that may be productive of the disease. While it is most common on the white pine, it sometimes attacks the pitch pine also, but it is not as common as many persons may have been led to believe. The State Forester, after his investigation, ventured the estimate that the number of affected pines in the State constitute only a fraction of one per cent of the pine stand, but as yet there are no figures available to qualify this estimate. There is enough of it to give rise to apprehension for the pine forest interest, which is one of growing importance in Massachusetts.

State Forester Rane assigned one of his assistants, B. C. Noyes, the other day to go to Winchendon, whence came many inquiries about the disease, to study the condition in that vicinity, and Mr. Noyes makes this report on the subject: "The blight is found on the pines of all ages. Beginning at the tip of the needle, it works downward and gradually spreads over the whole tree. Trees of weak vitality are most liable to be affected. The blight is undoubtedly due to the unusually cold spring, 
followed by excessively hot weather and a period of drought. It has been noticed for several years, but much more so at the present time."

Mr. Charles Bosworth of Winchendon says: "I have noticed the blight for six or eight years, and do not think it serious. This year I noticed it first on one or two trees in the grove in front of my house. These trees are now recovered, while others are affected. In three or four weeks' time I think it will be entirely gone."

Mr. White of Winchendon says: "I have noticed the blight for a long time. One old pine has been in nearly this same condition every year for the past ten years. I do not think it is serious."

Mr. W. H. Brown of Winchendon says: "About two years ago we purchased a tract of growing pine of about six or seven acres. The trees, about a foot high, were at the time pretty generally attacked with the blight, and we hesitated in buying it, on that account. We bought it, however, and to-day it is a thrifty growth, only a few pines being attacked."

Mr. J. G. Folsom, tree warden, says: "I first noticed the blight about six years ago. Just above the village there were several trees affected on both sides of the road. I watched it for two years, and did not notice any increase. The timber on one side was then cut off, but now I cannot find any trace on the trees on the opposite side."

One suggestion as to the cause of it is that some insect has attacked the trees; but in the investigation thus far made nothing has been discovered to substantiate that proposition. There is no sign of animal life on the dead needles, nor have the needles been stung before withering.

Early in the season Professor Rane communicated with Dr. G. E. Stone, at the Hatch Experiment Station, and in a reply to one of the State Forester's letters Dr. Stone writes on the subject as follows: "This trouble has been common since the cold winter of three years ago. I had opportunities to investigate it at that time, and the next year it commenced to show very badly on trees in the form of sun scald, and in the winter in the form of fungi. There were half a dozen fungi found on the pine, but in my estimation all of these were merely the result of the weakened condition of the trees, owing to the severe winter. Dr. Hermann von Schenck and others agree with me.

"My diagnosis of the trouble is as follows: During that cold winter an enormous number of trees were injured, both above and below the ground. I have seen acres of trees, like birches, alders, apple, cherry and a whole host of others, injured at the same time. The pine was injured below as well as above the ground, and I have dug up their roots year after year and found the small ones dead. . . . There was quite a large percentage of the small roots which died, and the dry summer was too hard for them; consequently, the trees suffered from sun scald, and as a result of this and the dying of the tips of the leaves fungi came in after- 
ward. . . . I have had trees under observation since that winter, and know of a great many which have recovered entirely. I gathered specimens of certain trees for my laboratory which are absolutely recovered. This has occurred in all cases where the tips of the leaves were burned back only slightly, but when the needles were killed outright there was no recovery of course.

"I had a great many opportunities to observe this in trees planted in rows and growing in forests, and there was absolutely no indication of any contagion, showing that the fungus was a purely secondary matter. In the Middlesex Fells I found about a dozen of these trees two years ago, and made a careful examination of them, but they were isolated from one another in all cases.

"I have been in consultation with some of the authorities in Washington in regard to this trouble, since I have had a large number of specimens to examine, and do not think there is any difference in our diagnosis. This trouble is also found in other portions of New England, Connecticut and Vermont, and I believe it has been reported in New Hampshire."

Some spraying for this disease has been done in Massachusetts, though it is not now believed that such treatment is of any great value. The trees may be saved, however, says State Forester Rane, if treated in time with the right kind of fertilizer. In case most of the needles on the tree are destroyed, the tree cannot be saved by any kind of treatment; and the forester's advice to the owners of such tree is that they cut it down before it dies if there is lumber in it worth saving. If it is only slightly touched, it may possibly be revived. Three pounds of nitrate of soda to a good-sized tree, spread over the ground as far as the branches reach, will give it vigor enough to get out of the effects of the disease attack.

This remedy has been practised by H. L. Frost \& Co., tree specialists of Boston, with good success for several years.

\section{EquipMent.}

During the past year the State Forester has found it necessary to have some additional equipment for carrying on his work. The principal additions are: two field hand cameras; one surveyor's level; two hypsometers; two aneroid barometers; two right angle finders; a pedometer; a set of book cases and files; and other smaller field implements and drafting room supplies.

\section{Changes in Assistants.}

The State Forester has been very fortunate in having a corps of efficient assistants throughout the year. The only deplorable 
fact is that, as is the usual case, as soon as one's assistants demonstrate their value they are sought after.

Mr. J. J. Dearborn, who has been an assistant in demonstrating practical forestry methods over the State, has done his work so well that the Diamond Match Company has engaged him as their forestry expert. Mr. Dearborn's resignation takes effect February 1.

While the State Forester will miss the valuable service of Mr. Dearborn, he nevertheless will be located with headquarters at Athol in this State and continue in a way to serve the State, although through a private enterprise. The success of $\mathrm{Mr}$. Dearborn can be construed in no other way than a compliment to the effective work of this office during the past year.

Mr. B. C. Noyes, who was also connected with the service until recently, has resigned to accept a position with the firm of H. L. Frost \& Co. of Boston.

\section{EXPENDITURES AND RECEIPTS.}

In accordance with section 6 of chapter 409 of the Acts of 1904, as amended by the Acts of 1907 , chapter 473 , section 2 , the following statement is given of the expenditures for the year ending November 30:

Salaries of assistants, - $\$ 3,18963$ Travelling expenses (not included in co-operative funds), . $\quad 93560$ Instruments, 19646 Stationery and other office supplies, _ . . . . $\quad$. 29308 Printing, . . . $\quad . \quad$. $\quad . \quad$. $\quad . \quad . \quad 87567$

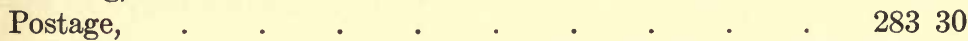

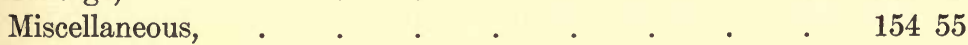

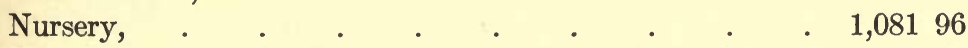

Total, .

There was realized from the sale of seedlings already referred to $\$ 235.50$, which amount has been turned over to the Treasurer and Receiver-General.

In accordance with section 5 of the above-named chapter, the following statement is given of the receipts for travelling and subsistence:- 


\section{For Lectures.}

Everett Grange, Everett, _ . . . . . $\quad$. $\$ 250$

West Newbury Grange, West Newbury, . . . . 187

State Board of Agriculture, Springfield, . . . . . 475

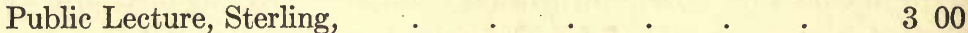

Civic Club, Gleasondale, _ . $\quad$. $\quad$. $\quad 100$

Oakham Farmer's Club, Oakham, . . . . . 300

Grange, Petersham, . . . . . . . 317

Weymouth High School, Weymouth, . . . . 100

Pomona Grange, Lowell, . . . . . 200

Amesbury Board of Agriculture, Amesbury, . . . . 386

Pomona Grange, Methuen, . . . . . . 230

Hardwick Grange, Hardwick, . . . . . 300

Middlesex North Agricultural Society, Westford, . . $\quad 256$

Melrose Woman's Club, . . . . . . 315

Massachusetts Horticultural Society, Boston, . . . 100

Walpole Grange, Walpole, ․ . . . . . . $\quad$. 98

East Sandwich Grange, East Sandwich, . . . . . 300

Middlesex Worcester Pomona Grange, Groton, . . $\quad 250$

Worcester Horticultural Society, Worcester, . . . 450

Field and Forest Club, Dorchester, . . . . . 96

Whitman Board of Trade, Whitman, . . . . 295

North Dana Grange, North Dana, . . . . $\quad 392$

Natural History Club, Bolton, . . . . . $\quad 115$

Springfield Botanical Society, Springfield, . . . $\quad 650$

New England Woman's Club, Boston, . . . . 100

Sloyd Manual Training School, Boston, . . . . . 50

Newbury Grange, Newbury, . . . . . . . 215

State Board of Agriculture, Worcester, . . . . 450

A list of the visits made, the area of woodland involved and the receipts for expenses are as follows:-

II. For Examinations of Woodlands.

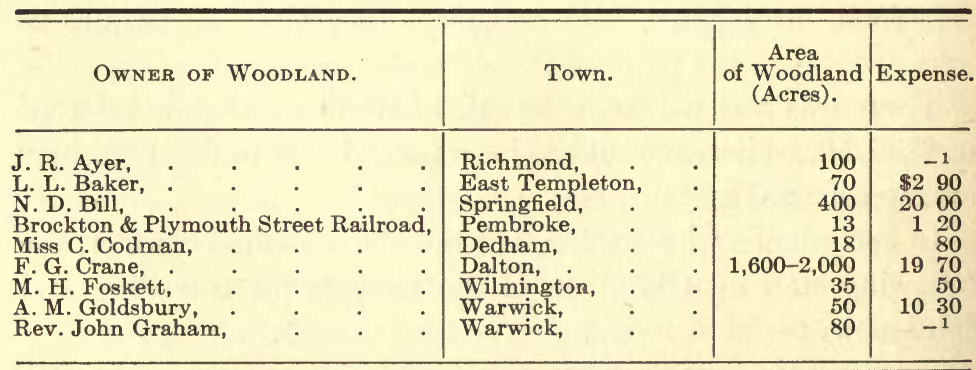


II. For Examinations of Woodlands - Concluded.

\begin{tabular}{|c|c|c|c|c|c|c|c|}
\hline \multicolumn{4}{|c|}{ OWNER OF WOODLAND. } & \multicolumn{2}{|l|}{ Town. } & $\begin{array}{c}\text { Area } \\
\text { of Woodland } \\
\text { (Acres). }\end{array}$ & Expense. \\
\hline $\begin{array}{l}\text { Fiske \& Field, } \\
\text { A. S. Hayes, } \\
\text { Mrs. S. L. Hammon } \\
\text { Rev. N. S. Hoaglan } \\
\text { Dr. R. Hogner, } \\
\text { Rev. C. L. Hutchins } \\
\text { Graham D. Johnson } \\
\text { F. B. Knapp, } \\
\text { Mass. State Hospita } \\
\text { Miss A. McKim, } \\
\text { Dr. H. W. Nelson, } \\
\text { Pontoosuc Woolen } \\
\text { Rev. F. H. Rudd, } \\
\text { Salem Fraternity, } \\
\text { H. W. Shepard, } \\
\text { J. F. Spaulding, } \\
\text { Rev. E. Sturgis, } \\
\text { R. B. Symington, } \\
\text { F. W. Wise, } \\
\text { Ellis G. Wood, } \\
\text { Geo. M. Whipple, } \\
\text { Ormstead Bros., } \\
\text { Frost \& Co., } \\
\text { School for the Feeb } \\
\text { Morris Gray, } \\
\text { Brockton Water Cor } \\
\text { Miss Booth, } \\
\text { Ames estate, }\end{array}$ & 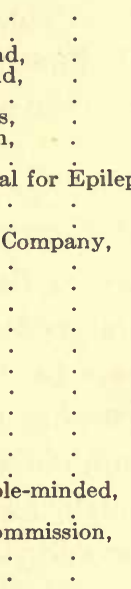 & $\begin{array}{l}: \\
: \\
: \\
\text { ptics, } \\
: \\
: \\
: \\
: \\
: \\
: \\
: \\
:\end{array}$ & . & $\begin{array}{l}\text { Weston, } \\
\text { Hopkinton, } \\
\text { Carlisle, } \\
\text { Warwick, } \\
\text { Mansfield, } \\
\text { Concord, } \\
\text { Andover, } \\
\text { Duxbury, } \\
\text { Palmer, } \\
\text { Warwick, } \\
\text { Marshfield, } \\
\text { Pittsfield, } \\
\text { Richmond, } \\
\text { Rowley, } \\
\text { Salisbury, } \\
\text { Tewksbury, } \\
\text { Andover, } \\
\text { Chiltonville, } \\
\text { Wellfleet,. } \\
\text { Sandwich, } \\
\text { Newburyport, } \\
\text { The Fells, } \\
\text { Arlington and M } \\
\text { Waltham, } \\
\text { Cambridge, } \\
\text { Brockton, } \\
\text { Springfield, } \\
\text { North Easton, }\end{array}$ & 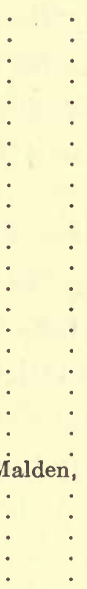 & $\begin{array}{r}100 \\
130 \\
52 \\
30 \\
66 \\
200-300 \\
10 \\
30 \\
200-300 \\
30 \\
108 \\
143 \\
30-40 \\
15 \\
100 \\
25 \\
28 \\
3,000 \\
1,200 \\
100 \\
50 \\
- \\
100 \\
40 \\
10 \\
30 \\
10 \\
100\end{array}$ & $\begin{array}{cc}\$ 0 & 50 \\
1 & 30 \\
50 \\
-1 \\
100 \\
70 \\
797 \\
150 \\
3 \quad 80 \\
-1 \\
120 \\
870 \\
150 \\
120 \\
-2 \\
50 \\
130 \\
320 \\
1465 \\
-2 \\
-2 \\
-2 \\
-2 \\
-2 \\
-2 \\
-2 \\
165 \\
-1 \\
-2\end{array}$ \\
\hline
\end{tabular}

1 No expense.

2 Paid by owner.

\section{What the General Court is asked to consider at Present.}

I. Exemption from Taxation on Forest Land.

At present we have a law in our statutes (Revised Laws, chapter 12 , section 6 ) that is ineffective, as it requires that 2,000 trees must be set on an acre of land to exempt it from taxation, while as a matter of fact 1,210 trees are all that are at present recommended for such purposes. The species of trees for planting are also too small, and the time for exemption I believe could well be extended to twenty years. In Wisconsin similar planting is exempt for thirty years. This law should be amended and modernized to meet our needs.

\section{Forest Reserves.}

It is time that some State forest reserve policy should be established in Massachusetts. The national government is doing much in this direction, and various States have State forest reserves. I would not recommend that this State go into an 
elaborate system of reserves, but if the State Forester could be allowed an appropriation for purchasing cheap lands, and be permitted to replant them for demonstrative purposes, the object lesson would be valuable, and the State could not help profiting thereby financially. It is even possible that some towns or individuals would be willing to give lands to the State, provided they could be accepted and planted by the State Forester. One such offer was made during the year, and it is believed offers of land at low cost can be easily secured.

\section{We must stop Forest Fires.}

After traversing the State and studying conditions carefully, I feel that it will take some drastic mandatory laws in order to cope with the situation. Our people have been so indifferent toward forestry and the protection of forest property that we are absolutely wasting thousands upon thousands of dollars, not only for the present but the future, through sheer negligence. Even much of our so-called scrub growth would yield cord wood, if not lumber, were it not for fires which periodically run over these lands.

With the newly appointed forest warden system better results are expected; but why not clothe this officer with the power to arrest without a warrant any person or persons found in the act of unlawfully setting a fire or trespassing on forest property. This right is given the fish and game wardens; why not the forest wardens and their deputies?

We have a law in our statutes at present (Revised Laws, chapter 32, section 24) which reads as follows:-

In a town which accepts the provisions of this section or has accepted the corresponding provisions of earlier laws, no fire shall be set in the open air between the first day of April and the first day of October, unless by written permission of a forest warden. The forest warden shall cause public notice to be given of the provisions of this section, and shall enforce the same. Whoever violates the provisions of this section shall be punished by a fine of not more than one hundred dollars, to be divided equally between the complainant and the town, or by imprisonment for not more than one month, or by both such fine and imprisonment.

This law, it is believed, should not be left to the discretion of the towns, but should be enacted as a State law. 


\section{The Forest Nursery should be enlarged.}

If we had one million white pine seedlings at the State nursery to distribute at cost, I believe they would all be purchased and set out in Massachusetts this coming year. As a matter of fact, we shall not begin to be able to supply the demand, and already I have placed orders for spring delivery for two hundred and fifty thousand white pine seedlings for Massachusetts people. These seedlings can be raised for less than one-half our people are compelled to pay at the present time. As State Forester, I am very anxious to get just as many trees set on our waste and unproductive lands as possible; and, while nurserymen are adjusting their business to meet the growing demands for young trees, and are unable to supply them even at present high prices, it is well that we encourage our forestry interests by growing seedlings at cost. Were it not for the import duty, transplants (seedlings once transplanted) could be imported from Europe, and all charges paid, cheaper than we can purchase the seedlings themselves in this country.

It takes at least two years to grow white pine seedlings before they are ready to be set out permanently, and three or four years for transplants; hence, if we enlarge our nursery work now, it will be some time before the plants are ready for distribution.

Besides white pine, there are many other species of forest trees that should be propagated for dissemination.

I would recommend that the nursery work be increased to at least four times its present capacity. While the first cost would seem large, nevertheless, in from two to four years the money would be returned to the State from the sale of seedlings.

\section{$V$. Increased Appropriation needed.}

While the State Forester deplores the necessity for asking for increased appropriations for his work, he nevertheless feels that it is his duty to do so. While, as has already been shown, the money for both increased nursery work and forest. reserves will be returned to the State ultimately, nevertheless, such appropriation must be made to begin with. Five thousand dollars could be used to advantage in enlarging the nursery, and for a system of forest reserves for which the first cost would be relatively large, it is recommended that an appropriation be made. 
The regular appropriation for running expenses for the past year was at the rate of $\$ 10,000$ a year. This amount is asked for the present year.

Beginning with the spring town elections, according to the law passed last year, the new town forest warden law goes into effect. In order to establish the work as it should be, and encourage each town to do more thorough and definite work, a State appropriation of $\$ 10,000$ is recommended. Of this amount, $\$ 2,000$ is to be used for holding a convention as stated in the law, and the remainder used in paying forest wardens in various towns for actual service rendered in their respective towns in securing data and rendering services when called upon by the State Forester.

This recommendation applies equally to all towns of the State, as, if it were left to the towns themselves, many would very likely be indifferent; therefore, it is believed it becomes a matter for State legislation. All bills of forest wardens for services rendered at the request of the State Forester must be approved by that office; hence there is good assurance that the money will be strictly used for bettering forestry conditions everywhere in the State. The State Forester even hopes for example, to so educate his wardens that they may be on the lookout and report upon such insects as the gypsy moths should they invade new territory.

Only through forethought and system can we expect to accomplish in forestry what all our citizens would like to see.

\section{Summary of Recommendations.}

1. That the law relative to the exemption from taxation of lands set to forest trees be amended.

2. That a system of forest reserves for the State be established, and funds for their purchase and maintenance be created.

3. That the State Forester and his authorized employees and the forest wardens and their authorized deputies be given the same power of arresting persons found in the act of unlawfully setting a fire that the fish and game deputies now have.

4. That the law relative to permission to set fires in the open be amended, and made mandatory to the whole State.

5. That the appropriation for the State Forester's office be the same as last year, $\$ 10,000$, but that an additional $\$ 15,000$ be 
made for the purpose of increasing the State nursery work, holding the convention of forest wardens, and recompensing these men for their assistance in the broader State forestry work as required under direction of the State Forester.

6. That the State Forester's annual report be made a public document.

Respectfully submitted,

F. W. RANE,

State Forester. 

Wrotem Muthes

FIFTH ANNUAL REPORT OF THE STATE FORESTER OF MASSACHUSETTS FOR THE YEAR $1908 * * * * *$

\section{FRANK WM. RANE}

STATE FORESTER

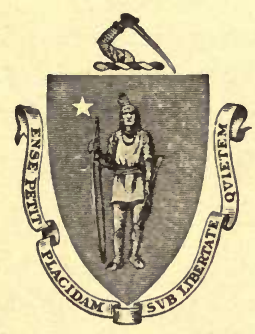

Approved by the State BoARd of Publication

BOSTON

WRIGHT \& POTTER PRINTING COMPANY, STATE PRINTERS 18 POST OfFice SQuare 



\section{CONTENTS.}

New Legislation:-

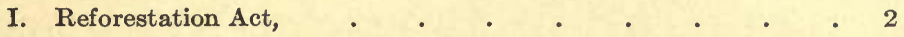

II. Forest Fire Protection Act, - . . . . . 7

III. Revised Laws on Exemption of Reforested Lands from Taxation, 8

IV. A Resolve authorizing the Sale of Certain Publications, . 9

Examinations of Woodlands, and Practical Assistance given Owners, $\quad 11$

Forest Nursery, . $\quad . \quad$. $\quad$. $\quad$. . . . . . 15

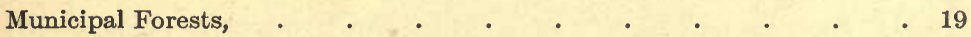

Public Lectures and Addresses, . . . . . . . $\quad$. 20

Lectures before Business Men's Organizations, . . . . . 21

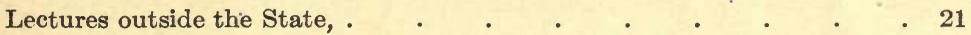

The National and State Conservation Commissions, . . . . 21

The National Irrigation and Forestry Congress, . . • • . 22

Meeting with the State Firemen's Associations, . . . . . 22

Pine Tree Blight, . . . . . . . . . . 23

Forest Fires, . . . . . . . . . . . . 24

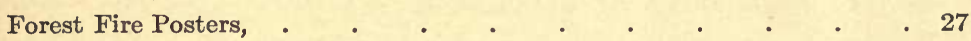

Forest Mensuration of White Pine, . . . . . . . 28

Good Roads a Benefit to Modern Forestry, . . . . . 28

Tenth Anniversary of the Biltmore Forestry School, $\quad$ $\quad$ $\quad$ $\quad$. 29

Co-operation with the United States Forest Service and Forestry Officials

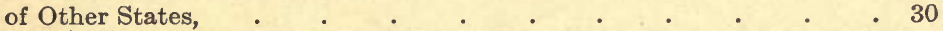

Forestry Information to the Press, . . . . . . 30

Metropolitan Water and Sewerage Board Planting Data, . . . 35

Assistants, . . . . . . . . . . . . 39

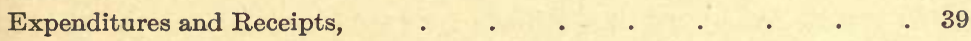

What the General Court is asked to consider at Present, _ . . . 43

Summary of Recommendations, . . . . . . . . 46 



\section{(ommonwealth of $\mathfrak{A l}$ assachusetts}

\section{FIFTH ANNUAL REPORT OF THE STATE FORESTER.}

To the General Court.

It is with continued pleasure that I submit this, the fifth annual report of the State Forester of this Commonwealth.

The office has increased in usefulness, and the work along all lines has been greatly enlarged. With forest products in constantly increasing demand, and thus all kinds of woods quickly finding a ready market, our people realize that right here in Massachusetts much of our cheap lands can be made more productive, and hence valuable in proportion to how well we care for them.

The forest warden act first went into effect last spring, and, although we have had but one season to test its efficiency, there can be no doubt but that this one natural channel of definite authority and usefulness will work wonders in establishing a successful State forest policy. These 343 forest wardens, one in each town and city with forested area, have already done valiant service, and when they are more experienced and are given public-spirited encouragement by our people throughout the State, they are bound to become great factors for good everywhere. With such an army of men enlisted to do service not only for their respective communities but in the aggregate for the State as a whole, results must come.

The work of making examinations and giving advice on forestry matters has grown even beyond our expectations. The correspondence has been very much larger, but more 
readily handled, due to the available literature published last year and this.

The continued hearty co-operation and cordial assistance heretofore rendered to the State Forester have not been wanting this year. After due consideration and study of our forestry needs, some bills were presented before the last General Court which met with approval and were enacted. As on similar occasions heretofore, the forestry interests at the hearings before the Legislature were represented by all our forestry and agricultural organizations, and by publicspirited citizens. In fact, I do not believe I am over-stating conditions when I say that Massachusetts citizens generally are in accord in requesting you, the General Court, to enact as many laws as are necessary to regulate and establish a sane and practical system of forest management throughout this Commonwealth.

\section{New Legislation.}

The new legislation enacted by the last General Court on forestry matters was as follows:-

I. Reforestation act.

II. Forest fire protection act.

III. Revised Law on exemption of reforested lands from taxation.

IV. A resolve authorizing the sale of certain publications of the State Forester.

\section{Reforestation Act.}

The enactment of the bill on reforestation, introduced by Senator Treadway, marks the beginning of a practical demonstration of forest planting throughout the State. This work, it is believed, will prove not only of great economic importance, but be a great factor in practically demonstrating what can be actually accomplished. There is very little excuse henceforth for those of us who own run-out or cheap lands not to make use of them, as the State is ready to meet us more than half way. 


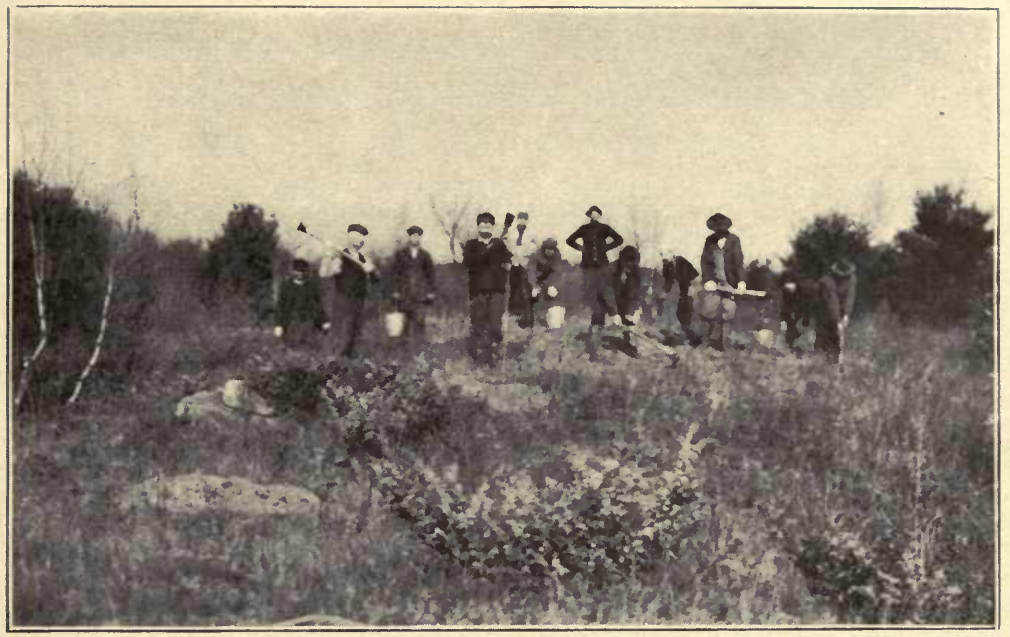

THE First GaxG To Begis l'LANTiNG. - They are working under the reforestation law of Mass:tchusetts, Norember, 190s, at South A shburuham. Several hundred acres will be set next spring. 

The bill is as follows:-

Acts of 1908, Chapter 478.

AN Act to provide for the Purchase of Forest Land and for ReForestation.

Be it enacted, etc., as follows:

SeCtion 1. For the purpose of experiment and illustration in forest management and for the purposes specified in section seven of this act, the sum of five thousand dollars may be expended in the year nineteen hundred and eight, and the sum of ten thousand dollars annually thereafter, by the state forester, with the advice and consent of the governor and council, in purchasing lands situated within the commonwealth and adapted to forest production. The price of such land shall not exceed in any instance five dollars per acre, nor shall more than forty acres be acquired in any one tract in any one year, except that a greater area may so be acquired if the land purchased directly affects a source or tributary of water supply in any city or town of the commonwealth. All lands acquired under the provisions of this act shall be conveyed to the commonwealth, and no lands shall be paid for nor shall any moneys be expended in improvements thereon until all instruments of conveyance and the title to be transferred thereby have been approved by the attorneygeneral and until such instruments have been executed and recorded.

SECTION 2. The owners of land purchased under this act, or their heirs and assigns, may repurchase the.land from the commonwealth at any time within ten years after the purchase by the commonwealth, upon paying the price originally paid by the commonwealth, together with the amount expended in improvements and maintenance, with interest at the rate of four per cent per annum on the purchase price. The state forester, with the approval of the governor and council, may execute in behalf of the commonwealth such deeds of reconveyance as may be necessary under this section: provided, however, that there shall be included in such deeds a restriction requiring that trees eut from such property shall not be less than eight inches in diameter at the butt.

SECTION 3. The state forester may in his discretion, but subject to the approval of the deed and title by the attorney-general as provided in section one, accept on behalf of the commonwealth gifts of land to be held and managed for the purpose hereinbefore expressed. A donor of such land may reserve the right to buy back the land in accordance with the provisions of section two, but in the absence of a provision to that effect in his deed of gift he shall not have such right. 
SeCtion 4. Land acquired under the provisions of this act shall be under the control and management of the state forester, who may, subject to the approval of the governor and council, eut and sell trees, wood and other produce therefrom.

Section 5. All moneys received by or payable to the commonwealth or any one acting on its behalf under the provisions of this act shall be paid into the treasury of the commonwealth.

SECTION 6. Land acquired under the provisions of this act and subsequently reconveyed under the provisions of sections two or three shall not be exempt from taxation on account of any plantation of trees set out or planted while it was held by the commonwealth.

SeCTion 7. For the purpose of assisting in reforestation a portion, not exceeding twenty per cent of the money authorized by this act to be expended may be used by the state forester for the distribution at not less than cost of seeds and seedlings to land owners who are citizens of the commonwealth, under such conditions and restrictions as the state forester, subject to the approval of the governor and council, may deem advisable.

SeCTion 8. The state forester shall replant or otherwise manage all land acquired by the commonwealth and held by it under the provisions of this act, in such manner as will, in his judgment, produce the best forest growth both as to practical forestry results and protection of water supplies.

SeCTION 9. All acts and parts of acts inconsistent herewith are hereby repealed.

SeCtion 10. This act shall take effect upon its passage. [Approved May 1, 1908.

As above indicated, this bill was approved May 1, 1908, and, as the planting season begins as soon as the frost leaves the ground in the spring, we were unable to make use of the appropriation until later in the year.

In order to bring the enactment to the attention of our people, and to make the first year's appropriation go as far as possible, the following general letter was sent out to all the chairmen of the boards of selectmen of our towns, newspapers, agricultural organizations, women's clubs, etc.:-

Dear Sir:- The recent General Court enacted a law authorizing the State Forester, subject to the approval of the Governor and Council, to establish a system of forest reserves for promoting the forestry interests of the Commonwealth of Massachusetts (chapter 478, Acts of 1908).

The amount appropriated for this year is $\$ 5,000$, and succeeding years, $\$ 10,000$ annually. 
In order to make the appropriation as useful as possible, I am addressing the chairman of the board of selectmen in each town, also all organizations and persons likely to be interested, asking if they have any lands they desire to turn over to the State for forest demonstration purposes. As many acres have already been offered to the State, provided the State Forester will accept and reforest them, and as it is believed that there are many more that would do likewise, I take this opportunity to bring the matter to your attention, and through you to your board, town and public interests.

Should your town authorities neglect to take advantage of this offer, you undoubtedly have some live, enthusiastic organizations, such as the grange, village improvement societies, farmers' and mechanies' clubs, etc., or even one or more public-spirited eitizens, who would gladly donate cheap lands for the purpose. The donations for consideration are to be in the following classes: (1) land offered to the State free without restrictions; (2) land offered to the State free with restrictions.

As the work of reforestation thus done is to serve as an object lesson educationally, the State Forester desires in so far as possible to ultimately have these demonstrative forestry experiments in various representative sections of the State, locating them on frequently travelled roads, where they may do the most good.

Should you find an interest in your town to take this matter up, please advise me. It is desired that this work be gotten well in hand, so that all plans may be matured and the definite arrangements made where this work is to go forward.

Only a limited appropriation is available, and if you care to have your town do something, please take the matter up at an early date and confer with me.

It is believed much good is to come from this work, in promoting a better utilization of our waste and neglected lands, that should and will produce valuable forest products when properly husbanded.

When your application is received, it will be filed, and as soon as a date can be arranged, the State Forester or his authorized agent will meet with you or your committee and go over the land to complete arrangements for accepting and planting the same. First come, first served!

$$
\text { Very sincerely yours, }
$$

F. W. Rane, State Forester.

State House, Boston, Mass.

The outcome of this agitation has resulted in the State's taking over by the end of the fiscal year, Nor. 30, 1908, 882 acres of land and purchasing about a million and a half of seedlings and transplants. We also planted about 25 acres to white pine at South Ashburnham this last fall. 
The above work exhausted our first appropriation, and we are now prepared to begin the work of reforestation in earnest, as soon as the frost leaves the ground in the spring.

During this winter we are planning our next year's campaign, and already have many tracts of land in view in various sections. In order to take these lands over, besides an examination as to their suitability for reforesting, much time is necessary to make the necessary survey and transfer of the title to the State.

Of the 1,000 acres turned over to the State thus far, only 160 acres have been purchased, the remainder simply being deeded to the State at no expense. In nearly every instance the owners have inserted the repurchasing clause, so as to regain the property within ten years.

\section{Lands acquired by the State.}

Up to the present the State Forester has deeds in his possession from the following towns:-

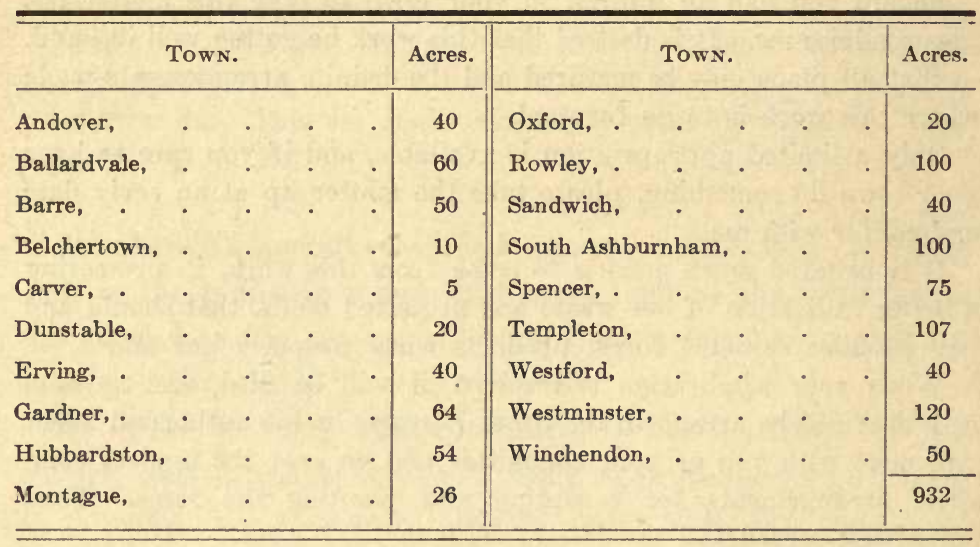

In this work of reforestation it is my plan to utilize the local forest wardens whenever practicable, of course under proper State supervision, and thus in time the State will have a corps of reforesting experts.

One hundred thousand Scotch pines have been shipped to Sandwich and heeled in this fall, for use in planting on the Cape next spring. 


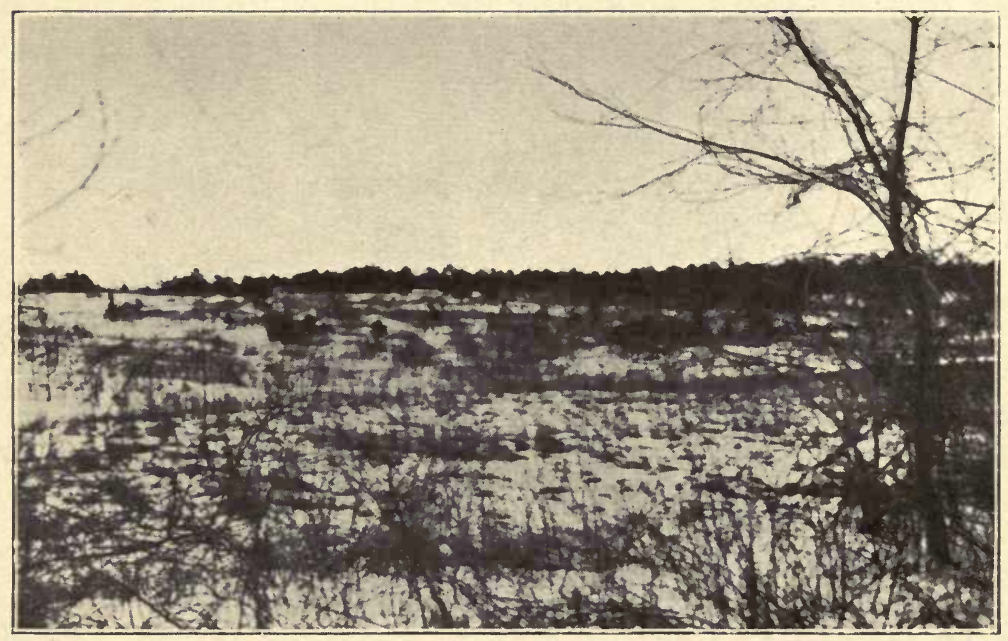

As Abaxdonel Massachusetrs Field. - Nature is trying tu reforest; man can assist, and quick results will follow. 

Of course this work is but in its infancy, but it is believed that our people generally will appreciate this forward movement, and as soon as they realize the generous offer on behalf of the State they will be quick to accept the assistance offered.

With our depleted, neglected and waste lands reharnessed and made a live factor throughout Massachusetts, one of our natural resources will be headed in the right direction. In one town a prominent business man said that the agitation and taking over of lands by the State for reforestation have increased valuations of farming property fully $15^{\prime}$ per cent already. If this is true, it must follow that when actual results are shown, the benefits are bound to be still greater.

\section{Forest Fire Protection.}

This act is bound to accomplish good results. One of the greatest drawbacks to a stalwart progressive movement in forestry is the destruction and wanton waste caused by fires.

The time has come when the towns throughout the State must give a reasonable degree of assurance to their citizens that they are to be protected against losses by fire, if they expect people to invest time and money in reforestation and to build up a proper forest policy.

The following law was enacted in order to regulate and lessen forest fires everywhere. Here is an opportunity for the towns to clothe their forest wardens with power to accomplish results. If all our public-spirited people will give this law proper consideration, and accept the permit clause at the spring annual town elections this year, forest fires are bound to decrease. It is not the purpose of the law to take away personal liberties, but to conform the regulations for the benefit of the common good. Our towns throughout this State will be in the future what we make them. The following is the act: -

Acts of 1908, Chapter 209.

An ACt to provide for the Protection of Forest or Sprout LANDS From Fire.

Be it enacted, etc., as follows:

SECTION 1. In a town which accepts the provisions of this act or has accepted a corresponding provision of earlier laws no fires shall 
be set in the open air between the first day of April and the first day of December, except by the written permission of the forest warden: provided, that debris from fields, gardens and orchards, or leaves and brush from yards may be burned on ploughed fields by the owners thereof, their agents or lessees, but in every case such fire shall be at least two hundred feet distant from any forest or sprout lands, and shall be properly attended until it is extinguished. The forest warden shall cause public notice to be given of the provisions of this section, and shall enforce the same. Whoever violates the provisions of this section shall be punished by a fine of not more than one hundred dollars, or by imprisonment for not more than one month, or by both such fine and imprisonment.

SECTion 2. The provisions of the preceding section shall not apply to fires which may be set in accordance with regulations and methods approved by the superintendent for suppressing the gypsy and brown tail moths.

SECTion 3. The state forester shall notify every town in the commonwealth of the passage of this act by sending at least three printed copies thereof to the town clerk, who shall post the same in conspicuous places.

SECTION 4. The state forester and forest warden may arrest without a warrant any persons found in the act of setting a fire in violation of any provision of this act.

SECTION 5. The selectmen of every town shall cause this act to be submitted to the voters for their acceptance at the next annual meeting of the town after the passage of this act. The vote shall be taken by separate ballot, and shall be "Yes" or "No" in answer to the following question printed upon the ballot: "Shall an act passed by the general court in the year nineteen hundred and eight, entitled 'An Act to provide for the protection of forest or sprout lands from fire' be accepted by this town?" A majority vote of the legal voters present and roting at such meeting shall be required for the acceptance of this act; and upon such acceptance the provisions of section twenty-four of chapter thirty-two of the Revised Laws shall cease to apply to any town which has previously accepted that section. [Approved March 14, 1908.

\section{The Revised Latws on Exemption of Reforested LaNdS From Taxation.}

The old law (R. L., c. $12, \S 6$ ) required that in order to get planted lands exempt from taxation at least 2,000 trees must be set to the acre. As 1,200 trees is the number commonly recommended, or 6 by 6 feet, this revision was necessary. The new revision also allows the filling out of naturally stocked lands, so that they may receive similar exemp- 
tion. This ought to encourage some renewed efforts in that direction. The following is the act:-

\section{Acts of 1908, Chapter 120.}

An Act relative to the Taxation of Plantations of Certain VARIETIES OF TrEes.

Be it enacted, etc., as follows:

Chapter twelve of the Revised Laws is hereby amended by striking out section six and inserting in place thereof the following:Section 6. Land upon which pines, chestnuts, larches, spruces, hemlocks, walnuts, hickories, American and large-toothed poplars, yellow and paper birches, beeches, maples, basswoods, or ash timber trees, or others when approved by the state forester, have been set out or planted to the number of not less than six hundred per acre, and which by such setting out or planting has become evenly stocked with such trees to the number of not less than twelve hundred per acre, including in such number the trees growing naturally upon said land, shall be exempt from taxation for a period of ten years after the said trees have grown in height two feet on the average, upon satisfactory proof by the owners to the assessors of the foregoing facts: provided, that at the time when the trees are planted or set out the said land is not woodland or sproutland, or land containing more than six hundred standing trees to the acre, and does not exceed in value ten dollars per acre; and provided, further, that such exemption shall not extend beyond the time during which said land is devoted exclusively to the growth of said trees. [Approved February $25,1908$.

\section{Authorization for the Sale of Certain Publi- cations of the State Forester.}

Certain publications of this officer were so much in demand that to meet the same would be a financial burden, and as many of those desiring the publications expressed a willingness to pay for them if it were possible, the following resolve has been passed, enabling the State Forester to sell certain publications at cost, when sanctioned by the Governor and Council. The following is the resolve:-

Acts of 1908, Chapter 121.

Resolve to authorize the Sale of Certain Publications of the State Forester.

Resolved, That such publications of the state forester as shall be designated by the governor and council may be sold by the state 
forester at a price not less than the cost thereof; and additional copies may be printed for sale at the discretion of the governor and council, the expense thereof to be paid from the receipts from such sales. Any amounts received from such sales shall be paid into the treasury of the eommonwealth. [Approved June 1, 1908.

Many of the publications have been sent to other States since this resolve was passed. Upon its passage the following letter was sent to all applicants, and new editions have been printed:-

Dear Sir or Madam:- Your application for either or both of the following forestry publications has been received:-

(1) "The Commercial Forest Trees of Massachusetts: how you may know Them. A Pocket Manual." For general use.

(2) "The Study of Trees in Our Primary Schools." For teachers, mothers, and all interested in teaching children to love trees and nature.

Under the Resolves of 1908 (ehapter 121), the Governor and Council have designated that these publications be sold by the State Forester at a price not less than the cost thereof; and additional copies may be printed, the expense thereof to be paid from the receipt of such sales.

I am empowered to offer the above-named publications to you at the following prices:-

(1) The Pocket Manual, "The Commercial Forest Trees of Massachusetts: how you may know Them," for 5 cents a copy at this office, or by mail for 2 cents extra.

(2) "The Study of Trees in Our Primary Schools," for 12 cents, or by mail 8 cents extra.

In ease a large number are wanted, as for schools, etc., they can be forwarded by express.

These publications are neatly gotten up, and, as they are in great demand (the first edition of 5,000 being exhausted in ten days), charging for them at cost is the only feasible method of dissemination.

I am sorry to have kept you waiting, but pleased to say I am able to supply you or your friends with as many as you may care for, as the new edition has just been received.

Very truly yours,

F. W. RANe,

State Forester.

State House, Boston, Mass. 


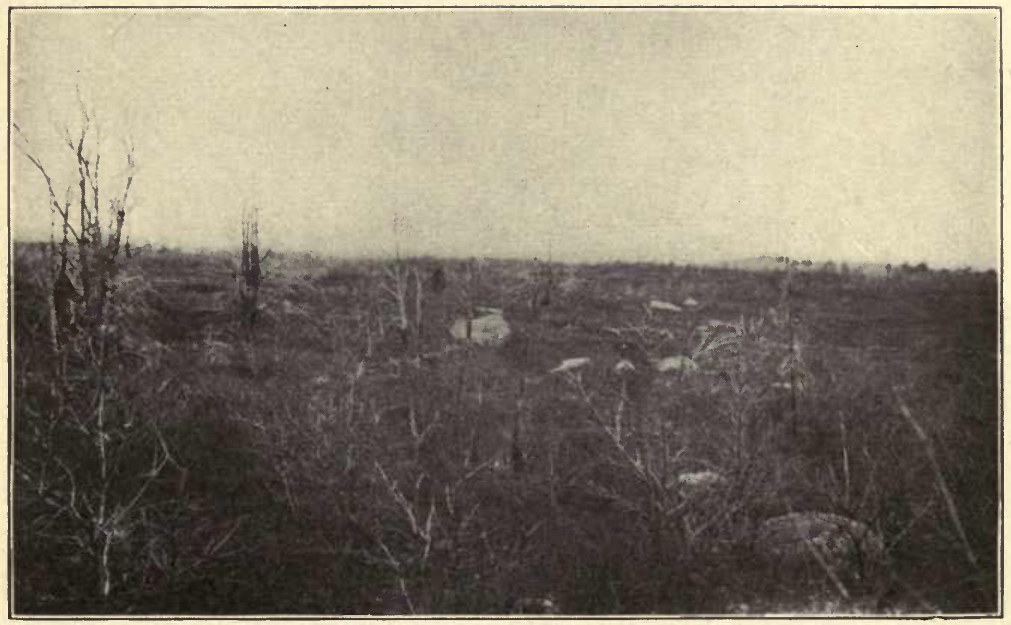

MassaChusetts FOREST LAND. - Reduced to desert conditions by repeated fires; remedy, stop possibilities of fires and replant. 

Examination of Woodlands, and Practical Assistance GIVEN OWNers.

The policy of this office in giving assistance to owners of woodland in this State has been continued during the past year, with very satisfactory results. This assistance consists in an examination and report to the owner on the condition of his woodland or potential woodland, and advice looking to the treatment of the same. This advice, other than travelling expenses, is given free to the land owner.

The examinations made in 1908 number 64, outstripping the record of all previous years. The highest previous mark was 47 in 1906 , while last year they numbered 37 , - an increase of 67 per cent. The acreage is $15,842,-$ an increase of 86 per cent over that of last year.

Four of these examinations were what are called working plans; that is, the land was surveyed, and a forest map accompanied the report. The written outline included an estimate of the amount of standing timber, its value, the improvement work advised, its cost and the probable results. Two of these were made for private parties, one on a tract of 250 acres and one on a tract of 400 acres. The chef-d'ceuvre of the year was a forest working plan for the city of Fall River, which covered the watershed of North Watuppa Pond, the city's water supply, - an area of more than 5,000 acres. The city owns 3,000 acres of this land. The fourth working plan is for the town of Westfield, and covers the watershed of their supply in Granville, some 6 square miles. Only the field work of this plan has so far been completed.

These working plans made on the watersheds are not alone useful to the communities for which they are made, showing them how they can handle the lands in their possession to the best advantage, but offer a basis for the study of the effect of forests on water flow. The working plan gives the character of the watershed, its area and the amount of forested and nonforested land. The controlling boards are usually in possession of figures which give the yield of the ponds and streams which constitute the supply. After a 
number of watersheds of different character have been studied, some useful comparisons can be made from the accumulated data, and perhaps light thrown on a subject which has not been studied to the extent that one of such importance should be in this country.

A certain amount of "booming" was given to this phase of the work by sending out circular letters to the various State institutions, 15 in all; 5 of these took advantage of the offer and sought advice in regard to their woodland. Circular letters were also sent to the water supply authorities in the various cities and towns, and 5 have asked for examinations; other boards have asked for assistance.

\section{Results of Assistance for $190 \%$.}

Blanks were sent to 25 people who received examinations last year, the object of which was to find out how far the recommendations made were carried out. Concerning the other 12 of the 37 the office was in possession of information which made the sending of blanks unnecessary. It was hoped also that this sign of interest in the work of last year would stir up those that have done nothing.

A summary of the results of this investigation is as follows: out of 37 examinations, 17 were recommended to thin. 20 to plant, 3 to do nothing, and 4 have no cards on file. Of those recommended to thin, 3 did all the work and 6 did part of it; this leaves 8 who have done nothing, or have not reported, which we imagine is much the same thing. On the planting side, 2 carried out all the work as advised, and 10 did something; the remaining 8 did nothing, or have not reported.

From the results of the work as reported for previous years, and from experience gained during the past year, we come to the following conclusions:-

1. That planting excites more interest and is more readily taken up than thinning.

2. That thinnings are increasingly important, as the work of fighting the gypsy moth becomes more widespread.

3. That thinning work is much more likely to be carried 
out if the trees to be cut or left are marked by the visiting forester.

4. That elaborate working plans and maps, when made for private parties, result in nothing more being done than would come from an ordinary examination and report, and so should be abolished except in certain cases, when they should be made at the expense of the owner.

5. That, if this co-operative work increases during the present year at a rate approaching that of the last, it will be impossible for one man to accomplish it, so that another technical forester to help in this and other work will be a necessity in the office.

\section{The New Application Blank for Examinations.}

In order to simplify matters, and thereby get a larger number of our people owning woodlands acquainted with the willingness on the part of the State to assist them, the following new blank was printed and distributed very generously:-

No........

Received................

Application for an Examination of Forest Lands to the MassaChusetts State Forester, State House, Boston.

The State Forester stands ready at all times to promote the perpetuation, extension and proper management of the forest lands of the Commonwealth, both public and private (1904, chapter 409 , section 2).

If you have such lands, and desire an examination of them and advice as to their management, fill out the following blank form and send it to the above address of State Forester.

Upon receipt, this request will be placed on file, and you will be informed, in order of application, approximately when the examination can be made, and a mutual date ean then be decided upon.

The only expense the applicant promises to pay is that of travel and subsistence of the State Forester or his assistants, incurred in making the examination.

It is always more satisfactory to personally meet on the property the owner or party most interested, at least when the preliminary examination is made. In this way a definite understanding can be had as to future undertakings, and whether working plans are necessary. Often a preliminary visit to gain knowledge of the problem and give advice on the grounds are all the services needed. 
When sending this application in, a brief description of the land will assist us.

With the above understanding, I desire to have an examination made of a tract of land of approximately.............eres, located in the town of .............., county of............. State of Massachusetts.

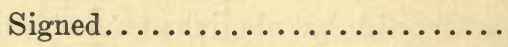

Address.....................

Date................., 19

In order to emphasize the willingness on the part of the State Forester to co-operate with all State institutions in doing forestry work on any land that might belong to them, the following letter was addressed to the superintendents or officials, as the case might be, and a copy of the application enclosed:

My Dear Sir: - I desire to call your attention to one of the duties of the State Forester, that is, the examination of lands belonging to any citizen or institution in the State, and the giving of professional advice in regard to its treatment for forestry purposes. There is no charge to the recipient of this advice except the necessary expense of travel and subsistence. This offer applies equally to land now under tree growth or unimproved land that should be.

A great many citizens have availed themselves of this offer, but very few institutions have made any applications for assistance under this law. It is more than probable that you know nothing of this opportunity, and it is for the purpose of acquainting you with it that this letter is sent.

Public institutions which have theoretically at least a permanent existence, are in a better position than private persons to carry on work which requires several years to show results. The State has established this office to bring about improvement of the present wooded area and the reforestation of unproductive land. It should lead the way by earrying out work on its own property.

If your institution has under its charge any wooded or unimproved land, I hope that you will make application to this office for a preliminary examination, after which, if the area is large and the work complex, a complete working plan ean be made.

We are very busy at the present time, and cannot take up this work immediately, but if we have it in mind, will be in a position to take it up as rapidly as possible.

Very truly yours,

F. W. RANE, State Forester. 


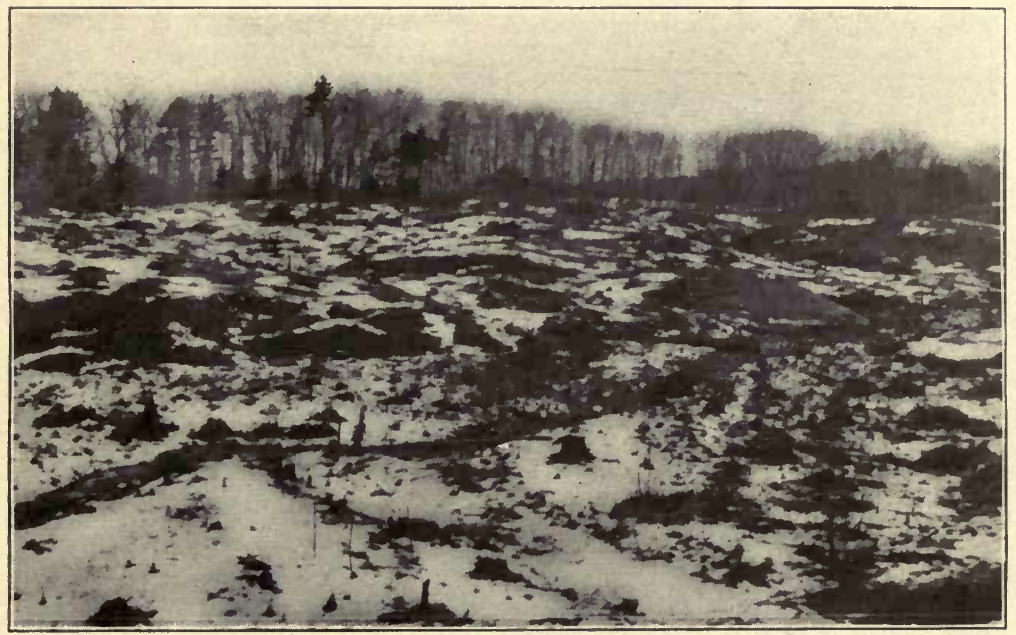

The Sawdust Pile tells the Story. - This land should be immediately planted to white pine. 



\section{Forest Nursery.}

The State forest nursery at Amherst on the farm of the Agricultural College was somewhat enlarged last spring, and, although it has been a very dry season and we had no facilities for watering the beds, they have come through in good shape. We have a stand of white pine, one-year-old seedlings, that is estimated will give over a million trees for future use. Smaller stands of other species of evergreens and deciduous trees are also growing here. This work is self-supporting, and in no instance have trees or seeds been given away.

As in the case of last year, particular pains were again taken this year to assist all persons having had planting examinations made, so that practical results would follow. In this way many plantations were made that otherwise would have remained unplanted.

It is believed that the State can well afford to do even more in nursery work. Commercial nurseries are asking higher prices, and as the demands are constantly increasing and we shall need larger supplies in the future, there can be no mistake in our growing enough to partly supply this demand. When commercial forest nurseries have been in existence long enough, so that we can depend upon getting stock at practical planting prices, we shall not need to do as much. There is a great difference in being able to save from $\$ 1$ to $\$ 3$ an acre in the first cost of planting, when seedlings are uised. When transplants are used, the price is relatively higher.

The following orders were sent out last spring from Amherst :- 


\begin{tabular}{|c|c|c|c|c|c|c|c|c|}
\hline Name. & & & Address. & & & $\begin{array}{l}\text { Quantity } \\
\text { of White } \\
\text { Pine. }\end{array}$ & $\begin{array}{l}\text { Quantity } \\
\text { of Ash. }\end{array}$ & Amount. \\
\hline Prof. J. Tyler, . & - & . & Amherst, & . & & 1,000 & - & $\$ 400$ \\
\hline John A. Cox, . & • & . & East Brewster, & & & 1,000 & - & 400 \\
\hline Wm. W. Colton, & & . & Dalton, . & . & & 2,000 & - & 800 \\
\hline Overseers of the poor & & . & Palmer, . & . & & 1,000 & - & 400 \\
\hline N. D. Bill, & . & . & Springfield, & . & & - & 10,000 & 4500 \\
\hline C. H. Thayer, . & & . & Hadley, & . & & 1,000 & - & 400 \\
\hline Paul C. Rockwood, . & & . & Ashburnham, . & & & 2,000 & - & $8 \cdot 00$ \\
\hline G. P. Morse, . & & . & West Wareham & & & 1,000 & - & 400 \\
\hline G. W. Wheelwright, . & & . & Wheelwright, . & & & 5,000 & - & 2000 \\
\hline C. L. Hutchins, & & . & Concord, & . & & 5,000 & - & 2000 \\
\hline C. A. Codman, & & . & Dedham, & . & & 10,000 & - & 4000 \\
\hline Mrs. L. P. Howe, & . & . & Boston, . & . & & 1,000 & - & 400 . \\
\hline Lawrence Minot, & • & . & Wareham, & . & & 4,000 & - & 1600 \\
\hline G. W. Cook, & & . & Barre, . & . & & 3,000 & - & 1200 \\
\hline G. D. Johnson, & • & . & Andover, & . & & 1,500 & - & 600 \\
\hline E. A. Bowen, . & . & . & Lakeville, & . & & 5,000 & - & 2000 \\
\hline Dr. J. E. Briggs, & & . & Segregansett, . & . & & 2,000 & - & 800 \\
\hline R. E. Allen, . & & . & Shrewsbury, . & . & & 1,000 & - & 400 \\
\hline Kennan Damon, & & . & Concord, & . & & 7,000 & - & 2800 \\
\hline H. S. Cheney, . & & . & Southbridge, . & . & • & 5,000 & - & 2000 \\
\hline A. G. Brockwalter, . & & . & North Wilming & gton, & & 1,000 & 250 & 500 \\
\hline H. M. Killam, . & & . & Georgetown, . & . & & 1,000 & - & 400 \\
\hline E. C. Parker \& Co., . & & . & West Acton, . & - & & 5,000 & - & 2000 \\
\hline L. C. Patterson, ' & & . & Webster, & - & & 5,000 & - & 2000 \\
\hline F. S. Clark, : & - & . & Pittsfield, . & . & & 200 & 200 & 165 \\
\hline A. F. White, & & . & East Freetown & & & 1,000 & - & 400 \\
\hline S. I. Bailey, & & . & Hanover, & . & & 1,000 & - & 400 \\
\hline B. S. Blake, . & & . & Auburndale, & - & & 2,000 & - & 800 \\
\hline Taunton Water Work & & . & Taunton, & . & & 4,000 & - & 1600 \\
\hline P. R. Bradbury, & & . & Norwell, & . & & 2,000 & - & 800 \\
\hline E. A. Hall, & & . & Cambridge, & . & & 2,000 & - & 800 \\
\hline W. P. Bailey, . & & . & Wareham, & - & • & 5,000 & - & 2000 \\
\hline G. F. Kenney, . & & . & Brimfield, & . & & 1,000 & 500 & 625 \\
\hline E. P. Sherburne, & & . & Roxbury, & - & & -1 & - & 100 \\
\hline A. C. Spafford, & & . & Bradford, & . & * & 1,000 & - & 400 \\
\hline Lawrence Park, & & . & Groton, . & . & & 1,000 & - & 400 \\
\hline Sanborn G. Tenney, & & . & Williamstown, & & & 1,000 & - & 400 \\
\hline E. P. Williams, & & . & Buckland, & . & • & 1,000 & - & 400 \\
\hline
\end{tabular}




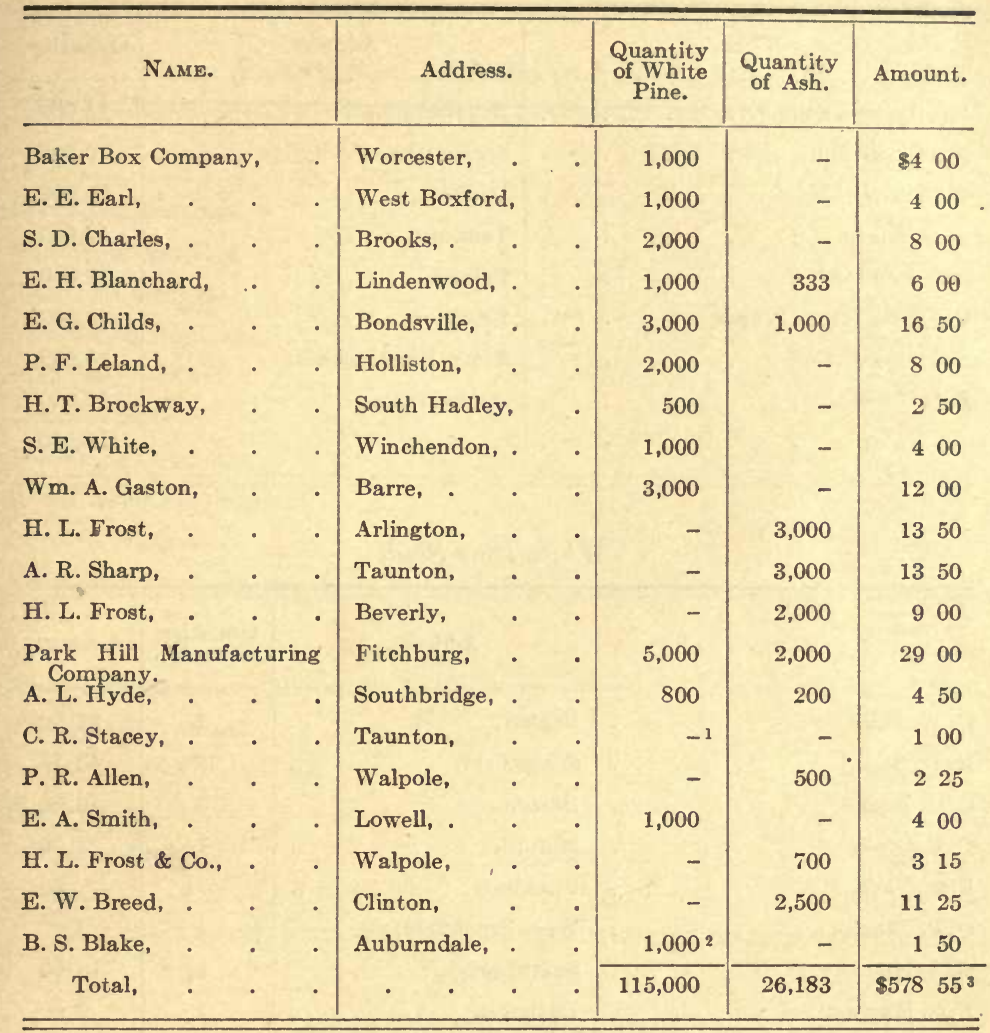

1 School order.

2 Wild seedlings.

3 This amount was turned over to the State Treasurer.

The following larger orders, for purchasers for whom examinations and recommendations for planting were made, were shipped direct from commercial nurseries:- 


\begin{tabular}{|c|c|c|c|c|c|c|c|c|}
\hline \multicolumn{4}{|l|}{ NAME. } & \multicolumn{4}{|c|}{ Address. } & \multirow{2}{*}{$\frac{\text { Quantity. }}{85,000}$} \\
\hline Mt. Hermon School, . & - & - & - & Mt. Hermon, & - & • & - & \\
\hline Nathan D. Bill, & - & - & - & Springfield, & - & - & - & 20,000 \\
\hline Wm. G. Nickerson, & . & - & - & Dedham, & - & • & - & 20,000 \\
\hline A. R. Sharp, & - & - & - & Taunton, & - & & - & 50,000 \\
\hline Everett Flood, . & - & - & - & Palmer, & . & & - & 10,000 \\
\hline Brockton Water Works, & - & - & - & Brockton, & - & & - & 30,000 \\
\hline N. I. Bowditch, & - & - & - & South Framin & & & - & 10,000 \\
\hline P. M. Low, & - & - & . & Baldwinville, & - & $\cdot$ & - & 10,000 \\
\hline Total, & . & - & - & - & - & • & - & 235,000 \\
\hline
\end{tabular}

White Pine Seed.

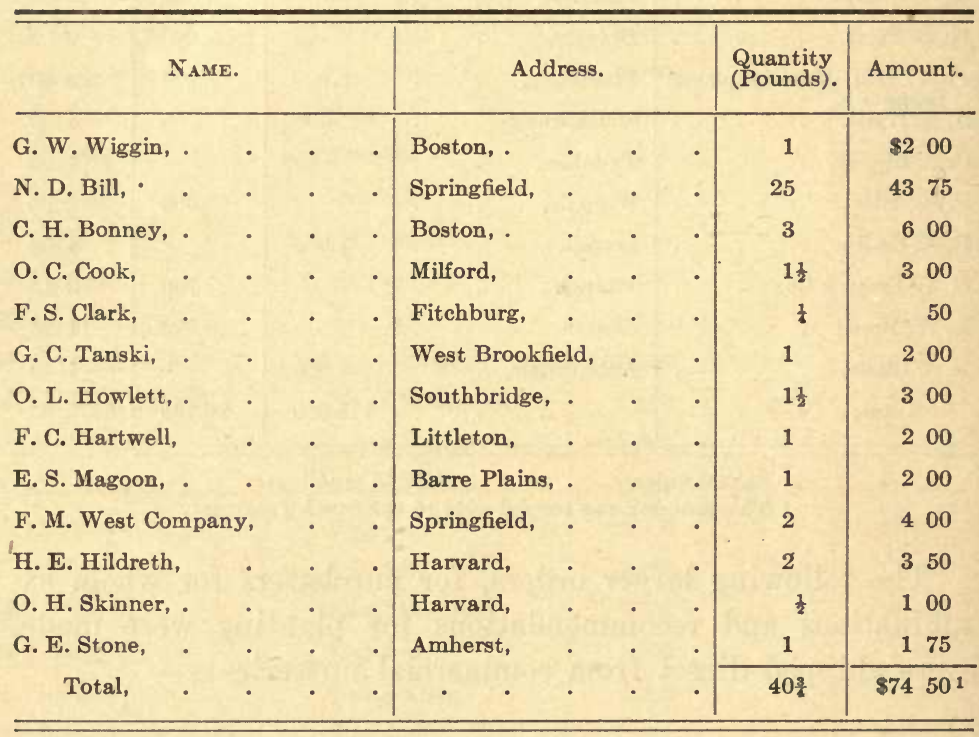

1 This amount was turned over to the State Treasurer.

As stated in last year's report, it has been our purpose to see that all persons for whom examinations are made should be assisted directly in getting practical results. One way in which we served to accomplish this last spring was to furnish the seedlings at cost, and what we were unable to furnish from the State nursery were purchased and sent to them. 
Nursery Stock on Hand in Fall of 1908.

\begin{tabular}{|c|c|c|c|c|c|c|c|c|}
\hline \multicolumn{7}{|c|}{ VARIETY. } & Age (Years). & \multirow{2}{*}{$\frac{\text { Quantity. }}{150,000}$} \\
\hline White pine seedling & . & . & . & . & . & . & 2 & \\
\hline White pine seedlin & . & . & . & . & . & . & 1 & $1,200,000$ \\
\hline Pitch pine seedling & . & - & . & . & . & . & 1 & 40,000 \\
\hline Norway pine seedli & , . & . & . & . & . & . & 2 & 25,000 \\
\hline White ash seedling & . & . & . & . & . & . & 1 & 20,000 \\
\hline Chestnut seedlings, & . & . & . & . & . & . & 1 & 5,000 \\
\hline Black locust seedlir & . & . & . & . & . & . & 1 & 10,000 \\
\hline Honey locust seedl & s, . & . & . & . & . & . & 1 & 12,000 \\
\hline Boxelder seedlings, & . & . & . & - & . & . & 1 & 30,000 \\
\hline \multirow{2}{*}{\multicolumn{2}{|c|}{ Horse chestnut seedlings, }} & & \multirow[t]{2}{*}{. } & \multirow[t]{2}{*}{. } & \multirow[t]{2}{*}{. } & \multirow[t]{2}{*}{. } & \multirow[t]{2}{*}{1} & 100 \\
\hline & & & & & & & & $1,492,100$ \\
\hline White pine transpl & s, . & . & . & . & . & . & 3 & 40,000 \\
\hline White ash transpla & - & . & - & - & . & . & 3 & 500 \\
\hline Catalpa speciosa tr & plants, & . & . & . & - & . & 2 & 1,000 \\
\hline Maple transplants, & - & - & - & - & - & - & 2 & 1,000 \\
\hline Oak transplants, & . & - & - & . & - & . & 2 & 500 \\
\hline Total, . & . & . & . & - & . & $\cdot$ & . & $1,535,100$ \\
\hline
\end{tabular}

Seed on Hand in Fall of 1908.

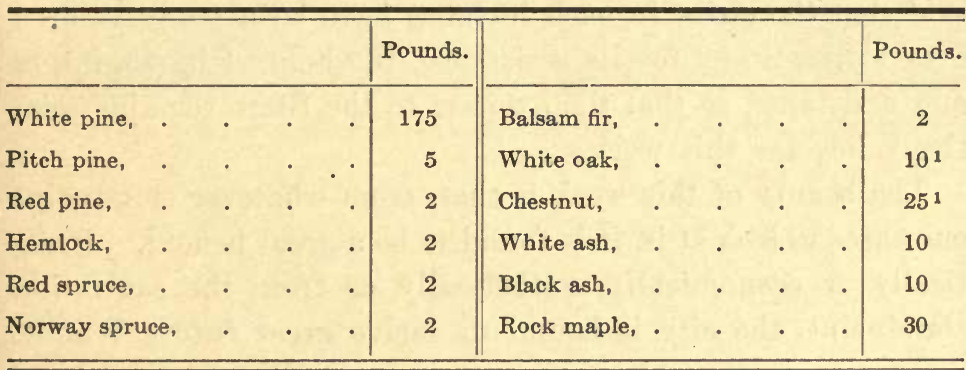

1 Bushels.

Municipal Forests.

One of the interesting features of the year was the spontaneous development of an important field of endeavor in forestry undertakings that has come in for a large share of the time of the State Forester's office. 
Just at a time when we were planning and hoping for the establishment of more permanent forest reserves, Mayor Coughlin of Fall River, together with his water commissioner and city engineer, called at the office in an official capacity to determine if the State could assist them in converting their water basin about Watuppa Pond into a forest, the suggestion having come to the water commissioner when reading an article which appeared in one of the Boston Sunday papers, on the State Forester's work. The results of this meeting were that the State Forester and his assistant spent a day with the Fall River city officials, made a preliminary report, which was accepted, and then a working plan of the whole watershed, which covers an area of over 3,000 acres, exclusive of the reservoir itself. This work will appear as a publication from this offce later in the year.

Upon learning of the work at Fall River the town of Westfield applied for a similar examination and plans for its watershed. This report is in progress at the present time.

Seeing that the work would be of equal interest to many other cities and towns, the State Forester wrote all such, with the result that at the present time we have applications on hand for several more, and this department of the office can see plenty of work ahead of it for some time. It may be said that the cities in each instance have been ready to turn over to the State, for its assistance, the help of its engineers and assistants, so that the expense to the State remains relatively low for this work.

The beauty of this work is that, from whatever standpoint one cares to look at it, it is found to be a great benefit. Practically or economically, æsthetically or from the sanitation standpoint, the city is bound to derive great future benefit.

\section{Public Lectures and Addresses.}

The State Forester has done all this kind of work he possibly could, and keep up with the routine work necessary under the present organization. During the winter months one's whole time could be utilized largely in lecture work on forestry, the demands are so great. As heretofore, the policy has been to accept invitations to address public meetings 


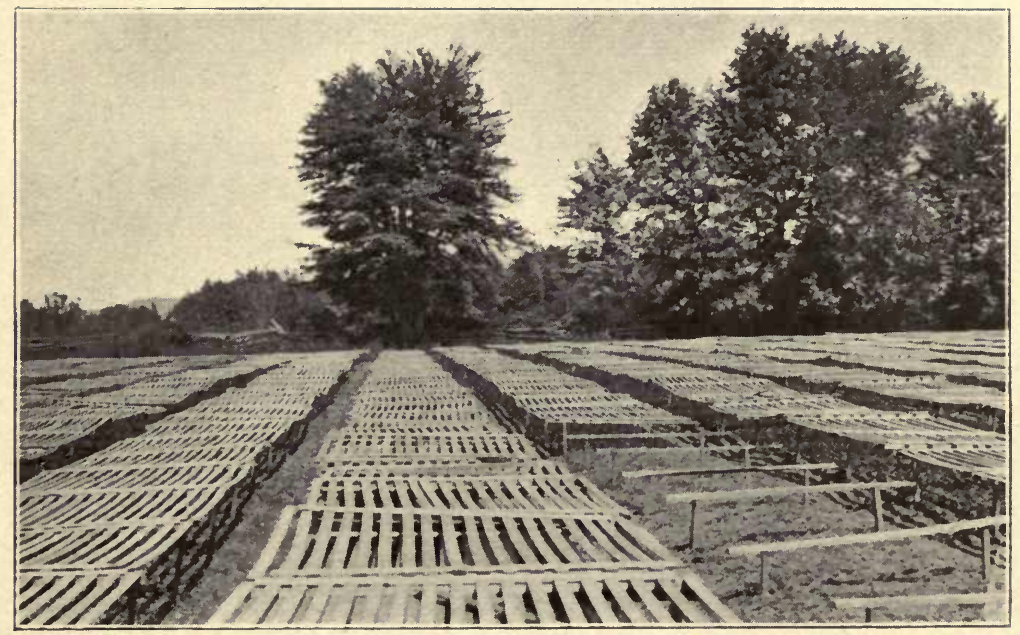

State Forest Nursery AT Amerst. - Over 1,000,000 white pine seedlings at end of first year. 

whenever it can be shown that good results are likely to follow. In accepting invitations, the request is made that an audience of at least 100 be guaranteed, if possible.

\section{Lectures before Business Men's Organizations.}

One of the pleasing features of the year was the great interest manifested in forestry by our various boards of trade, merchants' associations, lumbermen's organizations, etc. The State Forester delivered talks on forestry before such organizations in the cities and towns of Fitchburg, Pittsfield, North Adams, Springfield, Winchendon, Bridgewater, Upton, Clinton, and several in Boston, as the Massachusetts Reform and Economic clubs, Lumbermen's and Market Gardeners' associations. Results of these meetings have been very apparent in the great amount of inquiries and requests that have come to the office from this source. It takes business men to do things, and to these organizations the State Forester looks for very much assistance in the future.

\section{Lectures outside the State.}

The State Forester has been called upon to address various organizations during the year outside the State, some of which were: the Society for the Protection of New Hampshire Forests, at Intervale, N. H. ; the Citizens of St. Johnsbury, Vt.; the Society for the Promotion of Agricultural Science, at Washington, D. C.; the American Forestry Association, Washington, D. C.; and the University of Maine, at Orono, Me.

The National and State Conservation Commissions.

The State Forester was chairman of the State delegation appointed by Governor Guild to attend the Conference of Governors, called together by President Roosevelt last May. Later the same committee of three was appointed as the State Conservation Commission, to assist the National Conservation Commission in getting together data relative to the natural resources of the nation. Of course the office of the Massachusetts commission was in collecting Massachusetts data only. This same State commission, headed by Governor 
Guild, attended the second meeting of the National Conservation Commission in Washington, D. C., during the week of December 8.

\section{The National Irrigation and Forestry Congress.}

The State Forester was invited to address the above congress at Albuquerque, N. M., September 29 to October 4, on "Municipal Corporation and Private Ownership Forestry Development."

This congress was as usual a very representative occasion, and offered a splendid opportunity to meet men who are doing things. To the acquaintances made at this meeting and that of last year at Sacramento, Cal., are due the interest and courteous treatment given us by western men at the recent hearing before the agricultural committee of Congress at Washington, D. C., the fore part of this month, at which Governor Guild presided. Governor Chamberlain of Oregon, Ex-Governor Pardee of California and President-elect Barstow of the National Irrigation and Forestry Congress, who were in attendance at the Conference on the Conservation of Natural Resources at the time, all prominent in said Irrigation and Forestry Congress, gladly appeared and endorsed our movement for the White Mountain and Southern Appalachian forest reserves.

As alluded to last year, the more one sees of the more arid sections of the west, the better satisfied he is with the future possibilities of New England forestry.

\section{Meeting with the State Firemen's Associations.}

One of the pleasing occurrences of the year was the opportunity offered through an invitation of the State Firemen's Association to address that body on "Forest Fires and their Prevention," at their annual meeting which convened at Nantucket on September 9 and 10. Not only was the State Forester well received and given an exceptional opportunity to get acquainted with the men who have in charge the great responsibilities of protecting our homes in our cities and towns, but he was able to discuss with these men the impor- 
tance of also systematizing and working out similar methods for handling forest fires.

Since attending this meeting and making the acquaintance of so many good men, a great many valuable suggestions and assistance have come to the office; and there is little doubt but that as time goes on very valuable assistance is bound to come from the chiefs of fire departments in regulating and organizing forest-fire fighting methods for effective results.

Our forest wardens and the chiefs of fire departments and their deputies should by all means work together in harmony. Already in many instances both offices are held by one man. Where the offices are separate, a definite understanding and methods of co-operation should be entered into. Both are public servants, and should be public spirited and work together for the benefit of all.

\section{Pine Tree Blight.}

There probably have been few subjects that have caused more alarm than the so-called pine tree blight, which was so prevalent last year, and is still in evidence, although to a far less degree, this season. As was predicted in last year's report, the trouble was not as prevalent this year, especially in sections where it was very bad last year, as at Winchendon. However, at Greenfield it was worse, if anything. On the whole, for the State, while trees affected last year still showed the effects, and an experienced person could pick them out at a distance, nevertheless they have improved in condition, and many will undoubtedly outgrow this malady.

In order to keep in close touch with the pine tree blight, so that, should it develop still further this season, we might possibly obtain further information for combating it, besides having the assistants and others on the alert for developments, a young man, Mr. Thomas Jones, a recent graduate of the Massachusetts Agricultural College, who had specialized in mycology, was employed for a month. Nothing particularly new was found, other than was reported in the annual report last year.

Early in the season most of the tip growth of the new shoots seemed to be affected, and it was thought that some 
young plantations of trees from three to six feet high at Winchendon were more troubled than last year; but a month later it was found that the browning or dying did not extend beyond the first stage, and when the needles were fully out the general appearance was little else than normal.

Undoubtedly more or less white pine trees will be affected from year to year with this trouble; but it is believed that we need to pay little attention to it, other than when a tree is badly affected and is going to die, it should be cut and utilized. The greatest loss comes where pine trees are valued from the æsthetic or landscape-gardening standpoint; and these are not as likely to be troubled, as the chances are they are on better soils, and hence likely to withstand such depredations.

Forest Fires.

The past season has been a noted one throughout the country for disastrous forest fires. The extremely dry season rendered conditions exceptionally favorable for fires throughout the whole summer season. Exceptionally heavy forest fire losses were reported constantly from all the New England States, New York, Canada and the Lake States.

This is the first year Massachusetts has ever had a definite system whereby reliable data on forest fires have been collected. We are not in a position, therefore, to compare this year's data with those of previous seasons, other than in a general way. The State Forester takes pride, however, in reporting that it is his belief that Massachusetts has suffered relatively less than other States, considering her dense population and previous experiences. When Maine and the Adirondacks and other New England States were having their worst fires, Massachusetts was comparatively free.

It is believed that our new forest warden system saved to the State this year alone far more than people begin to realize. The State Forester has kept one man busy throughout the year, simply attending to the new forest fire regulations and assisting the forest wardens.

During the first part of the season forest warden badges were decided upon, which are numbered consecutively from 1 to 350 , and sent out to all wardens. This has assisted, 


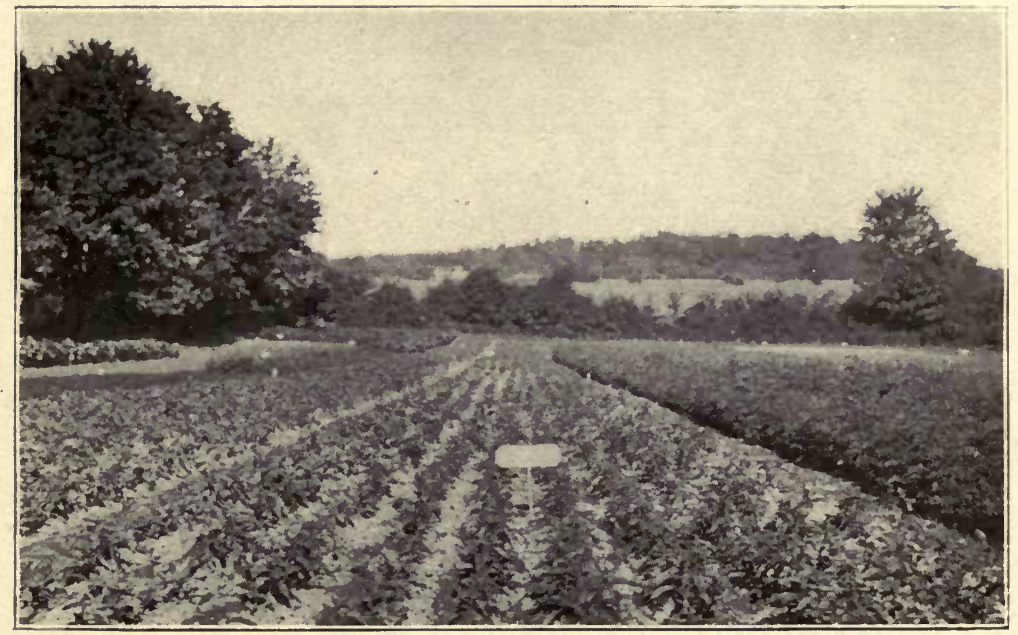

Portion of State Forest Nursery at A Mherst. - Showing transplant beds. 

in that it gives the warden his proper credentials. The number of each badge is kept on file in this office, and thereby any forest warden can be identified. The badges are the property of the State Forester, and held by the wardens only during their services as such.

As alluded to elsewhere, warning forest-fire notices, made of cloth, were supplied to all wardens in large numbers; and they and their deputies took great pains in seeing that these were posted generally throughout the towns, and particularly where there was slash remaining from cut-over lands, etc.

During the very smoky times this office was repeatedly informed from the various wardens that they were exerting themselves and keeping close watch, and even patrolling the towns to minimize the great chances for fire outbreaks. No one could expect a greater loyalty and interest than these newly appointed forest wardens and their deputies have shown, and the State Forester desires here to publicly acknowledge their true worth and fidelity to the State.

It is proposed to publish the data collected on forest fires for the State in a bulletin by itself, a little later on. The following table will be of interest, in showing to what extent and number and of how great damage these fires have been during the year. It may be said also that these fire estimates may be considered extremely conservative. Can any one doubt the needed rational legislation for handling such a parasite upon our veritable future prosperity? 


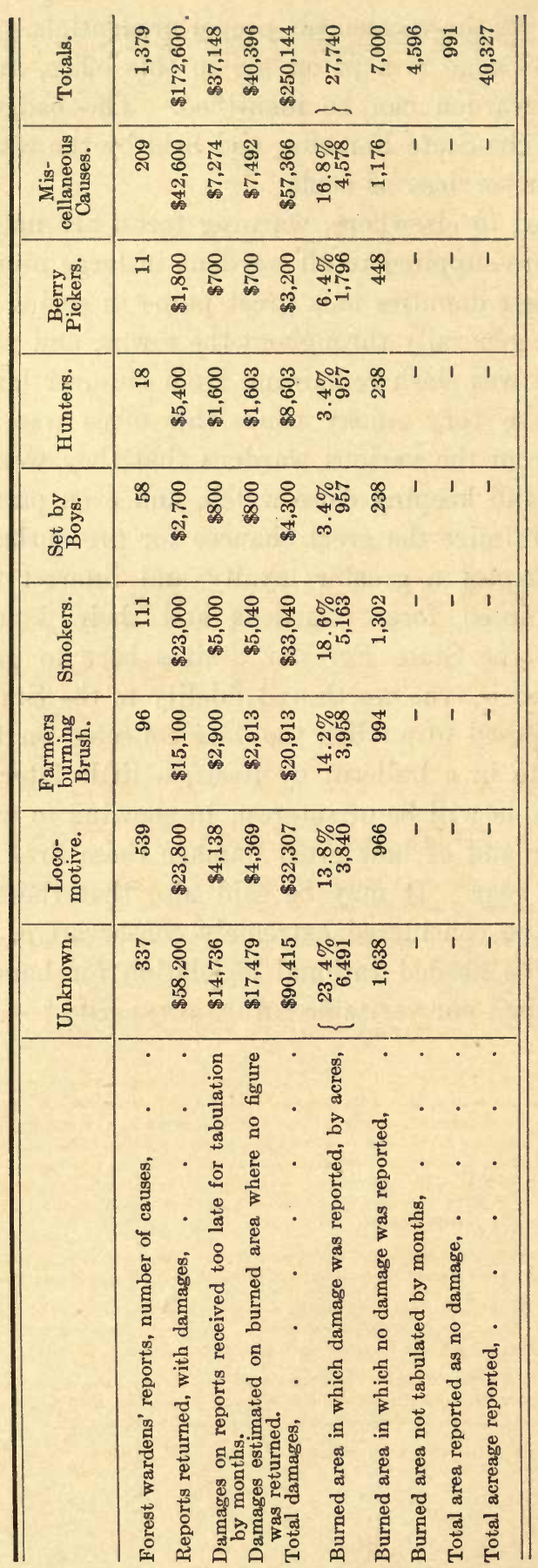




\section{Forest Fire Posters.}

Following the instructions in the statutes, as last year, the State Forester had the abbreviated instructions of the forest fire laws printed on a large paper poster in red and black ink, 18 by 27 inches in size, and distributed them to all railroad stations, post-offices, chairmen of the boards of selectmen and forest wardens. For general use a new, smaller and more practical cloth poster was sent out in large quantities to all forest wardens for use throughout the State. This poster has served its purpose well, and good reports come from every section, which shows our people are taking an interest in stopping forest fires. (See below.)

\section{WARNING!}

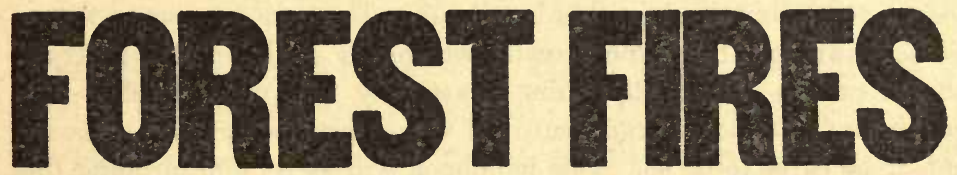

\section{EXTRACTS FROM MASSACHUSETTS FOREST LAWS.}

Setting Fire to Crowing Wood or Timber of Another. Punienable by a nne of not more than sioe.00 or by Impricenment for not more than eix montre. R. L 208, 806 ?

2. Letting Fire Escape. Negligently allowing fire to escape from your own tand to adjolning land. Pumlehable by a fine of not more than s250.00, alse llable for damages. R. L. 208, sects 8 and 9.

3. Forest Wardens Not Liable to Arrest for Trespass. Wardens, Deputios and Aseisto ants, not liable for trespase while ecting in the reasonable performance of their duties. Acts 1907, 478. Sec. 6.

4. Permit to Light Fire in the Open. In Towns so voting. A permit from the Forest Wor. den must be obtained to start a fire between April 1 and December 1. The only exception being - that debris from nolds, gardens and orcharde, or leaves and brush from yarde may be burned on ploughed fields by the owners thereof, their agents or lessees, but in every case such fire shall be at least two hundrod feet distant from any forest or sprout lands, and thall be properly attended untll oxtingulehed. Violation of this provision-Punishable by a fine of not more than 8100.00 or Imprieonment for not more than one month or by both such fine and imprisonment. Note 1908, 209, 800. 1.

5. Arrest without Warrant. The forest wareen may arrest any persons found in the act of cettin's a fire in violation of the provislone of this act. Acte 1908, 209, Soc. 4.

6. Penaity for Refusing Aid. Any persen botween the ages of 18 and 50 years who refuses. without good cause, to assist the Forest Warden or hle deputles in the fighting of forest fires 1. llable to a fine of not lese than 8 or more than 100 dollars. R. L 32, Soc. 21: 1907.478 , Sec. 3

7. Disturbing Notices. Whoever wilfully toars down of destroys any notice posted under the provislens of this act shall be punished by a fine of s10.00. Act 1907. 476, Soc. 7. 
Forest Mensuration of the White Pine in MassachuSETTS.

The above was the title of a publication of this office sent out during the year. The purpose of the publication was set forth in its preface, "Reasons for Publication," as follows:-

This handbook is published by the State Forester that our people in Massachusetts may have at their disposal information as to how they may determine, by simple measurements and the use of tables, the yields, and hence the values, of pine trees, from the commercial or lumberman's standpoint.

The time has come when we should have a better practical working knowledge of forest values. Forest products continue to become more valuable yearly. It is believed that business men and all persons at all interested in forestry matters, as well as lumbermen and farmers, ean get much that is of value from the tables and general information contained in this handbook. There is no reason why a person owning white pine growth, whether a small or a large tract, should not be able to determine practically how much lumber it is capable of producing, and hence its value, even before the trees are eut, if he cares to do so. This handbook will assist him in doing this very thing.

Trees are easy of access, and can be estimated with great accuracy. The old idea, that a man must spend a lifetime as an estimator or cruiser in order to determine accurate yields from tree growth, is rapidly passing. The time of guesswork is being replaced by more definite knowledge.

In order to secure the data contained in the tables, the State Forester has had measurements of white pine taken in all parts of Massachusetts by trained men, and the data have been submitted to practical experts as well, so we feel the work is authoritative.

This publication has been well received and apparently much appreciated.

\section{Good Roads a Benefit to Modern Forestry.}

The forward movement and excellent work being carried out in road construction throughout Massachusetts are bound to result in bringing about modern forestry management in many back rural towns, more quickly than many people realize. The farther the forests are from the railroad or mar- 
ket, the greater the expense made necessary in operating them. If to disadvantage in distance poor roads be added, it is readily seen that the transportation question alone precludes practising modern forestry. The fact that two to three times as large loads ean be drawn on good roads as on poor ones, and in many instances more trips can be made in the same length of time, will convince any practical lumberman or business man of the importance of good highways.

The State Forester is under many obligations to the State Highway Commission for courtesies extended during the year to study the State forestry conditions, by being invited to accompany said commission on their inspection tours, which were made by automobiles.

The Tenth Anniversary of the Biltmore Forestry School.

The State Forester was the Massachusetts delegate appointed by Governor Guild to attend the tenth anniversary of the Biltmore Forestry School.

This occasion, which occurred at Biltmore, N. C., November 26, 27 and 28, on the estate of George W. Vanderbilt proved a most instructive and valuable one. As the "American Lumberman" expressed it, "An Extraordinary Outing of Representatives of all concerned with Timber, from the Tree to the Trade." The three days were extremely well planned by Dr. C. A. Schenck, the head of the Forestry School, for getting just the information desired. There were representative men present from every phase of forestry interests and from all over the country, including Canada.

It was an excellent opportunity to see just what can be accomplished in forestry in a comparatively short time, and also to have pointed out and discussed wherein failures have been made.

This occasion marked a new epoch in American forestry, and, without giving further details about the gathering, suffice it to say that the anniversary proved extremely instructive and valuable, from a great many standpoints. The State Forester felt well repaid for the trip. 
Co-operation with the United States Forest Service and Forestry Offictals of Other States.

The State Forester wishes here to acknowledge the hearty co-operation that Mr. Gifford Pinchot and his able assistants and forestry officials of the various States have rendered whenever called upon. At the present time co-operative work with the division on forest products of the forest service is going forward, which we believe will prove of great value when finished. This will require some little time yet. It has been a pleasure to be of assistance to the many forest service men who have been compiling data of various sorts for the National Conservation Commission reports throughout the season. The State Forester weleomes all interested in forestry.

Articles for Papers on General Forestry InformaTION.

During the year there were calls upon the State Forester for some general literature for use in interesting owners of woodland in a few sections. This call came first from an enterprising newspaper man and a lumberman at Greenfield. Thinking the information would be of equal use to all rural sections, articles were prepared from time to time and sent to all papers that could use them to advantage. These articles were used quite generally, and we believe have been of assistance to many. Four of the articles sent out were as follows: -

How may the Farmer assist in the Reforestation of New ENGLAND.

Forestry, when managed properly, will utilize our millions of acres of land in New England, at present seen on all too many farms scattered in every section, known as waste land, abandoned pastures, sprout lands, barrens, plains, etc., returning them to forest culture.

If modern agriculture has taught us farmers anything, it is that concentration of effort, better culture and modern rotations are what make profitable farms. If an inventory is taken of the average New England farm, it will be found that there are many acres eapable of yielding more profit to the farmer if devoted to the forest or 
tree crop than used for any other purpose. These acres should therefore be converted to forestry as rapidly as possible. If each farmer will act accordingly, it may be only a matter of a comparatively short time when New England would be blessed with wellbalanced rural conditions. The State Forester, agricultural colleges and forestry schools of various New England States are ever ready to assist and advise in forestry work.

The same culture that will return saw logs to our mills, make work for our country folk in winter, replenish our town treasuries, repaint the old red schoolhouse, pay the sexton to again ring the country church bell, make better roads, and, in short, return the former substantial livelihood of country life, will also conserve moisture, protect and enrich the soil, give an equitable climate, and return to New England the natural beauty we all would love so much to see.

This is a seed year for the white pine in Massachusetts, and it may be elsewhere. Let each farmer collect some cones before they open, which is very shortly, then extract the seeds and plant them next spring in a bed in the garden. In two years' time he will have enough seedlings, if they are properly cared for, to set out many acres. We must learn to plant and care for our forest lands in the same way we do our better tillable soils, and they then will bring proportional yields of profit. The beauty of the whole forestry problem of New England is that in its practical solution it not only results in economic forestry, but solves the æsthetic side as well. It is entirely wrong to think that trees should never be cut. Lumbering is as important to suceessful forestry as is the digging of potatoes or the harvesting of any crop when it is ripe. The same essentials of culture, also, must be understood in getting maximum returns in the one case as in the other.

\section{F. W. RANE, Massachusetts State Forester.}

\section{How to collect and use White Pine Seed.}

White pine seeds sell at $\$ 4.50$ retail, $\$ 2$ in large lots, in Boston this summer, and the seeds of some other evergreen trees are still higher. Every owner of woodland with matured pines is in a position to take advantage of these almost fabulous prices, for the time has arrived when the pine cones should be picked. The white pine cones containing the seeds are ripe, and should be picked at once. This dry weather will open the cones before many days, and the seeds will drop out and scatter to the four winds, almost a total loss, while prudent lumbermen all over the country are paying high prices for seeds picked elsewhere. The market has to be supplied; it fixes a price that will produce the goods. If the seeds cannot be obtained at $\$ 4.50$ per pound, they will go higher, until the farmers go into the business of seed picking or give away their prospects to 
commercial pickers. Moreover, the revival of interest in forestry is so marked in Massachusetts this year that it points to reforestation on a broad seale in the near future, and this will be attended by an increasing demand for the white pine seed. Tree owners who are alive to their prospects will prepare for this demand by saving this year's erop, since the white pine seed will retain its vitality for several years, if given normal conditions, - not too moist or excessively dry.

There is no time to lose this year, nor time to make elaborate preparation for systematic picking. Collect the seeds somehow, by the means that first suggest themselves, and the market will turn them into cash. One way is to run a long ladder up the tree; another is to go into the sections where lumbering is going on, and collect the cones as the trees are felled. Boys may elimb up with small bags thrown over their shoulders and pick from the large branches without difficulty, about the same as apples are picked. After the cones are gathered, they may be dried where squirrels and mice are kept from them, and then thrashed until the seeds fall out. The practice of using a bag to put cones in is convenient, as they may be flailed in the bag during spare moments, and the seeds fall out where they are readily separated from the waste.

To turn this waste crop into ready cash is not the only inducement in store for the land owner. It makes reforestation so comparatively inexpensive, producing the seed at the cost of cheap labor, instead of at $\$ 4.50$ per pound, that there no longer will then be good reason for allowing waste land to remain idle and non-productive. Under its new policy the State of Massachusetts gives direct aid and counsel to any land owner who desires to seed his waste land. Communication on this subject may be established with the Massachusetts State Forester, Prof. F. W. Rane, State House, Boston, and he will be pleased to meet the farmers and to give practical advice. He says that of the vast amount of lumber used in Massachusetts probably 95 per cent. is imported from other New England States, from the west and from the south. Massachusetts certainly is capable of growing more than 5 per cent. of the lumber it uses; in fact, it is destined to become a lumber State that will closely approximate its consumption with its production, and the production of a seed erop at reasonable cost is the first important step in this morement.

\section{An Opportunity to Reforest Waste LaNds.}

Reforestation is so vital to Massachusetts and to her country population that it will be placed on a systematic basis in the near future. Preparations are now being made, under authority of an act of the Legislature of 1908 , appropriating $\$ 5,000$ for this year and $\$ 10,000$ annually thereafter. With this money the State proposes to buy and reforest idle land, and has already addressed itself on the subject 


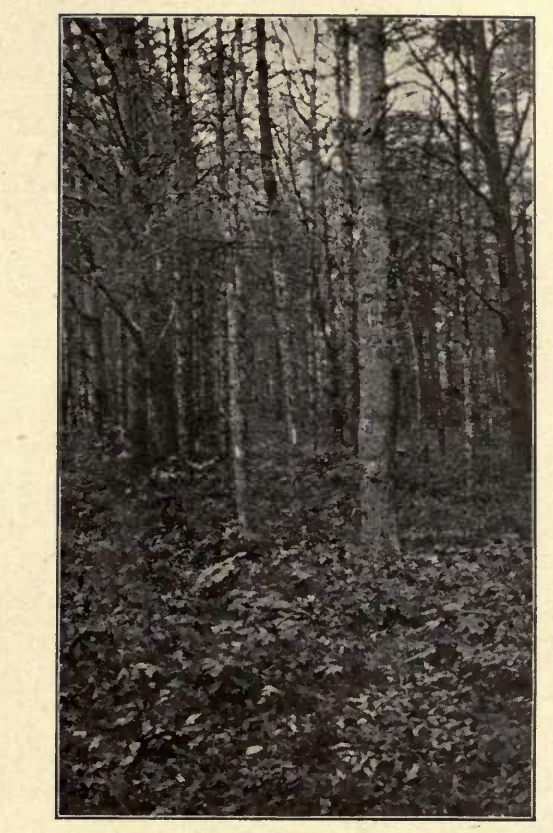

A Pine Stand at Plymouth marked FOR THINNING.

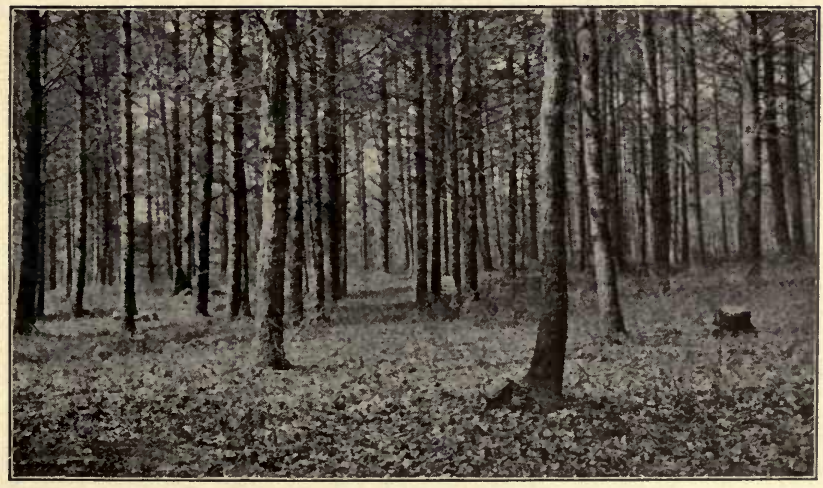

The Same Stand after Thinning. 

to the selectmen and land owners throughout the Commonwealth, with most promising results.

The proposition is arousing attention everywhere. Hundreds of acres of waste land have been offered to the State at nominal eost, a considerable portion of it being offered as a free gift. Such overtures have come from West Brookfield, Spencer, North Ashburnham, Hubbardston, West Tisbury, Westford, Sharon, Gardner, Oxford, Winchendon and Sandwich. A business concern has pledged itself to donate 100 acres of land in southern Massachusetts, and an individual in Hampshire County has come forward voluntarily with an offer of 300 acres. This movement among land owners to turn over their idle property to the State, brisk at its very inception, substantiates the general supposition that there is in Massachusetts a vast acreage of land that has become unprofitable through indiscriminate and unbusinesslike lumbering. It shows, further, that the owners of this property have lacked the incentive, or the means, or the inducement, to tie up their capital on soil where the returns are so remote. Now comes their opportunity to let public eapital develop their land and restore it to a paying condition on better terms than private effort eould do; and many of them are quick to see that this is a wise policy, even if it takes away conditionally their title to the property. On these terms the State is getting a wide choice of land, and when it has registered enough to permit of proper selection, the actual work will begin. There seems to be no doubt now about the ability of the forest department to get all the land it can handle.

While the deed in these transactions passes the land over to the State, it provides that the original owner may repurchase within a stipulated period, at the price he received plus the money spent on improvement and 4 per cent. interest. In all probability the replanting can be done by the State at less cost than by private effort, because the State has the work reduced to a science, and a corps of trained men to execute it. Not only are individuals accepting this proposition, but townships have taken it under consideration, with a view to turning over to the State sections of poor farms and watersheds for the planting of trees.

Both in accepting free and in buying land, the State will give preference to tracts situated along highways, where the new plantation may serve the dual purpose of restoring the lumber stock and demonstrating to the public how the work should be done.

\section{The Collection and Use of Other Forest Tree Seeds than White Pine.}

Now is the time to collect certain forest tree seeds. One crop of the forest is gone, - the white pine, - and another is ready for the harvest. In years gone by the pine seed has been wasted in Massachusetts; it was wasted this year, too, but it attracted more attention 
than in the past, and the reports from various parts of the State show that more was collected than is usual. For instance, a man in Winchendon has collected 100 pounds of clean seeds this fall, employing boys to pick the eones for him, and he netted at least $\$ 100$ on the job. Massachusetts could be made to supply its own seed for reforestation, and it is squandering a valuable product so long as it does not. The rebuilding of our forests is of such vast importance that it is the first subject to be taken up at the conference of New England Governors soon to be held in Boston. Land owners have an excellent opportunity this fall to provide themselves with the seeds of hardwood trees, such as the white ash, the rock maple, the hickory, the chestnut and the beech tree. The picking should begin at once, and it should be completed before the second week in November.

On the white ash, for example, the leaves have fallen off and the seed remains on the tree; they are about two inches long, and are provided with wings, hence are easily seen and reached. A mediumsized tree, about as large as an ordinary apple tree, may yield about 20 pounds of seed, retailing at about $\$ 1$ per pound. Almost any other crop of equal value would be taken care of, but this one, as a rule, is allowed to go to the winds. It can be harvested into a bag without much difficulty, either by shinning the tree or raising a ladder. There is a good demand for white ash. The seed of the rock maple has about the same commercial value; it is easier to gather, because the limbs on the tree hang low, and it will remain on the tree two or three weeks longer. How to keep the seeds of the white ash and the rock maple over winter is a problem that requires some attention, but it is not difficult. It is only necessary to dig a hole in the ground some feet deep and sink a box into it; in the bottom of the box put a layer of sand, and then spread a layer of seed 5 inches thick; cover this with 2 to 3 inches of coarse sand, and repeat the layers until the box is filled or the supply exhausted. Then cover the box about 1 foot deep, to prevent the eontents from freezing, and the stock will keep until next April, when it should be taken up. Kept thus during the winter it is ready for planting in the spring, and should be set half an inch deep in rows about 1 foot apart. In one year the plants will be large enough to transplant to the forest where they are to remain.

The first substantial frost will open the burrs on the white oak, the chestnut, the hickory and the beech, and the seeds will drop to the ground, where they can be picked without any difficulty. The acorn is worth about $\$ 2$ a bushel, the chestnut 15 cents a quart and the hickory nut $\$ 3$ per bushel. They are layered for the winter in the same way as the white ash and rock maple, and in case of only a small quantity the most serviceable method is to sink a 2 -foot tile into the ground and fill it with layers of sand and nuts, stretching a 
wire netting over the top, to keep the squirrels out. The pitch pine and Norway pine cones will open almost any time, and should be picked at once, before they open, if this year's erop is saved. The Massachusetts State Forester is aiding in every possible way to accomplish results; let us all do our part.

The following very complete and valuable work accomplished by the Metropolitan Water and Sewerage Board in practical forest planting is published in this, the State Forester's report, by permission of said Board, in order that the data may be put into the hands of our people, who will find it of great value in demonstrating definite results:-

\section{Forestry Work in Connection with the Construction of the WACHUSETT RESERVOIR.}

In order to treat comprehensively the work as it has been carried on, it will be found advantageous to divide the subject into five branches, namely: general; nurseries; plantings; improvement thinnings; fire protection.

\section{General.}

The work of reforestation was begun in 1898 by the preparation of two nurseries for the raising from seeds of both coniferous and deciduous seedlings, to be planted on such of the lands owned by this Board as were not already covered with a timber stand of some description.

The first field planting was made in the spring of 1902, when about 175 acres were planted, and since that time plantings varying in size from 50 to 200 acres have been made every spring and fall.

The results obtained have been exceptionally satisfactory as far as the conifers are concerned, there being approximately 90 per cent. of the seedlings planted which have lived.

The deciduous seedlings raised in the nursery have in almost every ease failed completely after being transplanted into the field. This failure was probably due to the character of the soil in the nursery.

Altogether, there have been planted about 1,330 acres with about $1,850,000$ trees, made up of 948,000 conifers and 902,000 hardwoods, of which about 90 per cent., or 853,000 conifers, and 7 per cent., or 63,000 hardwoods, are living at present.

\section{Nurseries.}

There are two nurseries, one on either shore of the reservoir, having an aggregate area of 8 acres.

The one on the north shore, containing 4.3 acres, is used for hardwood or deciduous seedlings, and was originally arable or grass land, 
so that no great amount of preparation was necessary to make this area suitable for nursery purposes.

The one on the south shore, containing 3.7 acres, is used for the raising of coniferous seedlings. This area was originally covered with a white oak and chestnut stand about fifteen years old, so that a large amount of work, consisting of clearing, grubbing, plowing and harrowing was necessary to prepare the area for nursery uses. This work cost about $\$ 200$ per acre.

The nursery work, which consists of preparing the ground, sowing the seed, earing for the seedlings by watering, mulching, screening and weeding the first year, and transplanting, watering, screening and weeding the second and third years, costs $\$ 1.50$ per 1,000 trees for the first year and $\$ 1.60$ per 1,000 trees for each succeeding year.

\section{Plantings.}

The seedlings, having been at least two seasons in transplant rows, are now ready for their final planting into the field. Planting gangs composed of from 25 to 30 men are employed on this work, 4 or 5 of whom are engaged in the nurseries preparing the trees for the field, which work involves taking the trees from the transplant beds, pruning the roots, sorting, counting, puddling and transferring to the field, while the remainder are engaged in the actual planting process. The maximum rate of planting acquired by an experienced gang under ideal conditions was 1,000 trees per man per nine-hour day.

Spring plantings are made immediately after the frost leaves the ground, and fall plantings before it enters.

Previous to the fall planting of 1906 the general type of planting was white pines, spaced 10 by 10 feet, with some hardwood filler, making the trees 5 feet apart each way. The above-mentioned type was abandoned in 1906 because of the almost complete failure of the hardwoods, and solid white pine stands, the trees spaced 6 by 6 feet, have been planted since that time.

In order to have an effectual screen along the forested portions of the shore of the reservoir, which would prevent the foliage from the deciduous trees from being blown into the reservoir, three rows of white pines, spaced 6 feet apart each way, and two rows of arbor vitæ, 2 feet apart, trees 3 feet apart in the rows, have been planted on the back half of the 50-foot reservoir margin. The greater proportion of the arbor vitæ have failed, probably because of having been planted in the field when too young (two or three years old) to endure the severe exposure which prevails along the shores of the reservoir.

\section{Improvement Thinnings.}

Under ideal conditions the trees require no care after having been planted in the field; but experience has shown that in pasture or brush land, where the common gray birch grows naturally, and in 
sprout or scrub land which has been underplanted, it is necessary to thin out and trim up the hardwoods in order to prevent too much shade and the destructive thrashing of the tops of the pines. This process, termed "improvement thinning among planted trees," costs about $\$ 6$ per acre.

In the original timber stands the policy has been to take out the mature, undesirable or weak trees, thereby improving the stand by giving more space and air to the strong, hardy specimens. This class of work costs about $\$ 20$ per acre, but there is a considerable revenue from the wood cut, which in some cases has been sufficient to make the work pay for itself.

\section{Fire Protection.}

Among the greatest dangers to the forests are fires, and in order to prevent their spreading to or from abutting property, and to provide a line of defence on which to fight them, a fire guard 40 feet wide has been cut around the entire outside limit of the marginal lands of the reservoir. There is also a network of forest roads 15 feet wide throughout the reservation, which acts as supplementary fire protection. The brush and weeds are cut from these two protective systems once every year.

A double furrow has been plowed along that portion of the fire guard where there was no stone wall, to check the advance of creeping fires from neighboring property.

On holidays and Sundays, during the dangerous seasons of the year (early spring and late fall), men armed with fire extinguishers patrol the reservation to further protect it from the ravages of forest fires.

Thus far no serious fires have occurred, though several have started which would have caused great damage but for the effectual protection given.

\section{Table of Work accomplished to Jan. 1, 1909.}

Total area of nurseries (acres),

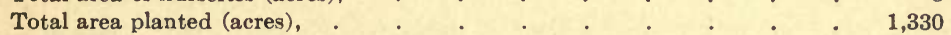

Total number of trees planted: -

Deciduous,

Total length of reservoir margin planted (miles),

Total length of fire guard cleared and maintained (miles), $\quad$. $\quad$ - $\quad 20.8$

Total length of forest roads cleared and maintained (miles), . . . 30

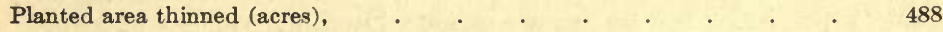

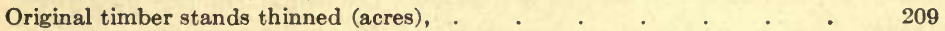

Table of Costs (Wage Rate, $\$ 1.75$ per Eight-hour Day).

Clearing nursery on south shore, $\$ 20000$ per acre.

Maintenance of nursery, first-year seedlings,

150 per 1,000 trees.

Maintenance of nursery, second and third year seedlings,

160 per 1,000 trees per year. 
Planting s: -

Clearing areas preparatory to planting, .

Transplanting seedlings from nursery to field, .

Transplanting seedlings from nursery to field, .
$\$ 400$ per acre.

520 per 1,000 trees.

550 per acre ( 6 by 6 feet planting).

Improvement thinnings: -

Among planted trees, . . . 600 per acre.

In original timber stands, . . . 2000 per acre.

Fire protection: -

Clearing marginal fire guard 40 feet wide, .

Maintaining marginal fire guard,

Clearing and grading forest roads 15 feet wide,

Maintaining forest roads,

Maintaining fire patrol, .

15000 per mile.

2700 per mile per year.

12000 per mile.

800 per mile per year.

9500 per year.

Reforestation. - Summary of Costs (Wage Rate, $\$ 1.75$ per Eighthour Day).

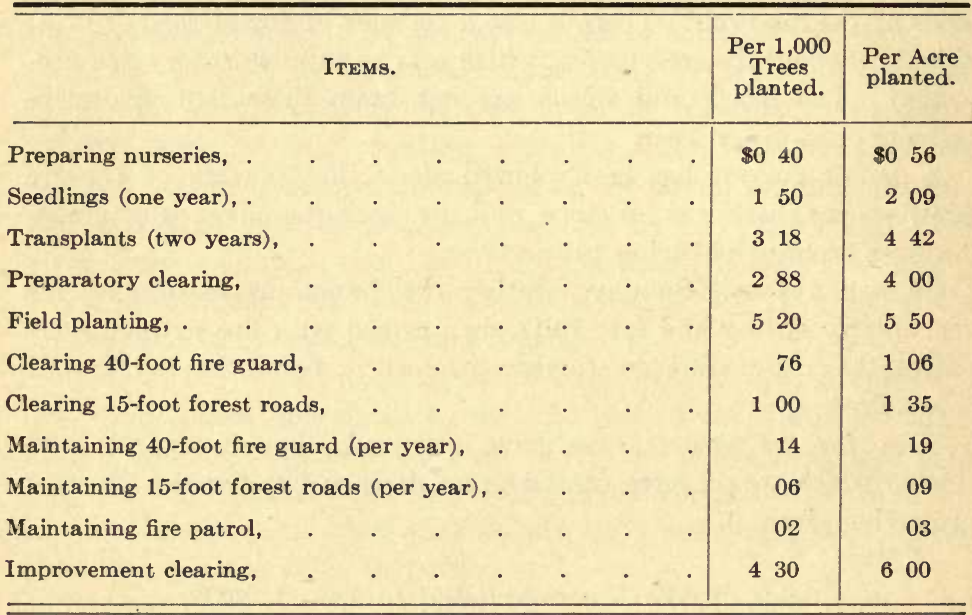

The foregoing table shows that it costs $\$ 14.92$ per 1,000 trees, or $\$ 18.98$ per acre (1,390 trees per acre), to raise the trees from seed, prepare, plant and protect the lands planted through the time of the final planting in the field; that it costs $\$ 0.22$ and $\$ 0.31$ per year respectively to maintain efficient fire protection; that it costs $\$ 4.30$ and $\$ 6$ respectively for an improvement thinning, which will probably have to be made twice during the first ten years, after which time the trees should care for themselves.

Yours very truly,

Henry H. Sprague, Chairman.

E. R. B. Allardice, superintendent in charge Wachusett department; DeXter BRACKETT, ehief engineer of water works. 


\section{Assistants.}

The assistants and employees of the State Forester have practically remained the same throughout the year, and it is a pleasure to compliment them on their fidelity and earnest endeavors in promoting and advancing the State work.

Mr. H. O. Cook, M.F., has done valiant service, particularly in technological lines, as contained in the publication "Mensuration of White Pine," in numerous examinations, etc.

Mr. R. S. Langdell, who has charge of the nursery work and is assisting greatly in the reforestation work, is ever hustling and giving splendid satisfaction, as the nursery and reforestation reports show.

\section{Expenditures and Receipts.}

In accordance with section 6 of chapter 409 of the Acts of 1904, as amended by the Acts of 1907, chapter 473, section 2, the following statement is given of the expenditures for the year ending Nov. 30, 1908:-

Salaries of assistants - $\$ 3,31855$

Travelling expenses (not included in co-operative fund),

Printing,

Postage,

71199

Express,

17540

Instruments,

1134

Miscellaneous,

8925

Nursery,

Balance unexpended,

6377

Total appropriation,

$\$ 10,00000$

Reforestation Account.

Seedlings,

$\$ 3,49579$

Express,

Travelling,

6135

Land, .

75900

Tools, .

8258

$\$ 4,996 \quad 45$

Balance unexpended, 
There was realized from the sale of seedlings $\$ 578.55$, and for seeds $\$ 74.50$, total $\$ 653.05$, which amount has been turned over to the Treasurer and Receiver-General; there was also received from the sale of publications $\$ 153.83$, which has also been turned in to the Treasurer and Receiver-General, making a grand total of $\$ 806.88$. If to this amount is added the amounts unexpended, $\$ 67.32$, we have $\$ 874.30$ as a credit for the year.

In accordance with section 5 of the above-named chapter, the following statement is given of the receipts for travelling and subsistence:-

\section{Lectures.}

Jamaica Plain Unitarian Church, Jamaica Plain, . $\$ 102$ Fitchburg Merchants' Board of Trade, Fitchburg, . The Thursday Club, Brookline, . . . . . . 55 Merchants' Association, Pittsfield, . . . . . 1050 North Adams Merchants' Association, North Adams, . 991 Women's Club, Clinton, . . . . . . 200 Farmers' Institute, Ashfield, . . . . . . $\quad .970$ Worcester Grange, Worcester, . . . . . $\quad$. 300 Farmers' Club, Franklin (paid by club).

Wellesley and Needham Farmers' and Mechanics' Club, Wellesley,

Winchendon Citizens, Winchendon, . . . . $\quad$. 500

State Board of Education, Lunenburg,. . . . . 493

Bridgewater Commercial Club, Bridgewater, . . $\quad$. 350

Waban Women's Club, Waban, . . . . . . -

Pomona Grange, Foxborough, . . . . . . 225

Women's Club, Wellesley Hills, . $\quad$. $\quad$. $\quad$. $\quad 56$

Institute of Technology, Boston, . $\quad$. $\quad$. $\quad . \quad$. 85

Warren Grange, Warren, . . . . . . $\quad 480$

Village Improvement Society, Marion, . . . . 250

Women's Club, Lynn, . . . . . . . 50

Yarmouth Camp Meeting, Yarmouth, . . . . 300

Cochituate Grange, Cochituate, . . . . . . 100

Springfield Pomona, Wilbraham, . . . . . $\quad$. 475

Beverly Improvement Society, Beverly, . . . . 100

Sunderland Grange, Sunderland, . . . . . $\quad$. 450

Farmers' Association, Upton, . . . . . . 250

Westwood Grange, Westwood, . . . . . . 297

Board of Trade, East Bridgewater, . . . . . . 200

Pomona Grange, Berlin, . . . . . . . 250

Pomona Grange, Westfield, . . . . . $\quad$. 550

South Weymouth Grange, South Weymouth, . . $\quad 75$ 
Marlborough Grange, Marlborough,

Beacon Club, Waban,

Women's Club, Norwood, .

A list of the visits made, the area of woodland involved and the receipts for expenses are as follows:-

Examinations of Woodlands.

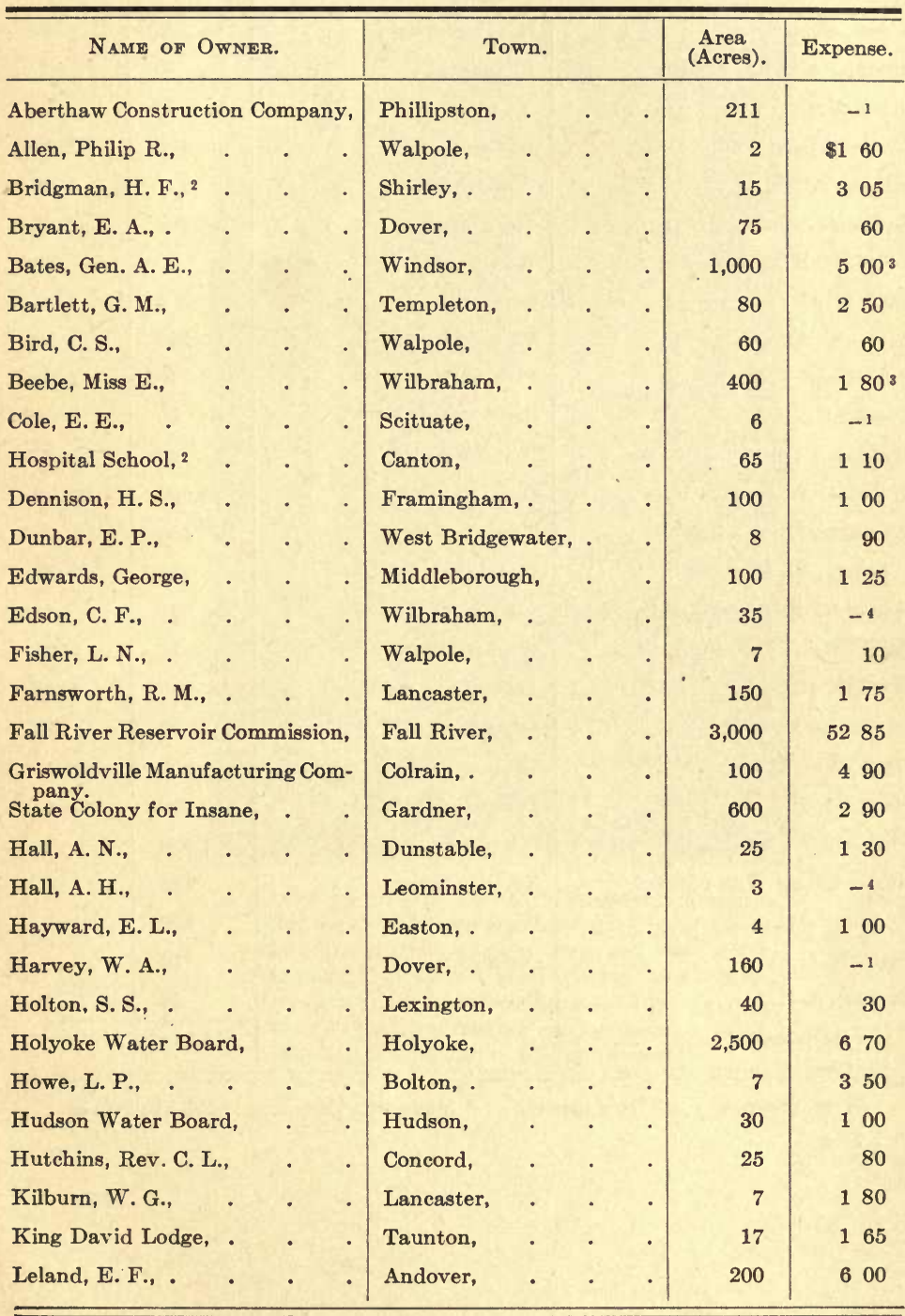

1 Paid by owner. 
Examinations of Woodlands - Concluded.

\begin{tabular}{|c|c|c|c|c|c|c|}
\hline NAME OF OWNER. & & & Town. & & $\begin{array}{c}\text { Area } \\
\text { (Acres). }\end{array}$ & Expense. \\
\hline Leominster Water Board, . & & & Leominster, . & • & 40 & $\$ 170$ \\
\hline Lyman, R. W., & . & & Belchertown, . & . & 50 & $100^{1}$ \\
\hline Means, Rev. O. W., . & - & • & Brookfield, & $\therefore$ & 250 & 270 \\
\hline Medfield Insane Asylum, . & - & • & Medfield, & . & - & 110 \\
\hline Payson, W. E., & - & • & Norton, . & · & 3 & 120 \\
\hline Pease, Miss Laura, & - & • & Middleborough, & - & 25 & -2 \\
\hline Plymouth Water Board, & - & & Plymouth, & : & 40 & -2 \\
\hline Randall, C. A., & . & • & North Dana, . & . & 30 & -2 \\
\hline Rutland Sanatorium, & . & & Rutland, & . & 100 & 210 \\
\hline Seaver, Allyn, . & - & • & Wilbraham, • & - & 127 & $180^{1}$ \\
\hline Sedgwick, Alexander, & - & & Stockbridge, . & . & 300 & $600^{1}$ \\
\hline Snow, R. K., . & . & & Wayland, & . & 30 & 60 \\
\hline Stevens, Chas., & - & • & Sudbury, & - & 5 & 125 \\
\hline Stone, C. A., . & - & • & Plymouth, & . & 200 & 150 \\
\hline Symmington, R. B., ${ }^{8}$ & . & & Plymouth, & . & 10 & 320 \\
\hline Thayer, R. P., . & - & • & South Hadley, & - & 80 & $200^{1}$ \\
\hline Walpole High School, & - & & Walpole, & . & 20 & -2 \\
\hline Westfield Water Board, & - & & Granville, & . & 1,000 & 2000 \\
\hline Worcester Insane Colony, . & & & Grafton, & - & 500 & 170 \\
\hline Whitney, W. M., & . & & Winchendon, . & - & 175 & 265 \\
\hline School for Feeble-minded, & & & Waltham, & . & 45 & -2 \\
\hline School for Feeble-minded, & & & Wrentham, & . & 15 & 120 \\
\hline Wyman, H. A., & . & & Lakeville, & - & 400 & 160 \\
\hline Lawrence, Dr., & . & • & Lexington, & - & 20 & 40 \\
\hline Dean, Wm. M., & . & & Taunton, & . & 200 & -2 \\
\hline Sharp, A. R., . & . & & Taunton, & - & 600 & -1 \\
\hline Pittsfield Water Board, & . & & Pittsfield, & - & 1,500 & -1 \\
\hline North Adams Water Board & & & North Adams, & . & 125 & -6 \\
\hline Prince, F. H., . & 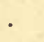 & & Wenham, & . & 800 & -1 \\
\hline Prescott, C. W., & - & & Concord, & . & 70 & -4 \\
\hline Burgess, J. K., & . & & Dedham, & - & 50 & -4 \\
\hline Total area, & - & & - & - & 15,842 & - \\
\hline
\end{tabular}




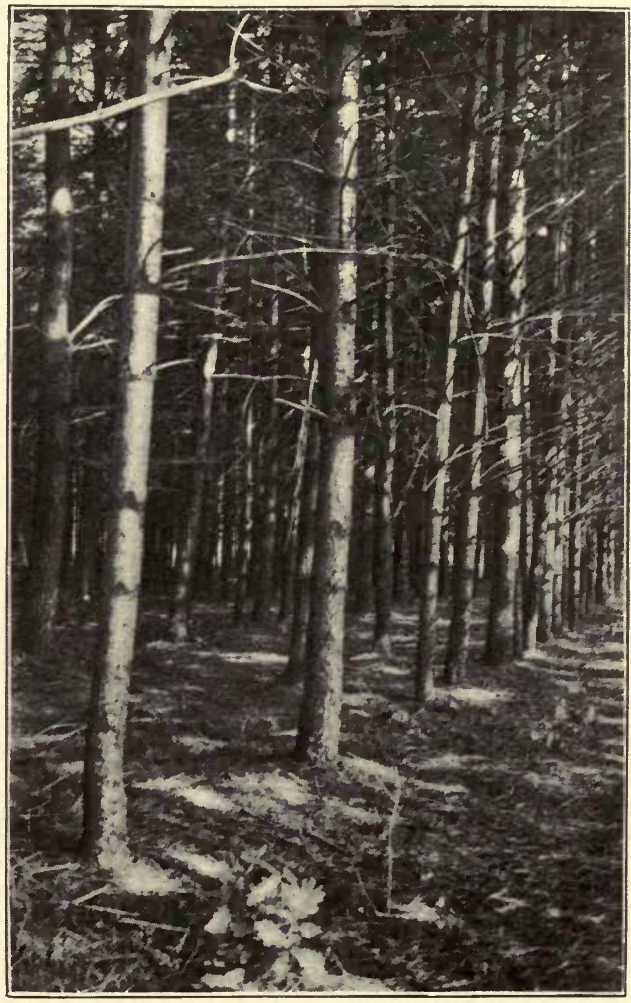

A Stand of White Pine at Sudbury, Mass. This was a field only partly planted by filling in the blank or open spaces when young; now about thirty-eight years old, and estimated to cut 38,000 feet B. M. per acre. One thousand feet per year of white pine is a fair return from cheap lands. Stumpage is worth $\$ i$ to $\$ 10$ per thousand. 

What the General Court is asked to consider at Present.

I. To amend the Reforestation Law, so that the State Forester may not be limited to purchasing Forty Acres in Any One Tract.

While, of course, the purpose of the law in stipulating the number of acres was to spread the work out broadly and make it an object lesson of educational value, nevertheless there are often many tracts that exceed this acreage, and it is but natural that the whole tract should be handled at the same time, and thereby much more economically. Where a few acres overruns the stipulated number, it requires an extra survey, and adds greatly to the expense as well in making out the transfer papers. This amendment would be of great assistance in the practical working out of this law.

\section{A State Forest Survey.}

To authorize a forest survey of the State, in order to determine just what lands should be retained in forests, as an economic factor of the State's conservation policy. With a definite knowledge of conditions mapped out, the State Forester will be greatly aided in the work of reforestation, and have a guide to future endeavor in State work. The survey could be carried out in connection with the workingplans department of the State Forester's office, by simply appropriating a certain amount for employing assistance to do the work. Another way of handling the project would be for the State to pay one-half of the expense of such a survey, provided the counties pay one-half. This work need not be accomplished in one year, but taken up in a systematic way, spending only a nominal sum each year until it is finished.

Our people realize the great importance of conserving the forests in the White Mountains and southern Appalachians, and they undoubtedly recognize equally the importance of conserving the forests within our own State, although they are not on so large a scale. 


\section{Uniform Forestry Legislation.}

It was the consensus of opinion, as the result of the first New England conference called by the Governors of the New England States, that much mutual benefit could come through uniform legislation. Through a call by the Massachusetts State Forester, the New England State Forestry officials met at the State House, Boston, on December 4, and decided to make the following general recommendations for consideration by their respective State Legislatures:-

(a) Resolved, That the cost of extinguishing fires known to be set by railroads shall be paid for by said railroad corporations.

(b) Resolved, That when forest fires are caused by individuals, the individuals causing said fires shall be liable for all expense of their extinguishment.

(c) Resolved, That it is the opinion of the committee that the present Massachusetts forest fire law relative to giving permits for the burning of brush and setting of fires out of doors should be adopted for all the States.

(d) Resolved, That we believe in legislation to regulate the management of forest lands, and that a permit be required by operators of portable mills from the State forest officials.

(e) Resolved, That there should be a law in each State, similar to the Vermont law, authorizing the Governor to issue a proclamation, when it is thought advisable by the State forest official, prohibiting sportsmen and others from traversing the woods unnecessarily.

( $f$ ) Resolved, That there should be definite understandings with the railroads and State forestry officials as to the dangerous sections of the railroad lines traversing the respective States, so that patrols by the railroads may be established whenever it is thought advisable by the State.

(g) Resolved, That there should be a law to regulate the taking of firearms into the woods during the closed season on game.

\section{Increased Appropriation needed.}

The State Forester feels it none other than his duty to ask for an increased appropriation for his work this coming year.

If examined carefully, it can be shown that the expenditure for reforestation and nursery work, while in itself an expenditure by the State, must ultimately come back to the 
State treasury with interest. This, therefore, eliminates as a real out-go from the State treasury fully one-half of the annual appropriation made for this office.

We are convinced that the enactments passed in recent years are proving their value. Now that we have our corps of 350 forest wardens appointed and in the harness, let us give them every legitimate worthy support possible. With an early convention of the forest wardens, I am sure the results to come from such would be regained financially an hundred fold in a single year. The State Forester could utilize the services of forest wardens in various towns to a great advantage along many mutual lines, were there more funds that would permit it. Where such work is left to the towns, many are likely to be indifferent, while, if awakened by a general current of live endeavor on the part of the State, they catch the spirit and realize the importance of selfpreservation. As soon as we have our forest wardens thoroughly familiar with the great good to be accomplished, they are going to impart its importance to the towns they represent.

As I stated last year, the State Forester hopes to so educate his wardens that they will become in a sense town foresters, who shall keep the importance of forestry and how to perpetuate and manage the same practically directly before the people. With such an organization, when gypsy moths, pine blight, fires, etc., are troublesome, or, on the other hand, when people desire to reforest lands or thin and give proper care to their wood lots, in either case here is a man to whom they may look for advice. Is not the State making an expenditure here that will ultimately bring a great reward?

In establishing workable State forest policies, as in every other new undertaking that requires an expenditure of money, we are inclined to be conservative. When we realize, however, that many of our small towns are paying large sums annually simply for fighting forest fires, which expenditure is a constant drain and too often a total loss, to say nothing about the actual loss in present and future forest products, I am sure that business and thinking men can see that it is simply a losing proposition not to definitely and at 
once spend a few dollars that will make it possible to save millions in the future.

The State Forester could spend to great advantage in the coming year $\$ 25,000$ in systematizing and furthering the forestry interests throughout the Commonwealth. Of this sum, $\$ 10,000$ is already provided for in the reforestation act of last year. The regular appropriation for the running expenses and general work of the State Forester for the past year was $\$ 10,000$; therefore, the appropriation asked for would be an increase of $\$ 5,000$.

\section{Summary of Recommendations.}

(1) That the reforestation law be amended so as not hereafter to limit the purchases of land to 40 -acre tracts.

(2) That a State forest survey be established, and funds for its accomplishment be provided.

(3) That the six resolutions of the New England State forestry officials be considered with a view to their adoption for uniform forestry laws. One recommendation is already in the Massachusetts statutes.

(4) That the appropriation for the State Forester's work be $\$ 25,000$ for this year, $\$ 10,000$ of which is already provided for in the reforestation act.

Respectfully submitted,

F. W. RANE, State Forester. 






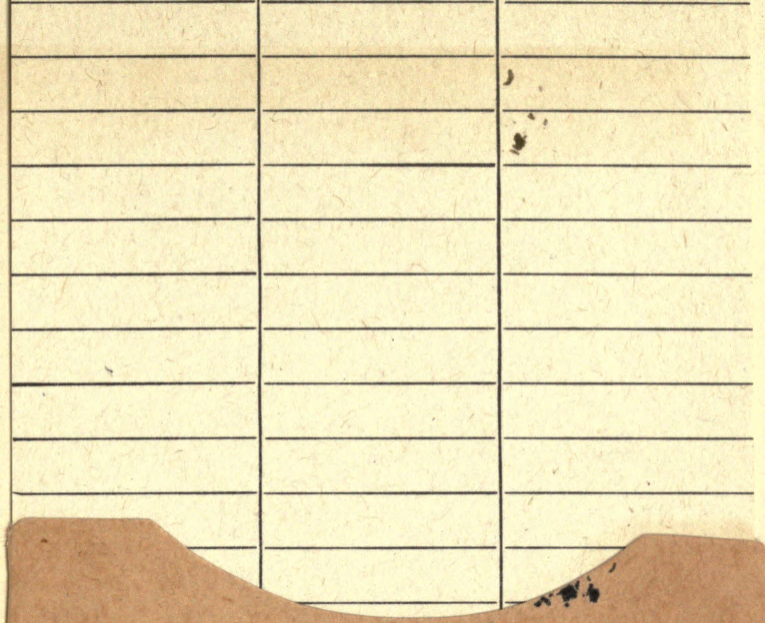

299072

SD 144

$M_{3} P_{3}$

$v, 1$

Anst

UNIVERSITY OF CALIFORNIA LIBRARY. 
